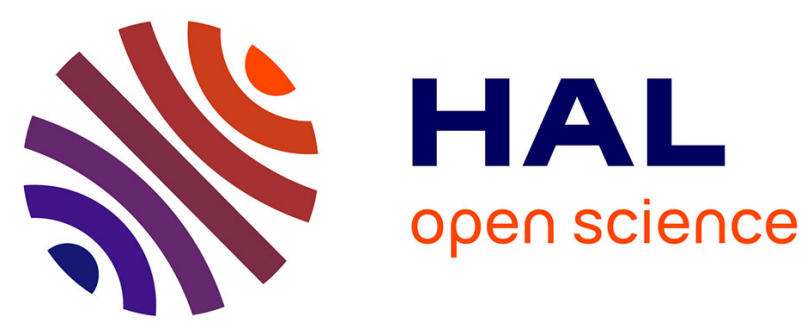

\title{
Rethinking architectural techniques of the Southern Caucasus in the 6th millennium BC: A re-examination of former data and new insights
}

Emmanuel Baudouin

\section{- To cite this version:}

Emmanuel Baudouin. Rethinking architectural techniques of the Southern Caucasus in the 6th millennium BC: A re-examination of former data and new insights. Paléorient, 2019, 45 (1), pp.115-150. 10.4000/paleorient.602 . hal-03150485

\author{
HAL Id: hal-03150485 \\ https://hal.science/hal-03150485
}

Submitted on 9 Jan 2022

HAL is a multi-disciplinary open access archive for the deposit and dissemination of scientific research documents, whether they are published or not. The documents may come from teaching and research institutions in France or abroad, or from public or private research centers.
L'archive ouverte pluridisciplinaire $\mathbf{H A L}$, est destinée au dépôt et à la diffusion de documents scientifiques de niveau recherche, publiés ou non, émanant des établissements d'enseignement et de recherche français ou étrangers, des laboratoires publics ou privés. 


\title{
RETHINKING ARCHITECTURAL TECHNIQUES OF THE SOUTHERN CAUCASUS IN THE $6{ }^{\text {TH }}$ MILLENNIUM BC: A RE-EXAMINATION OF FORMER DATA AND NEW INSIGHTS
}

\author{
E. BAUDOUIN
}

\begin{abstract}
On the basis of new data coming from recent excavations and the re-examination of former publications, a synthesis of architectural techniques in the Southern Caucasus Neolithic is proposed in this article. Using typological and technological analysis, and taking into account building materials, layout techniques and architectural morphology, an attempt has been made to define the technical characteristics of the Early Neolithic communities in this region. The evolution of architectural techniques consists of a complex and slow phenomenon where technical inertia and regional specificities were merged. Although no major technical change occurred throughout the $6^{\text {th }}$ millennium BC, we nevertheless noticed the establishment of distinct construction processes that enabled the identification of well-defined "techno-cultural" groups, leading us to reconsider the model of a unique "Shulaveri-Shomu" culture. Finally, the development of the Caucasian communities' technical advancement is compared with that of the neighbouring Near Eastern ones in order to shed light on the origins of the Neolithic in the Caucasus.
\end{abstract}

Résumé. Sur la base de données inédites provenant de fouilles récentes et de la reprise de publications anciennes, une synthèse des techniques architecturales au Néolithique dans le Sud du Caucase est proposée dans cet article. Par une analyse typologique et technologique, tenant compte des matériaux de construction, des techniques de mise en xuvre et de la morphologie des bâtiments, on cherche à définir les caractéristiques techniques des premières communautés du Néolithique dans la région. L'évolution des techniques architecturales représente un phénomène complexe et lent où se mêlent inertie technique et particularismes régionaux. Si aucune évolution technique majeure n'est avérée durant cette période, on peut néanmoins distinguer une variété dans les procédés de construction qui invite à caractériser des ensembles "techno-culturels » bien marqués et permettent de reconsidérer le modèle d'une culture unique, celle de «Shulaveri-Shomu». Enfin, le développement des techniques des communautés du Caucase est comparé à celui des communautés voisines du Proche-Orient afin d'apporter de nouveaux éléments quant à l'origine de la néolithisation du Caucase.

Keywords. Caucasus, Shulaveri-Shomu, Aratashen, Kültepe, Kamiltepe, Neolithic, earthen material, architecture, sedentary way of life Mots-clés. Caucase, Shulaveri-Shomu, Aratashen, Kültepe, Kamiltepe, Néolithique, matériaux en terre, architecture, sédentarité

The first discoveries of the $6^{\text {th }}$ millennium $\mathrm{BC}$ Neolithic communities in the Southern Caucasus were made in the middle of the $20^{\text {th }}$ century at Kültepe, Nakhichevan (Azerbaijan; see Abibullaev 1959). At this site, a complete Halaf vessel was found, thus raising for the first time the issue of the relationship between the Southern Caucasus and contemporary Mesopotamian communities.
A decade later, excavations were carried out almost simultaneously in the Middle Kura Valley, Azerbaijan, and in the Kvemo-Kartli Plain, Georgia, and a previously unknown culture, Shomu-Shulaveri, was identified (Dzhavakhishvili and Dzhaparidze 1975; Kiguradze 1986; Narimanov 1987; Kushnareva 1997). Later, excavations in the Ararat Plain (Armenia) at Aknashen-Khatunarkh yielded the archaeological 
remains of a contemporary occupation in the south of the Lesser Caucasus, which was considered as a regional variant of the Shulaveri-Shomu culture ${ }^{1}$ (hereafter SSC; Badalyan and Harutyunyan 2014).

As a result of these discoveries, several issues on the origins of the SSC and more generally on the Neolithisation process in this region were raised, and three main hypotheses were confronted (Chataigner et al. 2014; Sagona 2018: 85-86):

1. Independent and local evolution. The Chokh site, on the north-east side of the Great Caucasus (fig. 1), testifies to the progressive development of domestication from the $7^{\text {th }}$ millennium BC Mesolithic levels (Amirkhanov 1987) ${ }^{2}$. Likewise, at Darkveti (level IV, $7^{\text {th }}$ millennium BC), on the eastern fringe of West Georgia, the excavators reported the discovery of domestic species (Niebieridze 1978). However, in both cases, there was no evidence of a link existing between these Mesolithic and the Neolithic communities in the Kura and Araxes Valleys;

2. Cultural interactions (mainly consisting of exchanges of traditional craftsmanship) between Syro-Mesopotamian communities (Hassuna, Samarra, Halaf) and those of the Southern Caucasus (Kiguradze 1986; Kushnareva 1997);

3. "Colonisation" by the Syro-Mesopotamian Neolithic communities (Abibullaev 1959; Narimanov 1987).

With the resumption of research since the beginning of the $2000 s^{3}$ in the Middle Kura Valley (Mentesh Tepe, Göy Tepe, Haci Elamxanlı Tepe and Kiçik Tepe), the Kvemo-Kartli Plain (Aruchlo and Gadachrili Gora), the Karabagh Plain (Ismail Tepe) and the Ararat Plain (Aratashen, Aknashen-Katunarkh and Masis Blur), the time has come to verify these hypotheses. Furthermore, the identification of contemporary sites in the Mil Plain has brought to light yet another culture, that of the Kamiltepe (Helwing and Aliyev 2012, 2017).

1. For convenience, we will use the term "Shulaveri-Shomu culture" (SSC), but the terms "Shomutepe" (Narimanov 1986), "Shulaveri-Shomutepe" (Kiguradze 1986) or "Aratashen-Shulaveri-Shomutepe" (Chataigner et al. 2014; Badalyan and Harutyunyan 2014) are also used in some publications.

2. It should be noted that the stratigraphic succession seems to be interrupted, these levels perhaps being separated by a hiatus of Neolithic levels (Lombard and Chataigner 2004: 69; Lyonnet et al. 2016: 181). See also Chataigner et al. 2014: 11.

3. See the following bibliography: Aratashen (Badalyan et al. 2007; Arimura et al. 2010), Aknashen-Katunarkh (Badalyan et al. 2007; Badalyan and Harutyunyan 2014), Aruchlo (Hansen et al. 2007; Hansen and Mirtskhulava 2012; Hansen and Ullrich 2017), Gadachrili Gora (Hamon et al. 2016), Göy Tepe (Guliyev and Nishiaki 2014; Nishiaki et al. 2015a), Haci Elamxanlı Tepe (Nishiaki et al. 2015b), Masis Blur (Martirosyan-Olshansky et al. 2013) and Mentesh Tepe (Lyonnet et al. 2012; Lyonnet et al. 2016; Lyonnet et al. 2017).
The model of a widely shared Neolithic culture in the South Caucasus (Chataigner et al. 2014: 11) is based on the almost simultaneous adoption of a sedentary way of life ${ }^{4}$ with a farming and animal herding economy from the beginning of the $6^{\text {th }}$ millenniumBC. However, recent researchon the architectural variability among these communities argues for the existence of at least four specific techno-cultural entities ${ }^{5}$, each of which is located in a well circumscribed spatial area: SSC, in the Kvemo-Kartli Plain, the Middle Kura Valley and the Karabagh Plain; Aratashen culture (hereafter AC), in the Ararat Plain; Kültepe, in the Nakhichevan; and Kamiltepe, in the MilPlain.

The purpose of this article is to precise our knowledge about architecture in the Neolithic Southern Caucasus by focusing on the architectural techniques used (e.g., building materials, layout techniques and morphology of the buildings). Finally, on the basis of this data, we will try to define both the interrelationships between the Caucasian communities and their external relations with other cultures outside of this area during the Neolithic.

\section{REGIONAL SETTINGS AND CULTURAL SEQUENCES}

The Southern Caucasus is bounded on the west by the Black Sea, on the north by the Greater Caucasus mountains, on the east by the Caspian Sea, on the south-east by the Kara Dag and Talysh mountains and on the south-west by the Eastern Taurus (fig. 1).

Palynological studies show important climatic changes at the beginning of the Holocene. From 9000 to 8000 BP (ca. 8000$7000 \mathrm{BC}$ ), a warming of the climate led to the emergence of wetlands in the valleys south of the Lesser Caucasus (Araxes Valley) which could have favoured the onset of farming in the region. Geomorphological research demonstrates fluctuations of the Caspian Sea level and its impact on the formation of the alluvial terraces of the Kura River and its tributaries. These fluctuations had a "retroactive impact" (Ollivier et al. 2016: 80) on landscape changes and alluvial terrace organisation and influenced the choice of human settlement locations, as demonstrated by the location of most Neolithic settlements in the alluvial fans of the Kura River tributaries.

4. About the practice of semi-transhumance, see Nishiaki et al. 2018.

5. The notion of "technical group" comes from A. Leroi-Gourhan (1945: 367368) and defines the set of technical characteristics specific to a given group. Nevertheless, for convenience and in order to avoid any confusion, we will use the notion of "culture" as it is defined in archaeology (Monge and Marquis 2008: 141). 

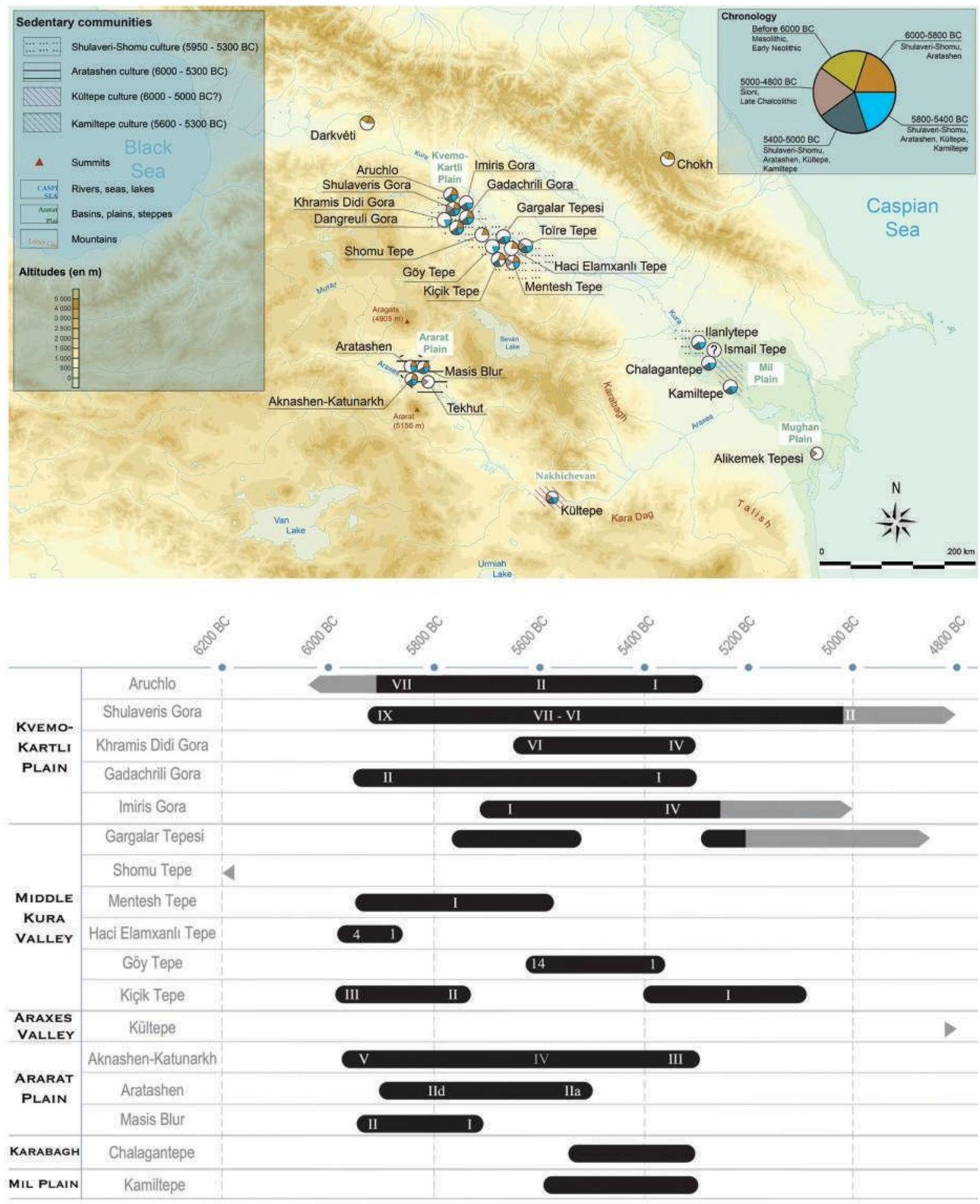

Fig. 1 - General map of the Southern Caucasus with cultural entities, chronology and sites mentioned in the text (E. Baudouin). In grey, inconsistent chronological data. 


\section{THE SHULAVERI-SHOMU CULTURE (SSC)}

The chronological sequence of the SSC spans through almost the entire $6^{\text {th }}$ millennium BC, $c a$. 6000-5300 BC. Recent excavations in the Kvemo-Kartli Plain and in the Middle Kura Valley have provided the earliest dates for this culture, at the beginning of the $6^{\text {th }}$ millennium BC (table 1).

T. Kiguradze was the first to propose an internal phasing of the SSC (phases I to V) in Eastern Georgia (Kiguradze 1986). According to him, phase I ceramic material is characterised by a grey-brown coarse mineral-tempered ware with relief decoration, which is replaced in phase II by a vegetal-tempered ware with pink walls and incised decoration.

Recently, the discovery of a small number of pottery sherds, of which the painted ones are reminiscent of the Samarra or Hassuna cultures at Haci Elamxanl1 Tepe (Nishiaki et al. 2015b: 2), and a grooved stone with a longitudinal groove at Kiçik Tepe, ${ }^{6}$ an artefact otherwise known only in the Middle Euphrates and Zagros foothills from the $11^{\text {th }}$ millennium BC, reinforces the hypothesis of close relationships with the SyroMesopotamian communities ca. $6000 \mathrm{BC}$.

Concerning the architecture, the circular plan, sometimes semi-buried, and the use of plano-convex mud-bricks are often considered to be the architectural markers of the SSC (Lombard and Chataigner 2004: 67).

\section{THE ARATASHEN CULTURE (AC)}

In the Ararat Plain, radiocarbon dates also place the beginning of the $\mathrm{AC}$ around $6000 \mathrm{BC}$ or slightly earlier (table 1).

Again, pottery is very rare in the oldest levels (IId) at Aratashen (Badalyan et al. 2007: 43) and features both mineral and organic temper (Badalyan and Harutyunyan 2014: 163).

At Aknashen-Katunarkh and Aratashen, the finds of imported pottery attributed to the Samarra or Halaf horizons (Arimura et al. 2010: 81; Badalyan and Harutyunyan 2014: 66,175 , fig. 6,176 , fig. $7.3-4$ ) also point to social relationships with the Syro-Mesopotamian communities. The presence of grooved stones with transversal grooves at Aratashen (Arimura et al. 2010: 80-81, fig. 6) confirm this view (Badalyan and Harutyunyan 2014: 164; Chataigner et al. 2014: 18).

In the architecture, circular or oval buildings are built with stacked mud or flat and elongated sun-dried mud-brick shaped by hand (Chataigner et al. 2014: 14).

6. Palumbi G., Guliyev F. and Celilov B. eds. (2018), Mission "Boyuk Kesik", Azerbaïdjan : rapport 2018. Unpublished report, Ministry of Europe and Foreign Affairs (MEAE).

\section{THE KÜLTEPE CULTURE}

Confined to Nakhichevan, the Kültepe culture has thus far only been documented at the eponymous site. ${ }^{7}$ Kültepe, a $9 \mathrm{~m}$ high mound, has a long stratigraphic sequence that seems to span the entire $6^{\text {th }}$ millennium BC (Abibullaev 1959).

The ceramic production is characterised by a red-buff coarse vegetal-tempered ware with few decorations (mostly applied and incised, although a few painted sherds are also known).

In addition to this local production, several elements considered as exogenous have been found in the earliest levels. This is the case of the terracotta spindle whorls and painted Late Halafian pottery typical of the Jezirah cultures from the middle/second half of the $6^{\text {th }}$ millennium BC (Lombard and Chataigner 2004: 76-77).

The architecture seems to present all the characteristics of the Hassuna or Halaf cultures with, in the oldest levels, rectangular buildings built with stacked mud, which were later replaced by circular buildings with stone footings (Lombard and Chataigner 2004: 76).

\section{THE KAMILTEPE CULTURE}

Located in the Mil Plain, the Kamiltepe culture has recently been identified (Aliyev and Helwing 2009; Helwing and Aliyev 2012: 4-58). Excavations and surveys place the first stages of sedentarisation in the region ca. $5600 \mathrm{BC}$ (table 1). Many sites of this culture have been documented as temporary occupations (Ricci et al. 2018).

The ceramic material, mainly chaff tempered, is decorated with painted geometrical motifs, which have little in common with the SSC (Helwing et al. 2017: 4, 7); however, they do present some similarities with Hajji Firuz Tepe in Northern Zagros, near Lake Urmiah (Voigt 1983).

In terms of the architectural evidence, Kamiltepe stands out due to the construction of an imposing mud-brick platform, the use of mud-bricks shaped by hand and specific layout techniques (Helwing and Aliyev 2017: 16). A nearby site, MPS 4, presents a circular buried architecture made of mud bricks similar to that of the SCC (Helwing and Aliyev 2017: 8-10).

7. Excavations resumed in 2012, under the direction of C. Marro, R. Berthon and V. Bakhshaliyev.

8. BohENER U. and SchYLE D. (2006), Radiocarbon CONTEXT database 2002-2006 [URL: http://context-database.uni-koeln.de/]. 
Table 1 -Radiocarbon dates for the Neolithic sites in Southern Caucasus (E. Baudouin).

\begin{tabular}{|c|c|c|c|c|c|c|c|}
\hline Site & Level & Context & $n^{\circ} \mathrm{Lab}$ & Date BP & Cal. BC (1 s) & Cal. BC (2s) & Bibliographical references \\
\hline \multirow{20}{*}{$\begin{array}{l}\text { Aknashen- } \\
\text { Katunarkh }\end{array}$} & \multirow{4}{*}{$\begin{array}{c}\mathrm{V} \\
\text { (lower level) }\end{array}$} & Trench A. UF 12 & LY-13665 & $6920 \pm 55$ & $5871-5734$ & $5986-5661$ & \multirow{20}{*}{$\begin{array}{c}\text { Badalyan et al. } 2010: \\
212, \text { table } 1\end{array}$} \\
\hline & & Trench A. UF 11 & AA-68561 & $7035 \pm 69$ & $5991-5846$ & $6085-5717$ & \\
\hline & & Trench A. UF 10/F5 & AA-68560 & $6930 \pm 44$ & $5868-5743$ & $5984-5676$ & \\
\hline & & Trench A. UF 10 & UGAMS 2292 & $6900 \pm 50$ & $5837-5731$ & $5980-5644$ & \\
\hline & \multirow{11}{*}{ IV } & Trench 5. UF 8a & UGAMS 5805 & $6970 \pm 25$ & $5893-5810$ & $5981-5740$ & \\
\hline & & Trench 1. UF 8 & UGAMS 5802 & $6940 \pm 30$ & $5870-5760$ & $5975-5725$ & \\
\hline & & Trench A. UF7 & AA-68559 & $6868 \pm 40$ & $5800-5712$ & $5888-5641$ & \\
\hline & & Trench 5. UF 7a & UGAMS 4081 & $6720 \pm 30$ & $5662-5621$ & $5721-5555$ & \\
\hline & & Trench 2. UF 7a F.7 & UGALS 2821 & $6740 \pm 50$ & $5707-5623$ & $5766-5515$ & \\
\hline & & Trench 4. UF 7a, str. 8 & UGAMS 5803 & $6800 \pm 30$ & $5718-5667$ & $5756-5624$ & \\
\hline & & Trench A. UF 8 & UGAMS 2293 & $6550 \pm 50$ & $5550-5476$ & $5629-5367$ & \\
\hline & & Trench 3. UF 7b & UGAMS 4079 & $6640 \pm 30$ & $5618-5556$ & $5636-5486$ & \\
\hline & & Trench 3. UF 7b & UGAMS 4080 & $6590 \pm 30$ & $5558-5490$ & $5620-5477$ & \\
\hline & & Trench 6. UF 7a & UGAMS 4082 & $6560 \pm 30$ & $5531-5482$ & $5617-5471$ & \\
\hline & & Trench 4. UF 8b & UGAMS 5804 & $6600 \pm 25$ & $5608-5513$ & $5621-5481$ & \\
\hline & \multirow{5}{*}{$\begin{array}{c}\text { III } \\
\text { (upper level) }\end{array}$} & Trench I. UF 6 & Poz-22745 & $6910 \pm 40$ & $5837-5739$ & $5975-5671$ & \\
\hline & & Trench 4. UF 6 & Poz-22747 & $6790 \pm 40$ & $5718-5659$ & $5796-5569$ & \\
\hline & & Trench 6. UF 6b & UGAMS 2820 & $6690 \pm 50$ & $5658-5560$ & $5723-6486$ & \\
\hline & & Trench 3. UF 6a & Poz-22746 & $6420 \pm 40$ & $5468-5367$ & $5487-5299$ & \\
\hline & & Trench A. UF 6 & LY-13664 & $6350 \pm 70$ & $5465-5228$ & $5511-5054$ & \\
\hline \multirow{6}{*}{ Aratashen } & \multirow{3}{*}{$\begin{array}{c}\text { Ild } \\
\text { (lower level) }\end{array}$} & & AA-64176 & $6821 \pm 46$ & & $5791-5631$ & \multirow{6}{*}{ Badalyan et al. 2007: 40, table 1} \\
\hline & & & AA-64178 & $6866 \pm 49$ & & $5848-5658$ & \\
\hline & & & AA-64177 & $6913 \pm 49$ & & $5905-5711$ & \\
\hline & $\mathrm{Ilb}$ & & AA-64175 & $6948 \pm 73$ & & $5988-5713$ & \\
\hline & \multirow{2}{*}{$\begin{array}{c}\text { Ila } \\
\text { (upper level) }\end{array}$} & & Ly-2269 & $6660 \pm 60$ & & $5663-5481$ & \\
\hline & & & Ly-2268 & $6820 \pm 55$ & & $5811-5627$ & \\
\hline \multirow{16}{*}{ Aruchlo } & & AR10B066-298 & Hd-12879 & $6919 \pm 30$ & $5836-5748$ & $5877-5731$ & \multirow{11}{*}{$\begin{array}{l}\text { Hansen and Mirtskhulava 2012: } \\
\text { 85, table } 19\end{array}$} \\
\hline & & AR05A108a & $B \ln -5854$ & $6850 \pm 35$ & $5759-5674$ & $5835-5661$ & \\
\hline & & AR11U045-359/360 & MAMS-14734 & $6844 \pm 26$ & $5744-5676$ & $5775-5665$ & \\
\hline & & AR11AA005-369 & MAMS-14736 & $6814 \pm 27$ & $5723-5673$ & $5736-5645$ & \\
\hline & & AR11AA009-386 & MAMS-14738 & $6800 \pm 26$ & $5716-5669$ & $5716-5669$ & \\
\hline & & AR11AA008-370 & MAMS-14737 & $6788 \pm 27$ & $5713-5663$ & $5724-5639$ & \\
\hline & & AR11AA007-364 & MAMS-14735 & $6784 \pm 26$ & $5712-5661$ & $5722-5638$ & \\
\hline & & AR07M013-181 & Hd-28506 & $6650 \pm 28$ & $5621-5559$ & $5629-5530$ & \\
\hline & & AR07K044-191 & Hd-28505 & $6591 \pm 22$ & $5557-5491$ & $5611-5485$ & \\
\hline & & AR06C021-151 & $B \ln -5949$ & $6451 \pm 40$ & $5474-5378$ & $5482-5341$ & \\
\hline & & AR06D013-146 & Bln-5950 & $6369 \pm 46$ & $5464-5306$ & $5472-5229$ & \\
\hline & 7 & & TB-300 & $7135 \pm 70$ & & $\begin{array}{l}6250-5645 \\
6140-5860^{*}\end{array}$ & \multirow{3}{*}{$\begin{array}{l}\text { Kiguradze 1986: } 112 \text {, table 5; } \\
\text { Bohener and Schylde } 2006^{*} \\
\text { (see note } 8)\end{array}$} \\
\hline & \multirow{2}{*}{3} & & TB-309 & $6770 \pm 65$ & & $\begin{array}{l}5820-5400 \\
5780-5580^{*}\end{array}$ & \\
\hline & & & TB-331 & $6365 \pm 140$ & & $\begin{array}{l}5435-5180 \\
5620-4980^{*}\end{array}$ & \\
\hline & 2 & & TB-277 & $6765 \pm 60$ & & $\begin{array}{l}5805-5410 \\
5770-5570^{*}\end{array}$ & $\begin{array}{c}\text { Goridze 1979: 425; } \\
\text { Bohener and Schylde 2006* }\end{array}$ \\
\hline & 1 & & TB-92 & $6525 \pm 60$ & & $\begin{array}{c}5560-5280 \\
5620-5340^{*}\end{array}$ & $\begin{array}{c}\text { Chelidze 1979: } 31 \\
\text { Bohener and Schylde } 2006^{*}\end{array}$ \\
\hline Chalagantepe & & $2.4 \mathrm{~m}$ deep & TB-318 & $6507 \pm 60$ & & $\begin{array}{c}5420-5215 \\
5550-5260^{*}\end{array}$ & $\begin{array}{l}\text { Kiguradze 1986: } 112, \text { table 5; } \\
\text { Bohener and Schylde } 2006^{*}\end{array}$ \\
\hline \multirow{4}{*}{ Gadachrili Gora } & \multirow{2}{*}{$\begin{array}{c}\text { II } \\
\text { (lower level) }\end{array}$} & Charcoal & LTL13000A & & & $5970-5720$ & \multirow{4}{*}{ Hamon et al. 2016: 158, fig. 4} \\
\hline & & Seed & LTL13223A & & & $5850-5650$ & \\
\hline & 1 & Charcoal & OS-63262 & & & $5640-5300$ & \\
\hline & (upper level) & Seed & OS-63260 & & & $5860-5700$ & \\
\hline \multirow{2}{*}{ Gargalar Tepesi } & & $\begin{array}{l}\text { Fireplace dug } \\
\text { into virgin soil }\end{array}$ & LE-1083 & $6750 \pm 60$ & & $\begin{array}{l}5785-5400 \\
5760-5560^{*}\end{array}$ & \multirow{2}{*}{$\begin{array}{l}\text { Narimanov 1977: 57; } \\
\text { Bohener and Schylde 2006* }\end{array}$} \\
\hline & & $\begin{array}{l}\text { Fireplace located } 2 \mathrm{~m} \\
\text { upper the virgin soil }\end{array}$ & LE-1084 & $6125 \pm 60$ & & $\begin{array}{c}5230-4945 \\
5280-4880^{*}\end{array}$ & \\
\hline
\end{tabular}




\begin{tabular}{|c|c|c|c|c|c|c|c|}
\hline Site & Level & Context & $n^{\circ}$ Lab & Date BP & Cal. BC (1 s) & Cal. BC (2 s) & Bibliographical references \\
\hline \multirow{36}{*}{$\begin{array}{l}\text { Göy Tepe } \\
\text { (Main Trench) }\end{array}$} & \multirow{2}{*}{$\begin{array}{c}14 \\
\text { (lower } \\
\text { level) }\end{array}$} & GOY13 4BIIX-129a & IAAA-132140 & $6700 \pm 30$ & $\begin{array}{l}5645-5565(68.2 \%) \\
5670-5555(95.4 \%)\end{array}$ & $\begin{array}{l}5662-5605(63.6 \%) \\
5596-5560(31.8 \%)\end{array}$ & \multirow{12}{*}{$\begin{array}{l}\text { Nishiaki et al. 2018: } 122 \text {, table } 1 \text {; } \\
\text { Nishiaki et al. 2015a: } 286 \text {, table } 1\end{array}$} \\
\hline & & GOY13 4BIIX-129b & IAAA-132141 & $6690 \pm 30$ & $\begin{array}{l}5640-5565(68.2 \%) \\
5665-5555(95.4 \%)\end{array}$ & $\begin{array}{l}5659-5604(60.4 \%) \\
5596-5560(35.0 \%)\end{array}$ & \\
\hline & 13 & GOY12 4BIIX-124 & IAAA-120686 & $6800 \pm 30$ & $\begin{array}{l}5720-5665(68.2 \%) \\
5735-5640(95.4 \%)\end{array}$ & $5731-5642$ & \\
\hline & \multirow{3}{*}{12} & GOY10 4BIIX-92 & IAAA-120058 & $6730 \pm 30$ & $\begin{array}{l}5665-5620(68.2 \%) \\
5715-5570(95.4 \%)\end{array}$ & $\begin{array}{l}5714-5616(92.4 \%) \\
5584-5571(3.0 \%)\end{array}$ & \\
\hline & & GOY11 4BIIX-109 & IAAA-120684 & $6620 \pm 30$ & $\begin{array}{l}5615-5525(68.2 \%) \\
5625-5490(95.4 \%)\end{array}$ & $5621-5511$ & \\
\hline & & GOY12 4BIIX-113a & IAAA-120685 & $6590 \pm 30$ & $\begin{array}{l}5550-5510(68.2 \%) \\
5560-5490(95.4 \%)\end{array}$ & $\begin{array}{l}5612-5590(11.5 \%) \\
5565-5482(83.9 \%)\end{array}$ & \\
\hline & 11 & GOY11 4BI-116 & IAAA-120068 & $6680 \pm 30$ & $\begin{array}{l}5635-5560(68.2 \%) \\
5660-5540(95.4 \%)\end{array}$ & $5568-5546$ & \\
\hline & \multirow{5}{*}{10} & GOY09 4BIIX-45 & TKa-15171 & $6610 \pm 50$ & $\begin{array}{l}5615-5510(68.2 \%) \\
5625-5480(95.4 \%)\end{array}$ & $5623-5483$ & \\
\hline & & GOY11 4BI-111 & IAAA-120067 & $6610 \pm 30$ & $\begin{array}{l}5615-5515(68.2 \%) \\
5620-5490(95.4 \%)\end{array}$ & $5617-5490$ & \\
\hline & & GOY09 4BIIX-51 & TKa-15175 & $6580 \pm 80$ & $\begin{array}{l}5615-5475(68.2 \%) \\
5645-5370(95.4 \%)\end{array}$ & $5644-5374$ & \\
\hline & & GOY09 4BIIX-50 & TKa-15172 & $6570 \pm 70$ & $\begin{array}{l}5615-5475(68.2 \%) \\
5635-5375(95.4 \%)\end{array}$ & $\begin{array}{l}5632-5462(87.6 \%) \\
5447-5379(7.8 \%)\end{array}$ & \\
\hline & & GOY09 4BIIX-53 & TKa-15174 & $6530 \pm 80$ & $\begin{array}{l}5610-5380(68.2 \%) \\
5625-5340(95.4 \%)\end{array}$ & $5623-5343$ & \\
\hline & \multirow{4}{*}{9} & GOY09 4BIIX-10 & NUTA2-22555 & $6630 \pm 30$ & $\begin{array}{l}5620-5535(68.2 \%) \\
5625-5510(95.4 \%)\end{array}$ & & Nishiaki et al. 2018: 122, table 1 \\
\hline & & GOY11 4BI-84 & IAAA-120066 & $6620 \pm 30$ & $\begin{array}{l}5615-5525(68.2 \%) \\
5625-5490(95.4 \%)\end{array}$ & $\begin{array}{l}5619-5508(91.1 \%) \\
5502-5491(4.3 \%)\end{array}$ & \multirow{11}{*}{$\begin{array}{l}\text { Nishiaki et al. 2018: 122, table 1; } \\
\text { Nishiaki et al. 2015a: 286, table } 1\end{array}$} \\
\hline & & AF06-no8 & UBA-7616 & $6602 \pm 39$ & $\begin{array}{l}5615-5505(68.2 \%) \\
5620-5485(95.4 \%)\end{array}$ & $5617-5484$ & \\
\hline & & GOY09 4BIIX-5 & TKa-15168 & $6400 \pm 50$ & $\begin{array}{l}5470-5320(68.2 \%) \\
5480-5305(95.4 \%)\end{array}$ & $5476-5306$ & \\
\hline & \multirow{4}{*}{8} & AF06-no1 & UBA-7614 & $6575 \pm 39$ & $\begin{array}{l}5555-5480(68.2 \%) \\
5615-5475(95.4 \%)\end{array}$ & $\begin{array}{l}5615-5584(13.5 \%) \\
5571-5476(81.9 \%)\end{array}$ & \\
\hline & & AF06-no4 & UBA-7615 & $6574 \pm 41$ & $\begin{array}{l}5555-5480(68.2 \%) \\
5620-5475(95.4 \%)\end{array}$ & $\begin{array}{l}5616-5584(13.9 \%) \\
5572-5476(81.5 \%)\end{array}$ & \\
\hline & & GOY11 4BI-63 & IAAA-120065 & $6560 \pm 30$ & $\begin{array}{l}5535-5480(68.2 \%) \\
5610-5475(95.4 \%)\end{array}$ & $\begin{array}{l}5608-5593(5.1 \%) \\
5562-5477(90.3 \%) \\
\end{array}$ & \\
\hline & & GOY09 4BII-51 & TKa-15173 & $6450 \pm 70$ & $\begin{array}{l}5485-5355(68.2 \%) \\
5545-5300(95.4 \%)\end{array}$ & $5543-5301$ & \\
\hline & \multirow{2}{*}{7} & GOY09 4BII-21 & TKa-15169 & $6520 \pm 70$ & $\begin{array}{l}5555-5380(68.2 \%) \\
5620-5355(95.4 \%)\end{array}$ & 5617-5357 & \\
\hline & & GOY09 4BII-21 & TKa-15170 & $6410 \pm 70$ & $\begin{array}{l}5470-5335(68.2 \%) \\
5490-5225(95.4 \%)\end{array}$ & $\begin{array}{l}5490-5286(91.0 \%) \\
5273-5226(4.4 \%)\end{array}$ & \\
\hline & 6 & GOY11 3All & IAAA-120063 & $6610 \pm 30$ & $\begin{array}{l}5615-5515(68.2 \%) \\
5620-5490(95.4 \%)\end{array}$ & $\begin{array}{l}5618-5508(90.3 \%) \\
5503-5490(5.1 \%)\end{array}$ & \\
\hline & \multirow{2}{*}{5} & GOY11 4AI & IAAA-120064 & $6470 \pm 30$ & $\begin{array}{l}5480-5380(68.2 \%) \\
5485-5370(95.4 \%)\end{array}$ & $5483-5371$ & \\
\hline & & GOY10 4BI-17 & NUTA2-22554 & $6418 \pm 29$ & $\begin{array}{l}5470-5365(68.2 \%) \\
5475-5330(95.4 \%)\end{array}$ & & Nishiaki et al. 2018: 122, table 1 \\
\hline & \multirow{4}{*}{4} & GOY08 & TKa-14622 & $6575 \pm 35$ & $\begin{array}{l}5550-5480(68.2 \%) \\
5615-5475(95.4 \%)\end{array}$ & $\begin{array}{c}5615-5585(6.2 \%) \\
5570-5482(79.2 \%)\end{array}$ & \multirow{11}{*}{$\begin{array}{l}\text { Nishiaki et al. 2018: } 122 \text {, table } 1 \text {; } \\
\text { Nishiaki et al. 2015a: } 286 \text {, table } 1\end{array}$} \\
\hline & & GOY08 2B & TKa-14623 & $6500 \pm 35$ & $\begin{array}{l}5515-5385(68.2 \%) \\
5530-5370(95.4 \%)\end{array}$ & $5528-5374$ & \\
\hline & & GOY09 2All & TKa-14999 & $6480 \pm 50$ & $\begin{array}{l}5485-5375(68.2 \%) \\
5530-5330(95.4 \%)\end{array}$ & $5528-5338$ & \\
\hline & & GOY09 2AI & TKa-15000 & $6480 \pm 45$ & $\begin{array}{l}5485-5375(68.2 \%) \\
5530-5340(95.4 \%)\end{array}$ & $5526-5356$ & \\
\hline & \multirow{4}{*}{3} & GOY14 1A-3 & IAAA-141122 & $6650 \pm 30$ & $\begin{array}{l}5625-5555(68.2 \%) \\
5635-5525(95.4 \%)\end{array}$ & $5631-5519$ & \\
\hline & & GOY14 1A-1 & IAAA-141120 & $6565 \pm 30$ & $\begin{array}{l}5535-5480(68.2 \%) \\
5610-5475(95.4 \%)\end{array}$ & $\begin{array}{c}5607-5595(4.5 \%) \\
5562-5477(90.9 \%)\end{array}$ & \\
\hline & & GOY14 1A-2 & IAAA-141121 & $6530 \pm 30$ & $\begin{array}{l}5515-5475(68.2 \%) \\
5560-5390(95.4 \%)\end{array}$ & $\begin{array}{l}5558-5467(94.7 \%) \\
5399-5392(0.7 \%)\end{array}$ & \\
\hline & & GOY09 1All & TKa-14998 & $6460 \pm 50$ & $\begin{array}{l}5480-5375(68.2 \%) \\
5510-5320(95.4 \%)\end{array}$ & $5508-5502(0.8 \%)$ & \\
\hline & 2 & GOY14 1B-4 & IAAA-141124 & $6565 \pm 30$ & $\begin{array}{l}5535-5480(68.2 \%) \\
5610-5475(95.4 \%)\end{array}$ & $\begin{array}{c}5607-5595(3.4 \%) \\
5561-5477(91.6 \%)\end{array}$ & \\
\hline & \multirow{2}{*}{$\begin{array}{c}1 \\
\text { (upper } \\
\text { level) }\end{array}$} & GOY14 1B-3 & IAAA-141123 & $6480 \pm 30$ & $\begin{array}{l}5485-5380(68.2 \%) \\
5490-5370(95.4 \%)\end{array}$ & $5486-5372$ & \\
\hline & & GOY14 1B-6 & IAAA-141125 & $6385 \pm 30$ & $\begin{array}{l}5465-5315(68.2 \%) \\
5470-5310(95.4 \%)\end{array}$ & $\begin{array}{l}5486-5400(32.9 \%) \\
5391-5313(62.5 \%)\end{array}$ & \\
\hline
\end{tabular}




\begin{tabular}{|c|c|c|c|c|c|c|c|}
\hline Site & Level & Context & $n^{\circ}$ Lab & Date BP & Cal. BC (1 s) & Cal. BC (2 s) & Bibliographical references \\
\hline \multirow{3}{*}{$\begin{array}{l}\text { Göy Tepe } \\
\text { (sector 97F) }\end{array}$} & & GOY11 97F-13 & IAAA-120061 & $6590 \pm 30$ & $\begin{array}{l}5560-5490(68.2 \%) \\
5615-5480(95.4 \%)\end{array}$ & & \multirow{11}{*}{ Nishiaki et al. 2018: 122, table 1} \\
\hline & & GOY11 97F-hearth & IAAA-120062 & $6410 \pm 30$ & $\begin{array}{l}5470-5360(68.2 \%) \\
5470-5325(95.4 \%)\end{array}$ & & \\
\hline & & GOY11 97F-10 & IAAA-120060 & $6530 \pm 30$ & $\begin{array}{l}5515-5475(68.2 \%) \\
5560-5390(95.4 \%)\end{array}$ & & \\
\hline $\begin{array}{l}\text { Göy Tepe } \\
\text { (sector 96F) }\end{array}$ & & GOY11 96F-5 & IAAA-120059 & $6570 \pm 30$ & $\begin{array}{l}5540-5480(68.2 \%) \\
5610-5475(95.4 \%)\end{array}$ & & \\
\hline \multirow{4}{*}{$\begin{array}{c}\text { Göy Tepe } \\
\text { (sector 93A_2) }\end{array}$} & & GOY11 93A-no1 & IAAA-120056 & $6710 \pm 30$ & $\begin{array}{l}5660-5575(68.2 \%) \\
5705-5560(95.4 \%)\end{array}$ & & \\
\hline & & GOY11 93A-no2 & IAAA-120057 & $6660 \pm 30$ & $\begin{array}{l}5625-5560(68.2 \%) \\
5635-5530(95.4 \%)\end{array}$ & & \\
\hline & & GOY12 93A1-23 & IAAA-120691 & $6620 \pm 30$ & $\begin{array}{l}5615-5525(68.2 \%) \\
5625-5490(95.4 \%)\end{array}$ & & \\
\hline & & GOY12 93A1-13 & IAAA-120690 & $6630 \pm 30$ & $\begin{array}{l}5620-5535(68.2 \%) \\
5625-5510(95.4 \%)\end{array}$ & & \\
\hline \multirow{3}{*}{$\begin{array}{c}\text { Göy Tepe } \\
\text { (sector 92A1) }\end{array}$} & $\begin{array}{c}\text { Bottom } \\
\text { layer }\end{array}$ & GOY13 92Al-18 & IAAA-132143 & $6860 \pm 30$ & $\begin{array}{l}5775-5710(68.2 \%) \\
5810-5665(95.4 \%)\end{array}$ & & \\
\hline & $\begin{array}{l}\text { Middle } \\
\text { layer }\end{array}$ & GOY13 92Al-17 & IAAA-132142 & $6730 \pm 30$ & $\begin{array}{l}5665-5620(68.2 \%) \\
5715-5570(95.4 \%)\end{array}$ & & \\
\hline & $\begin{array}{l}\text { Upper } \\
\text { layer }\end{array}$ & GOY12 92Al-11 & IAAA-120687 & $6590 \pm 30$ & $\begin{array}{l}5560-5490(68.2 \%) \\
5615-5480(95.4 \%)\end{array}$ & & \\
\hline \multirow{13}{*}{$\begin{array}{c}\text { Haci Elamxanlı } \\
\text { Tepe }\end{array}$} & $\begin{array}{c}4 \mathrm{~b} \text { (lower } \\
\text { level) }\end{array}$ & HAJ14 M11-102 & IAAA-141127 & $6025 \pm 30$ & & $5987-5846$ & Nishiaki et al. 2015a: 287, table 2 \\
\hline & \multirow{2}{*}{$4 a$} & HAJ2012 M10-96H & IAAA-120698 & $7080 \pm 30$ & $\begin{array}{l}6003-5974(29.5 \%) \\
5951-5917(38.7 \%)\end{array}$ & $6015-5895(95.4 \%)$ & \multirow{2}{*}{ Nishiaki et al. 2013: 11, table 1} \\
\hline & & HAJ2012 M10-96I & IAAA-120699 & $6950 \pm 40$ & $5885-5783(68.2 \%)$ & $\begin{array}{c}5969-5955(2.7 \%) \\
5907-5739(92.7 \%)\end{array}$ & \\
\hline & \multirow[t]{2}{*}{$3 b$} & HAJ14 L10-122 & IAAA-141126 & $7015 \pm 30$ & & $\begin{array}{l}5990-5837(94.6 \%) \\
5822-5815(0.8 \%)\end{array}$ & \multirow[t]{2}{*}{ Nishiaki et al. 2015a: 287, table 2} \\
\hline & & HAJ14 L11-128 & IAAA-141127 & $7030 \pm 30$ & & $5991-5843$ & \\
\hline & \multirow{3}{*}{ 3a } & HAJ2012 M10-15 & IAAA-120696 & $7070 \pm 30$ & $\begin{array}{l}6001-5974(28.0 \%) \\
5952-5916(40.2 \%)\end{array}$ & $6015-5893(95.4 \%)$ & \multirow{2}{*}{ Nishiaki et al. 2013: 11, table 1} \\
\hline & & HAJ2012 M10-79 & IAAA-120697 & $7060 \pm 30$ & $\begin{array}{l}5992-5970(20.6 \%) \\
5955-5907(47.6 \%)\end{array}$ & $6012-5886(95.4 \%)$ & \\
\hline & & HAJ13 L11-106 & IAAA-132146 & $6990 \pm 30$ & & $\begin{array}{l}5981-5944(17.1 \%) \\
5926-5792(78.3 \%)\end{array}$ & Nishiaki et al. 2015a: 287, table 2 \\
\hline & \multirow{3}{*}{2} & HAJ2012 M10-48 & IAAA-120694 & $6960 \pm 30$ & 5890-5799 (68.2\%) & $\begin{array}{c}5971-5954(3.8 \%) \\
5912-5752(91.6 \%)\end{array}$ & \multirow{2}{*}{ Nishiaki et al. 2013: 11, table1 } \\
\hline & & HAJ2012 M10-68 & IAAA-120695 & $6930 \pm 30$ & $5838-5755(68.2 \%)$ & $5882-5733(95.4 \%)$ & \\
\hline & & HAJ13 L11-22 & IAAA-132145 & $7000 \pm 30$ & & $\begin{array}{l}5983-5939(23.6 \%) \\
5932-5807(71.8 \%)\end{array}$ & Nishiaki et al. 2015a: 287, table 2 \\
\hline & $\begin{array}{c}1 \\
\text { (upper }\end{array}$ & HAJ2012 M10-54 & IAAA-120693 & $7000 \pm 30$ & $\begin{array}{l}5974-5951(19.6 \%) \\
5917-5873(36.8 \%) \\
5863-5846(11.9 \%)\end{array}$ & $\begin{array}{c}5985-5834(92.6 \%) \\
5826-5810(2.8 \%)\end{array}$ & Nishiaki et al. 2013: 11, table 1 \\
\hline & & HAJ13 M11-13 & IAAA-132114 & $6890 \pm 30$ & & $5837-5723$ & Nishiaki et al. 2015a: 287, table 2 \\
\hline \multirow{2}{*}{ Imiris Gora } & \multirow{2}{*}{ IV-I } & Building 9-10 & TB-19 & $6590 \pm 120$ & & $\begin{array}{l}5635-5305 \\
5730-4950^{*}\end{array}$ & $\begin{array}{c}\text { Dzhavakhshvili and Dzhaparidze 1975: } \\
\text { 127; Bohener and Schylde } 2006^{*}\end{array}$ \\
\hline & & Upper level & TB-27 & $6300 \pm 120$ & & $\begin{array}{l}5350-5085 \\
5500-4950^{*}\end{array}$ & $\begin{array}{l}\text { Burchuladze et al. 1976: } 356 ; \\
\text { Bohener and Schylde } 2006^{*}\end{array}$ \\
\hline \multirow{22}{*}{ Kamiltepe } & & KAM09-111/57 & KIA40368 & $6568 \pm 31$ & & $5610-5480$ & \multirow{9}{*}{ Aliyev and Helwing 2009: 38, fig. 21} \\
\hline & & KAM09-307/1 & KIA40371 & $6501 \pm 31$ & & $5580-5380$ & \\
\hline & & KAM09-220/13 & KIA40369 & $6507 \pm 31$ & & $5570-5380$ & \\
\hline & & KAM09-223/8 & KIA40370 & $6480 \pm 36$ & & $5570-5380$ & \\
\hline & & SU_111/57 & KIA40368 & & & $5600-5460$ & \\
\hline & & SU_111/43 & KIA51511 & & & $5480-5360$ & \\
\hline & & SU_137 & Gif-12883 & & & $5600-5460$ & \\
\hline & & SU_220/13 & KIA40369 & & & $5580-5360$ & \\
\hline & & SU_223/8 & KIA40370 & & & $5520-5360$ & \\
\hline & & SU_307/31 & KIA40371 & & & $5540-5380$ & \multirow{13}{*}{ Helwing and Aliyev 2017: 41, table 2} \\
\hline & & SU_605/03 & KIA51512 & & & $5460-5320$ & \\
\hline & & SU_606/5 & KIA51508 & & & $5480-5340$ & \\
\hline & & SU_615 & Gif-12884 & & & $5480-5340$ & \\
\hline & & SU_626 & Gif-12885 & & & $5500-5340$ & \\
\hline & & SU_1005 & Gif-12889 & & & $5500-5340$ & \\
\hline & & SU_1006 & Gif-12890 & & & $5460-5340$ & \\
\hline & & SU_1008 & Gif-12891 & & & $5480-5220$ & \\
\hline & & SU_519/3 & KIA51510 & & & $5620-5500$ & \\
\hline & & SU__905 & Gif-12887 & & & $5620-5500$ & \\
\hline & & SU704/28 & KIA44738 & & & $5620-5480$ & \\
\hline & & SU704/28 & KIA51509 & & & $5620-5500$ & \\
\hline & & SU_715 & Gif-12886 & & & $5600-5460$ & \\
\hline
\end{tabular}




\begin{tabular}{|c|c|c|c|c|c|c|}
\hline Site & Level & Context & $n^{\circ}$ Lab & Date BP & Cal. BC (2 s) & Bibliographical references \\
\hline \multirow{4}{*}{ Kamiltepe } & & SU_1700 & Gif-12893 & & $5460-5320$ & \multirow{4}{*}{ Helwing and Aliyev 2017: 41, table 2} \\
\hline & & SU_1818/2 & MAMS-27328 & & $5480-5360$ & \\
\hline & & SU_1849/9 & MAMS-27327 & & $5620-5480$ & \\
\hline & & SU_1801-22 & Gif-13054 & & $5560-5320$ & \\
\hline \multirow{3}{*}{$\begin{array}{l}\text { Khramis Didi } \\
\quad \text { Gora }\end{array}$} & $\begin{array}{c}\text { IV (lower } \\
\text { level) }\end{array}$ & & TB-301 & $6437 \pm 50$ & $\begin{array}{l}5485-5420 \\
5510-5310^{*}\end{array}$ & $\begin{array}{l}\text { Menabde et al. 1980: } 34 \\
\text { Bohener and Schylde } 2006^{*}\end{array}$ \\
\hline & v & Close to Building 6 & LJ-3270 & $6540 \pm 70$ & $\begin{array}{l}5580-5290 \\
5640-5360^{*}\end{array}$ & $\begin{array}{c}\text { Linick 1977: } 30 \\
\text { Bohener and Schylde } 2006^{*}\end{array}$ \\
\hline & $\begin{array}{l}\text { VI (upper } \\
\text { level) }\end{array}$ & & TB-322 & $6505 \pm 60$ & $\begin{array}{l}5545-5265 \\
5600-5320^{*}\end{array}$ & $\begin{array}{l}\text { Kiguradze 1986: } 112 \text {, table 5; } \\
\text { Bohener and Schylde } 2006^{*}\end{array}$ \\
\hline \multirow{3}{*}{ Kültepe } & & $18.2 \mathrm{~m}$ deep & LE-477 & $5770 \pm 90$ & $\begin{array}{l}4745-4435 \\
4820-4420^{*}\end{array}$ & $\begin{array}{c}\text { lessen 1965: } 12 \\
\text { Bohener and Schylde } 2006^{*}\end{array}$ \\
\hline & & $15.35 \mathrm{~m}$ deep & LE-434 & $4870 \pm 150$ & $\begin{array}{l}3870-3505 \\
4040-3280^{*}\end{array}$ & $\begin{array}{l}\text { Dolukhanov and Timofeev 1972: 42; } \\
\text { Bohener and Schylde 2006* }\end{array}$ \\
\hline & $\begin{array}{c}\text { Late } \\
\text { Bronze } \\
\text { Age level }\end{array}$ & $8.5 \mathrm{~m}$ deep & LE-163 & $4880 \pm 90$ & $\begin{array}{l}3860-3540 \\
3890-3450^{*}\end{array}$ & $\begin{array}{l}\text { Butomo 1965: } 226 ; \\
\text { Bohener and Schylde } 2006^{*}\end{array}$ \\
\hline \multirow{4}{*}{ Masis Blur } & $\begin{array}{l}\text { II (lower } \\
\text { level) }\end{array}$ & MB-2 2012.M9/1.212.2110 & UCIAMS-121529 & $6995 \pm 20$ & $5925-5835$ & \multirow{4}{*}{$\begin{array}{l}\text { Martirosyan-Olshansky } \\
\text { et al. 2013: } 145, \text { table } 1\end{array}$} \\
\hline & \multirow{3}{*}{$\begin{array}{l}\text { I (upper } \\
\text { level) }\end{array}$} & MB-3 2012.M10/1.319.3085 & UCIAMS-121530 & $6940 \pm 25$ & $5885-5745$ & \\
\hline & & MB-1 2012.L10/4.105.1034 & UCIAMS-121528 & $6935 \pm 25$ & $5880-5740$ & \\
\hline & & MB-4 2012.M11/1.023.0259 & UCIAMS-121531 & $6765 \pm 25$ & $5715-5630$ & \\
\hline \multirow{21}{*}{$\begin{array}{l}\text { Mentesh } \\
\text { Tepe }\end{array}$} & \multirow{21}{*}{ I } & MT 2012, ANT 02 (Str. 342) & SacA 41508/Gif-13016 & $7010 \pm 45$ & 5993-5784 & Lyonnet et al. 2017: 128, table 1 \\
\hline & & MT 2011, ANT 12 (Str. 344, Burial 343) & SacA30643/Gif12232 & $6950 \pm 40$ & $5971-5736$ & Lyonnet et al. 2016: 180, table 2 \\
\hline & & MT 2014, ANT 04 (Str. 342) & Poz-68641 & $6930 \pm 40$ & $5899-5726$ & Lyonnet et al. 2017: 128, table 1 \\
\hline & & MT 2013, FLOT 302 (Su 588) & SacA37073/Gif-13045 & $6890 \pm 40$ & $5882-5707$ & \multirow{4}{*}{ Lyonnet et al. 2016: 180, table 2} \\
\hline & & MT 2012, FLOT 226 (Str. 536, Su 429) & SacA 31996/Gif-12992 & $6890 \pm 40$ & 5882-5707 & \\
\hline & & MT 2011, CHARB 35 (Loc. 231) & SacA 26232/Gif-12713 & $6875 \pm 35$ & $5842-5676$ & \\
\hline & & MT 2012, FLOT 270 (Str. 336, Su 430) & SacA 31997/Gif-12993 & $6865 \pm 35$ & $5837-5671$ & \\
\hline & & MT 2014, CHARB 25 (Su 685) & SacA 41340/Gif-13129 & $6835 \pm 35$ & $5784-5645$ & Lyonnet et al. 2017: 128, table 1 \\
\hline & & MT 2012, FLOT 269 (Str. 336, Su 451) & SacA 31998/Gif-12994 & $6825 \pm 40$ & 5783-5637 & Lyonnet et al. 2016: 180, table 2 \\
\hline & & MT 2014, FLOT $513($ Str. 798$)$ & SacA 41419/Gif-13139 & $6830 \pm 35$ & $5777-5642$ & Lyonnet et al. 2017: 128, table 1 \\
\hline & & MT 2012, ANT 8/CAZ 105 (Burial 578) & Poz-63145 & $6820 \pm 40$ & $5771-5636$ & Lyonnet et al. 2016: 180, table 2 \\
\hline & & MT 2014, FLOT 469 (Posthole 678) & SacA 41417/Gif-13137 & $6815 \pm 40$ & $5763-6533$ & Lyonnet et al. 2017: 128, table 1 \\
\hline & & MT 2012, ANT (Str. 342) & Beta-345514 & $6800 \pm 40$ & $5741-5631$ & \multirow{3}{*}{ Lyonnet et al. 2016: 180, table 2} \\
\hline & & MT 2013, CHARB 1 (Posthole 577) & SacA $37076 /$ Gif-13048 & $6805 \pm 35$ & $5738-5638$ & \\
\hline & & MT 2012, FLOT 281 (Str. 344, Su 548) & SacA 32000/Gif-12996 & $6805 \pm 35$ & $5738-5638$ & \\
\hline & & MT 2014, ANT 05 (Str. 342) & Poz- 68640 & $6790 \pm 40$ & $5734-5630$ & Lyonnet et al. 2017: 128, table 1 \\
\hline & & MT/KUR 2013, 09 & SacA 37081/Gif-13053 & $6795 \pm 35$ & $5732-5636$ & \multirow{5}{*}{ Lyonnet et al. 2016: 180, table 2} \\
\hline & & MT 2011, CHARB 112 (Loc. 342) & SacA 26234/Gif-12715 & $6780 \pm 35$ & $5726-5631$ & \\
\hline & & MT 2013, FLOT 303 (Su 582) & SacA 37072/Gif-13044 & $6745 \pm 45$ & 5726-5567 & \\
\hline & & MT 2013, CHARB 16 (Str. 536) & SacA 37079/Gif-13051 & $6775 \pm 35$ & $5724-5630$ & \\
\hline & & MT 2012, CHARB 25 (Str. 568) & SacA 32003/Gif-12999 & $6680 \pm 35$ & $5660-5537$ & \\
\hline Shomu Tepe & & $1 \mathrm{~m}$ deep & LE-631 & $7510 \pm 70$ & $6520-6200^{*}$ & $\begin{array}{l}\text { Kiguradze 1986: } 112 \text {, table 5; } \\
\text { Bohener and Schylde } 2006^{*}\end{array}$ \\
\hline \multirow{6}{*}{$\begin{array}{l}\text { Shulaveris } \\
\text { Gora }\end{array}$} & \multirow{3}{*}{$\begin{array}{l}\text { IX } \\
\text { (lower } \\
\text { level) }\end{array}$} & \multirow{3}{*}{$2.4 \mathrm{~m}$ deep } & SOAN-1292 & $6050 \pm 100$ & $\begin{array}{l}5210-4895 \\
5260-4700^{*}\end{array}$ & $\begin{array}{l}\text { Chubinishvili and Chelidze 1978: 66; } \\
\text { Bohener and Schylde 2006* }\end{array}$ \\
\hline & & & TB-16 & $6625 \pm 210$ & $\begin{array}{c}5715-5280 \\
5930-5170^{*}\end{array}$ & $\begin{array}{c}\text { Dzhavakhishvili and Dzhaparidze 1975: } \\
\text { 127; Bohener and Schylde 2006* }\end{array}$ \\
\hline & & & TB-72 & $6655 \pm 55$ & $\begin{array}{l}5680-5350 \\
5680-5480^{*}\end{array}$ & $\begin{array}{l}\text { Kiguradze 1986: } 112, \text { table 5; } \\
\text { Bohener and Schylde } 2006^{*}\end{array}$ \\
\hline & VII-VI & $1.6 \mathrm{~m}$ deep & LE-1099 & $6700 \pm 80$ & $\begin{array}{l}5745-5365 \\
5760-5480^{*}\end{array}$ & $\begin{array}{l}\text { Dzhavakhishvili and Dzhaparidze 1975: } \\
\text { 127; Bohener and Schylde } 2006^{*}\end{array}$ \\
\hline & \multirow{2}{*}{$\begin{array}{l}\text { II } \\
\text { (upper } \\
\text { level) }\end{array}$} & $0.2 \mathrm{~m}$ deep & TB-15 & $5920 \pm 300$ & $\begin{array}{l}5285-4440 \\
5510-4150^{*}\end{array}$ & \multirow{2}{*}{$\begin{array}{l}\text { Kiguradze 1976: } 168 \\
\text { Bohener and Schylde } 2006^{\star}\end{array}$} \\
\hline & & $0.1 \mathrm{~m}$ deep & LE-1100 & $6310 \pm 130$ & $\begin{array}{l}5375-5070 \\
5580-4940^{*}\end{array}$ & \\
\hline
\end{tabular}

\section{ARCHITECTURAL MATERIALS AND METHODS}

In order to study architecture, it is necessary to establish an adequate methodology. The first step is to set up a typology, taking into account the building materials, layout techniques and morphology of the buildings (fig. 2). After processing all the data at hand, it has been possible to underline different distributions of the building techniques used according to geographical, cultural and chronological parameters, ultimately leading to observed technical exchanges between the cultures previously described. 


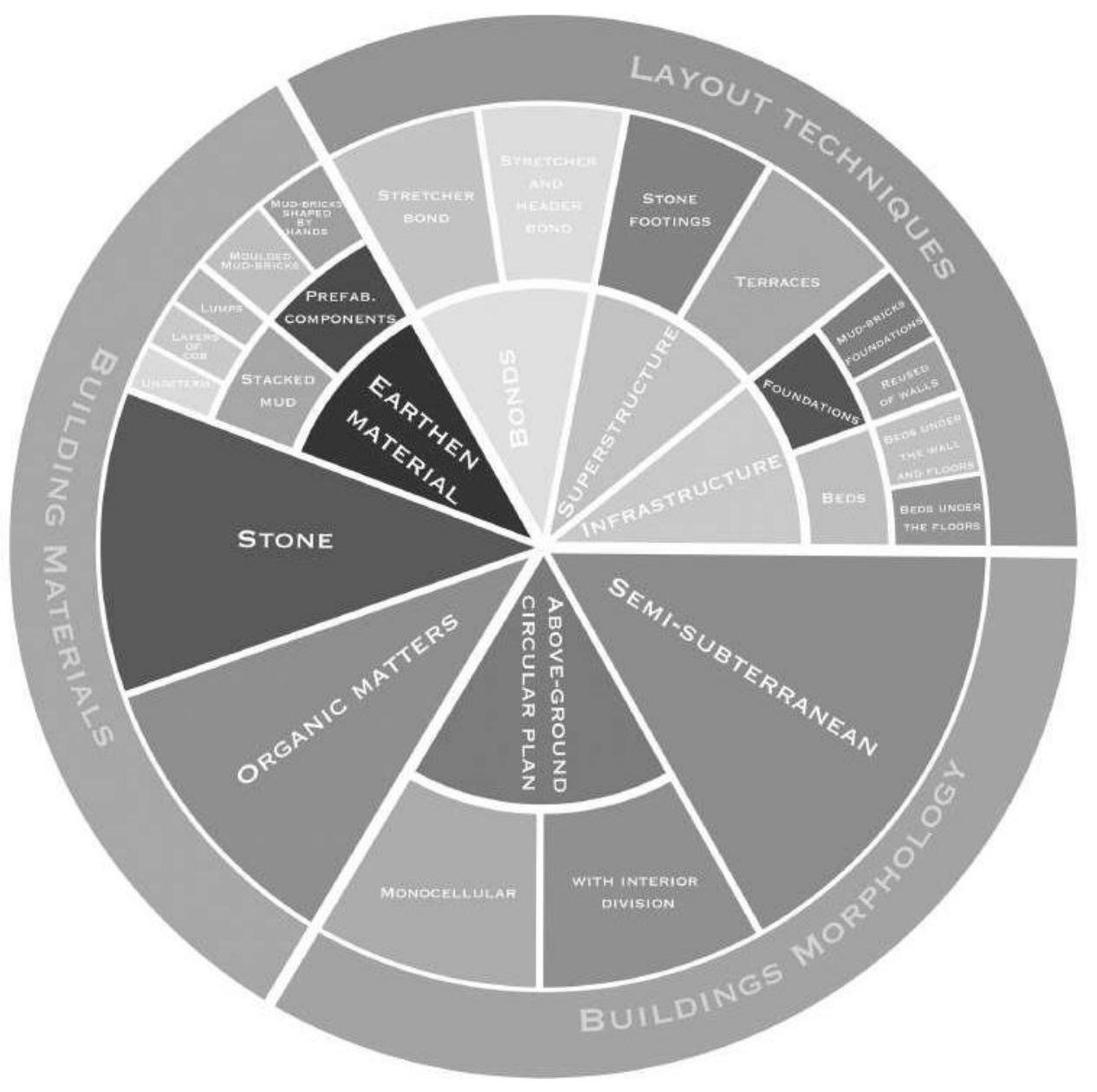

Fig. 2 - Summary diagram of general typology (E. Baudouin).

We consider the architecture as an archaeological object in its own right, with technical characteristics that can be decomposed as with other artefacts. Moreover, unlike the objects of material culture, architecture represents a specific vehicle for transmitting technical and cultural knowledge because it does not circulate as a finished artefact but rather as an idea, a technique and know-how. This approach is inspired by $\mathrm{O}$. Aurenche's research: his typology of the architectural techniques in the Near East serves as a base for this study (Aurenche 1981). Analysis of the publications and excavation archives has to be considered as a second-hand dataset because it cannot be verified directly in the field; therefore, due to the absence of drawings or photos, we have used the authors' descriptions in order to build our own typology (Baudouin et al. 2018: 60, fig. 12).

Altogether, 23 sites are included in this corpus and nearly 400 buildings have been studied. However, a major bias has to be underlined, i.e., the frequent absence of precise stratigraphic context. The lack of some crucial information, either because it was not possible to examine the archives or because the data is absent (e.g., sections, plans, photographs), prevents a full re-evaluation of the documentation and does not allow the proposing of a sound reassessment of the stratigraphy.

Finally, my participation in the excavations at Mentesh Tepe $^{9}$, Gadachrili Gora $^{10}$ and Kiçik Tepe ${ }^{11}$ allowed me to collect new data on SSC architectural techniques. To this field-

9. Directed by B. Lyonnet (Centre national de la recherche scientifique [CNRS]) andF.Guliyev (Institute of Archaeology andEthnography, National Academy of Sciences, Azerbaijan) and financed by several institutions: ministère français des Affaires étrangères et du développement international (MAEDI), laboratoires internationaux associés (LIA du CNRS, AzArLi, AzAr2), Agence nationale de recherche (ANR) Ancient Kura, ANR Kura in Motion!.

10. Directed by M. Jalabadze (Georgian National Museum) since 2006, and C. Hamon (CNRS) in 2012-2013. Financed by the Georgian Wine Agency, LIA GATES, ANR Kura in Motion! and ANR Orimil. The site is actually being excavated by the Gadachrili Gora Regional Archaeological Project Excavation (GRAPE) directed by S. Batiuk (University of Toronto) and M. Jalabadze (Batiuk et al. 2017).

11. Directed by G. Palumbi (CNRS) and F. Guliyev, and financed by MAEDI. 
work data is also added that from Göy Tepe and Haci Elamxanl1 Tepe, which I was able to consult in the archives of the Azebaijan-Japan archaeological expedition at the University of Tokyo. ${ }^{12}$

\section{RESULTS}

\section{BUILDING MATERIALS}

The building materials used for construction fall into three main categories: earthen, stone and organic matter (fig. 2).

\section{Earthen material}

Over the last three decades, specialised studies have clarified our knowledge of mud-bricks (Aurenche et al. 2011; Chazelles and Klein 2003; Sauvage 1998), pisé (Chazelles and Klein 2003) and cob techniques (Roux and Cammas 2010). These studies have allowed a revision of the terminologies, as well as a more accurate definition of these building materials. Based on the evolutionary model of the Near Eastern PPN communities, it has been possible to identify and distinguish autonomous inventions (first occurrences of both cob and mud-bricks, for example) from processes of technical diffusion between different regions or cultures (Sauvage 2009: 193-194). Stacked mud (Roux and Cammas 2010) and prefabricated components (Sauvage 1998; 2001) need two different chaînes opératoires due to the use of different types of earthen material.

\section{Stacked mud}

The notion terre massive (stacked mud) indicates a building technique where mud is put directly on the spot where the wall will be built (Chazelles-Gazzal 1997: 85). It includes two main techniques: cob and pisé. Although their development and degree of technicality are distinct, their differences have only recently been noticed thanks to new research (ChazellesGazzal 1997). It is now becoming customary to strictly limit the use of the word pisé when the mud, used in a plastic state, is packed between shutters with a hammer (Aurenche et al. 2011: 16, fig. 2, 22). Cob is shaped directly on the spot to dry, so as to reach the necessary consistency before the elevation of

12. I express my deepest thanks to the excavation directors at both sites, F. Guliyev and Y. Nishiaki, who gave me this opportunity. This research was carried out as part of a post-doctorate programme at The University Museum, The University of Tokyo, under the direction of Y. Nishiaki and with the financial support of the Japan Society for the Promotion of Science (JSPS).
Table 2 - Earthen material - cob (E. Baudouin).

L: lumps; LC: layers of cob; und.: undetermined.

\begin{tabular}{|c|c|c|c|c|}
\hline Site & Culture/level & Building & Implementation & $\begin{array}{l}\text { Bibliographical } \\
\text { references }\end{array}$ \\
\hline \multirow{2}{*}{ Aruchlo } & SSC & 9 & \multirow{2}{*}{ und. } & \multirow{2}{*}{ Chataigner 1995: 59} \\
\hline & $\mathrm{SSC} / \mathrm{I}$ & 4 & & \\
\hline $\begin{array}{l}\text { Gadahrili } \\
\text { Gora }\end{array}$ & SSC/II & Wall 217 & $L$ & $\begin{array}{l}\text { Hamon et al. 2016: } \\
\text { 164-165, fig. } 23\end{array}$ \\
\hline Kültepe & Kültepe & General & und. & $\begin{array}{c}\text { Abibullaev 1963: } \\
157-158\end{array}$ \\
\hline \multirow[t]{2}{*}{ Masis Blur } & \multirow[t]{2}{*}{ SSC/I } & $\begin{array}{c}\text { S003, } \\
\text { S004, S005 }\end{array}$ & $L$ & \multirow{2}{*}{$\begin{array}{c}\text { Hayrapetyan et al. } \\
\text { 2014: } 180\end{array}$} \\
\hline & & S011 & LC & \\
\hline $\begin{array}{c}\text { Shulaveris } \\
\text { Gora }\end{array}$ & SSC & General & und. & $\begin{array}{c}\text { Chataigner 1995: } \\
\text { 59; Dzhavakhishvili } \\
\text { and Dzhaparidze } \\
\text { 1975: 203; Sagona } \\
\text { 1993: } 456\end{array}$ \\
\hline
\end{tabular}

the next bed. The mud is usually composed of earth, removed from near the site of the building, mixed with water and occasionally with an organic temper.

The establishment of a new typology (Roux and Cammas 2010: 222-223) also enables us to identify two layout techniques mainly used in the Southern Caucasus: lumps and layers of cob.

Several recent discoveries in the Kvemo-Kartli (Gadachrili Gora) and in the Ararat Plain (Masis Blur) argue for the use of lumps of mud and/or clay layers (fig. 3a and table 2). At other sites, as at Aruchlo, Shulaveris Gora and Kültepe, the use of the cob technique is documented but it is not possible to determine which specific layout was used. At Aruchlo and Shulaveris Gora, stacked mud and plano-convex mud-bricks were used simultaneously (see below).

\section{Prefabricated components (mud-bricks)}

Prefabricated components are made in series and prepared in advance. We distinguish between sun-dried mud-bricks shaped by hand and sun-dried moulded mud-bricks made in a wooden frame. The latter technique can afford the standardisation of both the shape and size of the mud-bricks at a high production rate (Aurenche 1981: 66). The composition of mud-bricks is almost always similar: it is a mixture of earth, water and often an organic temper, occasionally mineral (Aurenche 1977: 40).

In the Southern Caucasus, two morphological types of sun-dried mud-bricks have been identified: plano-convex mud-bricks, flat on one side and curved on the other, more characteristic of the SSC in the Kura Valley (table 3; fig. 4a), and elongated and flat mud-bricks, better known in the AC in the Araxes Valley, though they are also present at some sites in 


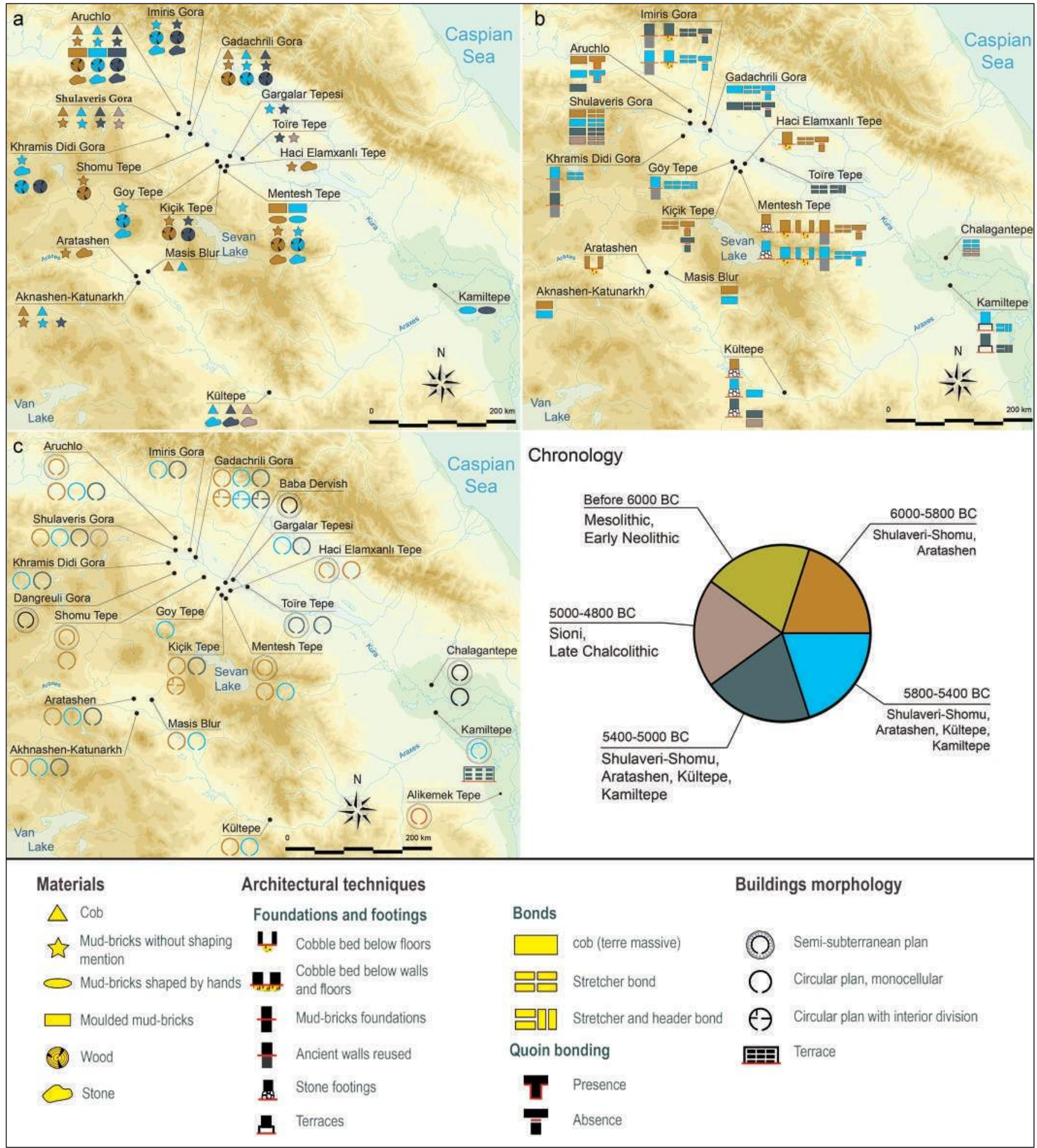

Fig. 3 - Synthetic maps. a. Building materials; b. Layout techniques; c. Buildings morphology (E. Baudouin). 
Table 3 -Earthen material-mud-bricks (E. Baudouin). F: flat; $\boldsymbol{M}$ : moulded; $\boldsymbol{m}$ : shaped by hands; Pl-cx: plano-convex.

\begin{tabular}{|c|c|c|c|c|c|c|c|c|}
\hline Site & Culture/level & Building & Length (in $\mathrm{cm}$ ) & Width (in cm) & Height (in cm) & Ratio (L/w) & $\begin{array}{c}\text { Technique } \\
\text { and/or shape }\end{array}$ & Bibliographical references \\
\hline \multirow{3}{*}{$\begin{array}{l}\text { Aknashen- } \\
\text { Katunarkh }\end{array}$} & \multirow{2}{*}{$\mathrm{AC} / \mathrm{VII}$} & & 50 & 25 & & 2 & \multirow{3}{*}{$\mathrm{F}$} & \multirow{3}{*}{$\begin{array}{l}\text { Badalyan and Harutyunyan 2014: } \\
\qquad 165\end{array}$} \\
\hline & & & $19-20$ & 14 & 5 & 1.4 & & \\
\hline & $\mathrm{AC} / \mathrm{IV}$ & & 50 & 30 & 20 & 1.7 & & \\
\hline Aratashen & $\mathrm{AC} / \mathrm{l}$ & & 45 & 25 & 8 & 1.8 & $\mathrm{~F}$ & Badalyan et al. 2004: 402 \\
\hline \multirow{6}{*}{ Aruchlo } & $\begin{array}{l}\text { SSC/Older Neo- } \\
\text { lithic settlement }\end{array}$ & Complex III & $30-50$ & 20 & 5 & $1.5-2.5$ & PI-cx & Hansen and Ullrich 2017: 202 \\
\hline & \multirow{5}{*}{ SSC } & C030? & 41 & 20 & 8 & 2.1 & & \multirow{4}{*}{ Dzhavakhishvili 1973: 80} \\
\hline & & \multirow{4}{*}{ General } & 40 & $13-15$ & 8 & $2.7-3.1$ & & \\
\hline & & & $27-32$ & $17-18$ & 10 & $1.6-1.8$ & & \\
\hline & & & $18-19$ & $9-17$ & $7.5-9$ & $1.1-2$ & & \\
\hline & & & $31-37$ & $14-19$ & $9-12$ & $1.6-2.6$ & $\mathrm{M}$ & Ioseliani 2017a: 281. table 1. \\
\hline \multirow{6}{*}{$\begin{array}{l}\text { Gadachrili } \\
\text { Gora }\end{array}$} & \multirow{3}{*}{ SSC/I } & 2002 & $20-26$ & $12-14$ & 8 & $1.4-1.7$ & Pl-cx & $\begin{array}{c}\text { Hamon et al. 2016: 160, 162-163; } \\
\text { personal data }\end{array}$ \\
\hline & & \multirow{2}{*}{2003} & 19 & 19 & 5 & 1 & $\mathrm{~F}$ & \multirow{2}{*}{$\begin{array}{l}\text { Hamon et al. 2016: 160-161; } \\
\text { personal data }\end{array}$} \\
\hline & & & 40 & 19 & 9 & 2.1 & $\mathrm{PI}-\mathrm{cx}$ & \\
\hline & \multirow[t]{2}{*}{ SSC/I } & 2004 & 50 & 25 & & 2 & $\mathrm{~F}$ & $\begin{array}{l}\text { Hamon et al. 2016: 159; } \\
\text { personal data }\end{array}$ \\
\hline & & & $38-40$ & $15-20$ & $8-10$ & $2.5-2.7$ & & \multirow{2}{*}{ Personal data } \\
\hline & SSC & Wall 234 & 23 & & 7 & & & \\
\hline \multirow{5}{*}{$\begin{array}{l}\text { Gargalar } \\
\text { Tepesi }\end{array}$} & \multirow{3}{*}{$\mathrm{SSC} / 3$} & 4 & 36 & 16 & 8 & 2.3 & & \multirow{4}{*}{ Narimanov 1992: 21} \\
\hline & & 9 & $26-40$ & 15 & $7-8$ & $1.7-2.7$ & & \\
\hline & & +2 & 50 & 20 & $8-10$ & 2.5 & & \\
\hline & $\mathrm{SSC} / 2$ & General & $34-44$ & $14-18$ & $7-11$ & $2.4-2.8$ & & \\
\hline & $\mathrm{SSC} / 1$ & & $40-48$ & $16-18$ & $7-9$ & $2.5-3$ & & Narimanov 1992: 20. \\
\hline Gäx Tono & $\operatorname{ccc}(14$ to 1 & 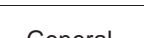 & $30-50$ & $15-18$ & 10 & $1.7-3.3$ & DI 0 ond 5 & Culiu ond Nlichiole on14. \\
\hline Göy Tepe & $\mathrm{SSC} / 14$ to 1 & General & $40-60$ & 20 & $8-10$ & $2-3$ & PI-cx and F & Guliyev and Nishiaki 2014: 5 \\
\hline & SSC/IV & 35 & $38-41$ & 16 & $10-11$ & $2.4-2.6$ & & $\begin{array}{l}\text { Dzhaparidze and Dzhavakhishvili } \\
1971: 28\end{array}$ \\
\hline Imiris Gora & & & $38-50$ & $15-20$ & 10 & $2.5-2.6$ & $\mathrm{Pl}-\mathrm{cx}$ & \\
\hline & SSC & General & $32-35$ & $16-20$ & $7-11$ & $1.6-2.2$ & & Dzhavakhishvili 1973: 48 \\
\hline Kamiltepe & Kamiltepe/Phase & & $16-20$ & $15-19$ & & 1.1 & $\mathrm{~m}$ & $\begin{array}{l}\text { Aliyev and Helwing 2009:29; } \\
\text { Helwing and Aliyev 2017:17 }\end{array}$ \\
\hline & & & 34 & 18 & 15 & 1.9 & & Narimanov 1992: 35 \\
\hline & SSC/III & 27 & 42 & 20 & 7-7.5 & 2.1 & Pl-cx? & \\
\hline Khramis & $\csc / 1$ & 34 & $42-49$ & $16-24$ & 7 & $2-2.7$ & Plone & Kiruradze 1086. 70 \\
\hline Didi-Gora & SSC/I & 29 & $42-43$ & $20-22$ & 7.5 & $1.9-2.2$ & Pl-cx? & Kiguradze 1986: 70 \\
\hline & SSC & General & $36-48$ & $18-24$ & 7-7.5 & $2-2.3$ & PI-cx & \\
\hline & & STR-2 & $48-53$ & 23 & $8-9$ & $2.1-2.3$ & & \\
\hline & $\csc / \mu$ & STR-26 & 49 & 14 & 9 & 3.5 & & \\
\hline Kiçik Tepe & SSC/III & CTR 21 & $20-25$ & 19 & 9 & $1.1-1.3$ & $\mathrm{~m} ? ; \mathrm{F}$ & Personal data \\
\hline & & $S T R-21$ & $42-44$ & 19 & 9 & $2.2-2.3$ & & \\
\hline & SSC/II & STR-18 & 50 & 20 & 9 & 2.5 & & \\
\hline & & $285=689$ & $44-45$ & $15-16$ & $9-10$ & $2.8-3$ & & \\
\hline & & 293 & 43 & 15 & 10 & 2.9 & M; PI-cx & \\
\hline & & 284 & 43 & 14 & 9 & 3.1 & & \\
\hline Mentesh & & 516 & 43 & 14 & 9 & 3.1 & & \\
\hline Tepe & $\mathrm{SSC} / \mathrm{l}$ & $718=337$ & 40 & 15 & 10 & 2.7 & $\mathrm{~m}$ or M?; Pl-cx & Personal data \\
\hline & & 1025 & 43 & 12 & 10 & 3.6 & & \\
\hline & & 1031 & 39 & 13 & 10 & 3 & & \\
\hline & & 346 & 28 & 22 & 8 & 1.3 & $\mathrm{~m}$ & \\
\hline Shomu & & & $50-55$ & $22-25$ & 8 & $2-2.5$ & & Chataigner 1995: 72 \\
\hline Tepe & SSC & General & $32-36$ & $13.5-16$ & $8-9$ & $2.1-2.7$ & Pl-cx & Narimanov 1987: 86 \\
\hline Shulaveris & & & $35-50$ & $15-25$ & $7-10$ & $1.7-2.8$ & & \\
\hline Gora & SSC & General & $25-30$ & $15-20$ & $7-8$ & $1.4-1.7$ & Pl-cx & Dzhavakhishvili 1973: 19 \\
\hline & SSC/I & 15 & 37 & 17 & 8 & 2.2 & & Narimanov 1992: 14 \\
\hline & SSC/II & & 37 & 18 & 9 & 2.1 & & \\
\hline Toïre Tepe & SSC/III & 1 & 36 & 18 & 9 & 2 & & Narimanov 1992: 16 \\
\hline & $\mathrm{SSC} / \mathrm{V}$ & 22 & $50-55$ & $22-25$ & $7-8$ & $2-2.5$ & & Narimanov 1987: 86; Narimanov \\
\hline & SSC & General & $35-55$ & $14-25$ & $7-10$ & $2-2.7$ & & 1992: 18 \\
\hline
\end{tabular}



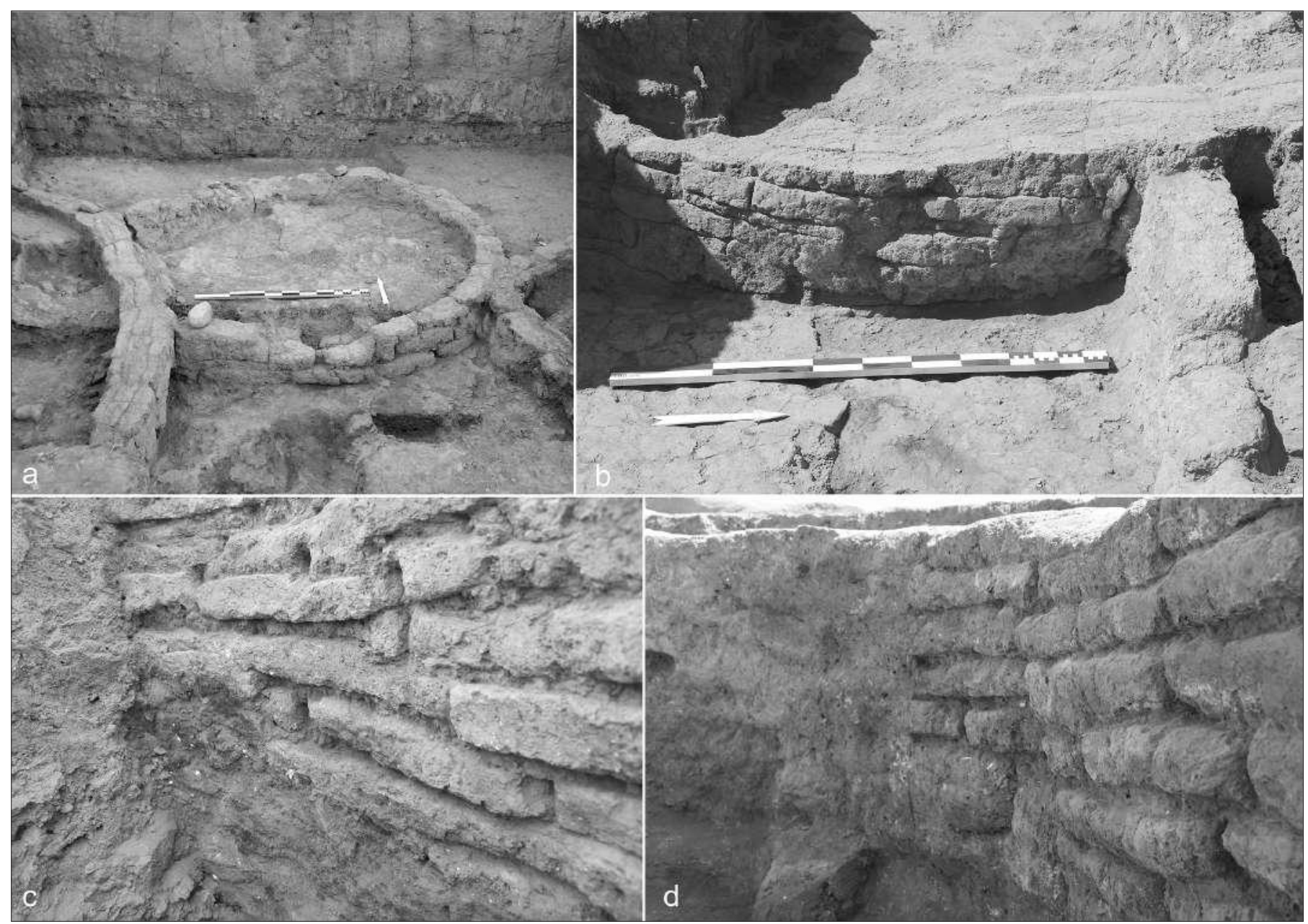

Fig. 4 - Examples of mud-brick walls. a. Gadachrili Gora, Building 2003, trench 2, with plano-convex mud-bricks, view from the south (C. Hamon); b. Gadachrili Gora, detail of the south part of Building 2004, trench 2, with flat and elongated mud-bricks, view from the east (C. Hamon); $\boldsymbol{c}$. Kiçik Tepe, detail of the burnt coating and flat and elongated mud-bricks of Building 21, view from the north-west (Mission Boyuk Kesik, MEAE); d. Kiçik Tepe, detail of the Building 2 with, on the left, the mud coating on the mud-brick wall and, on the right, the wall after removal of coating, view from the north-west (Mission Boyuk Kesik, MEAE).

the Kura Valley (Göy Tepe ${ }^{13}$ ) and the Kvemo-Kartli Plain

(fig. 4b-d). C. Chataigner (1995: 57) proposed to identify plano-convex bricks as mud-bricks shaped by hand, similar to the curved bricks produced during the PPNA in the Near East.

Mud-bricks can be classified into three dimensional categories (fig. 5): small (length less than $20 \mathrm{~cm}$ ), medium (length $c a .25-35 \mathrm{~cm}$ ) and large (length greater than $35 \mathrm{~cm}$ ). Until the middle of the $6^{\text {th }}$ millennium $\mathrm{BC}$ the size of mud-bricks is highly variable, longer than $40 \mathrm{~cm}$ long or shorter than $20 \mathrm{~cm}$.

13. Plano-convex mud-bricks only appear in the lower levels, being replaced by flat mud-bricks in subsequent levels (Y. Nishiaki, personal communication).
After this period, the size of mud-bricks tends to be standardised: small mud-bricks are no longer produced and the difference between the medium and large mud-bricks decreases, while the ratio $\mathrm{L}: \mathrm{W}$ tends to standardise between 2:1 and 3:1. At the scale of the same settlement, a decrease in size is observed at Gargalar Tepesi (Narimanov 1992: 20-21), Aruchlo (Hansen and Ullrich 2017: 209, fig. 33, 210, fig. 23) and Toïre Tepe (Narimanov 1987: 86; 1992: 14), while an increase in size is visible from levels 13 to 1 at Göy Tepe (Y. Nishiaki, personal communication).

Until now, no reliable information was available on the manufacturing technique of mud-bricks (fig. 3a; table 3). But 


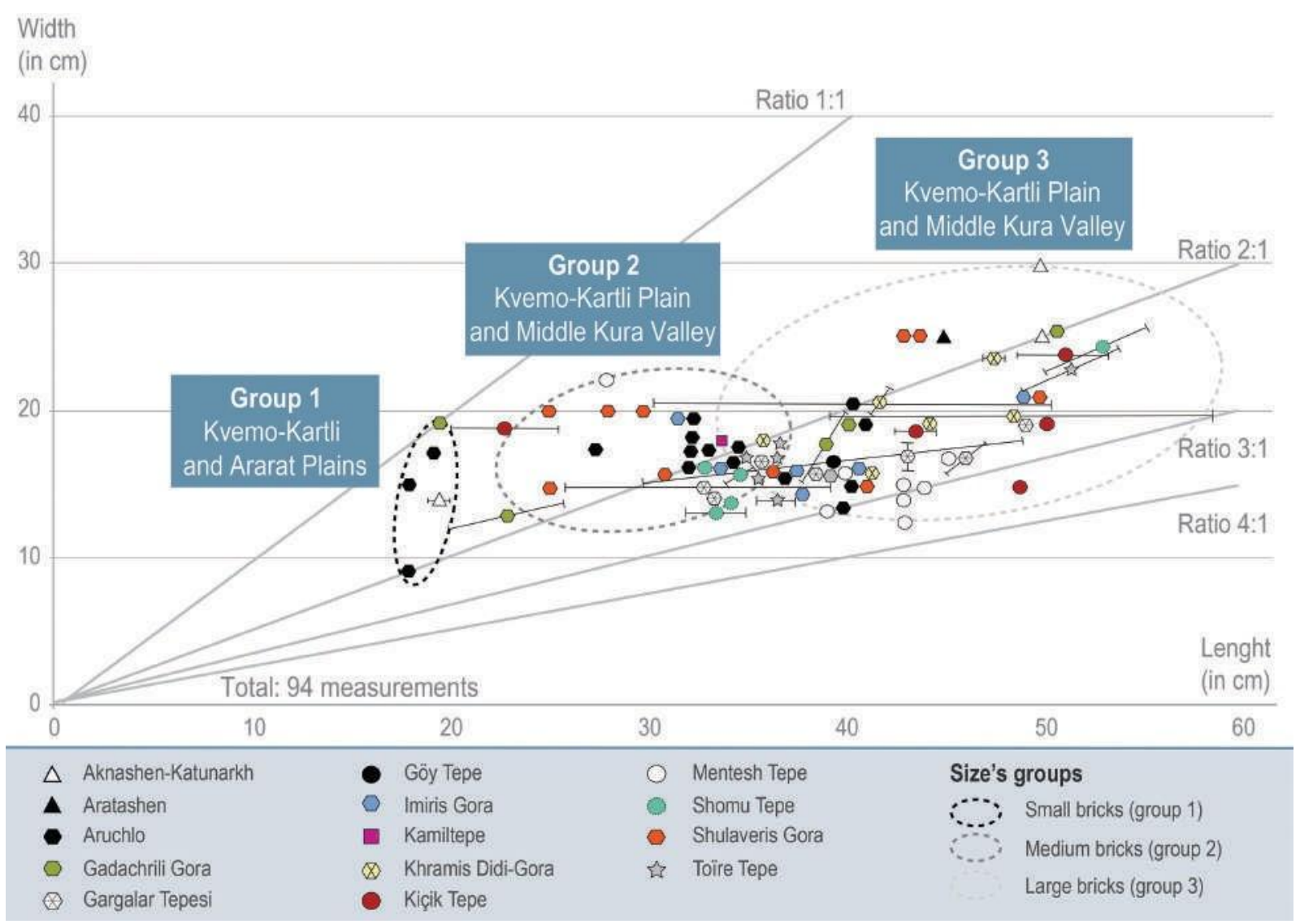

Fig. 5 - Summary diagram of the attestations of mud-bricks during the $6^{\text {th }}$ millennium BC (E. Baudouin).

recent research at Aruchlo (Ioseliani 2017a) and Mentesh Tepe (Baudouin et al. 2018) confirms the use of moulded planoconvex mud-bricks during the first third of the $6^{\text {th }}$ millennium BC in the SSC. At Mentesh Tepe (fig. 6), the moulded mud-bricks present edges which are perfectly straight with a tiny rim visible at the top due to the removal of the frame (Baudouin et al. 2017: 44-45, fig. 4). In addition, slight longitudinal ridges on the convex face of several mud-bricks possibly testify to an equalisation of the surface - probably with a toolbefore the removal of the frame (fig. 6b-c). ${ }^{14}$ At Aruchlo, the moulded plano-convex mud-bricks have been identified in a burnt collapsed level said to belong to the oldest occupation of the site. These mud-bricks have a standard size and specific stigmas (Ioseliani 2017a: 282) that are similar to those observed

14. They could also be simply fingerprints, attested, for example, on the top of Sumerian plano-convex mud-bricks in Mesopotamia during the Early Dynastic period (Sauvage 1998: 41-42). In this case, the manufacturing technique is ambiguous: moulded (Delougaz 1933: 8, fig. 4) or shaped by hand (Tunca 1984: 122-123), according to the authors (Sauvage 1998: 115-116). at Mentesh Tepe. These results will have to be confirmed by further research in the Southern Caucasus: the issue of a technical evolution from mud-bricks shaped by hand to moulded mud-bricks is essential to define a local evolution of techniques or, on the contrary, a diffusion of the moulded mud-brick technique, from Mesopotamia to the Southern Caucasus.

\section{Stone}

In addition to the earthen materials, and contrary to what is sometimes written (Kushnareva 1997: 31), stone was commonly used (table 4), but for specific needs (see below).

This is the case of the footings at Mentesh Tepe, with small river pebbles (Baudouin et al. 2018: 56, fig. 5), at Kültepewhere stone blocks were employed, and for the foundations at Mentesh Tepe (Baudouin et al. 2018: 56, fig. 5, 57, fig. 6), Haci Elamxanlı Tepe and Aratashen. Pebbles were also used to maintain posts at Aruchlo and Mentesh Tepe (Baudouin et al. 2017: 46, fig. 5). 


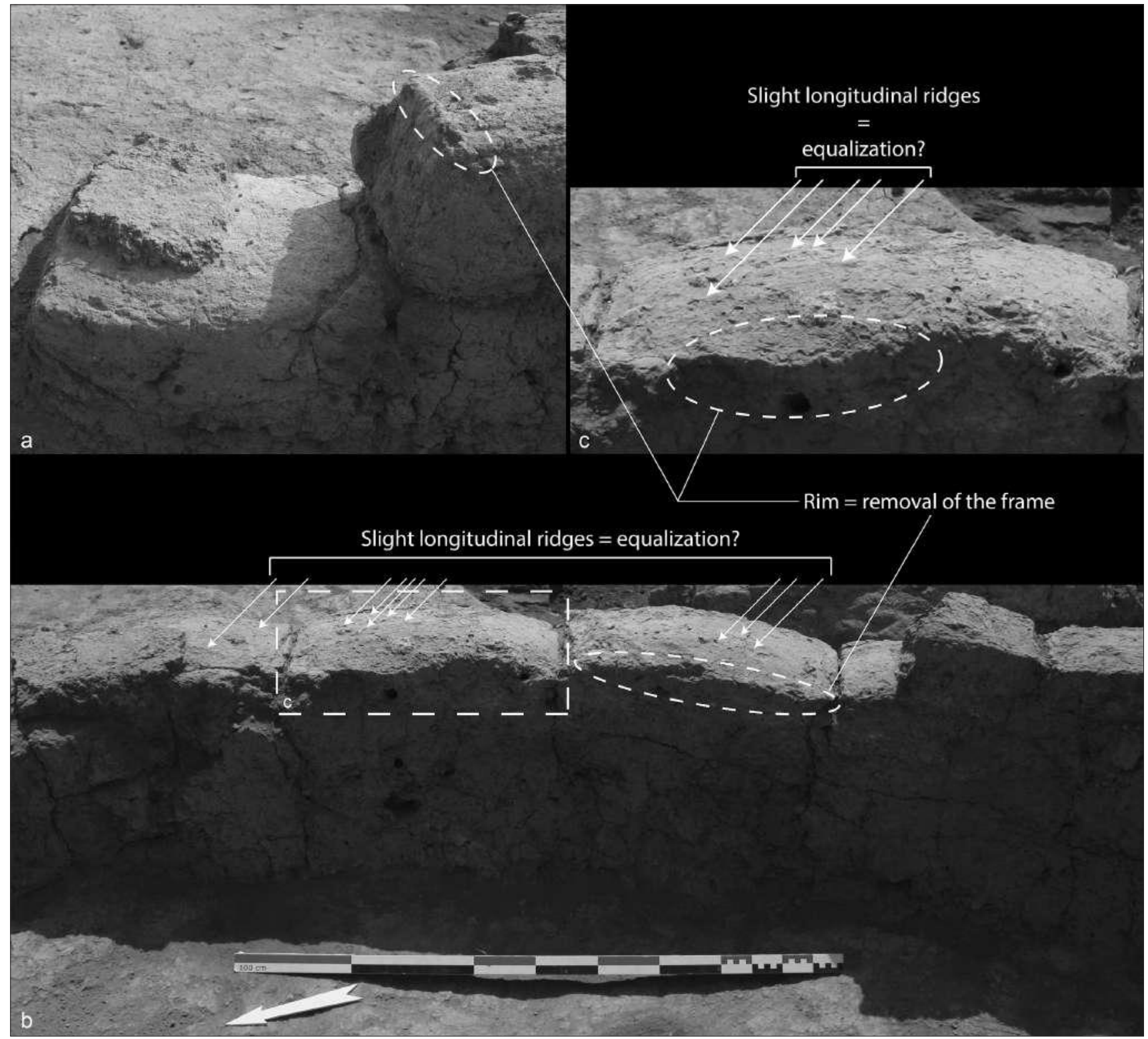

Fig. 6 - Moulded plano-convex mud-bricks from Mentesh Tepe (Mission Mentesh Tepe). a. Detail of the mud-bricks, Wall 293, sector 10, with stigmas of removal of the frame, view from the west; $\boldsymbol{b}$. First course of mud-brick, Wall 285, sector 15, with rims and slight longitudinal ridges at the top of mud-bricks, view from the north-west; $c$. Detail of a mud-brick, Wall 285, with equalisation marks on the top.

\section{Organic matter}

In addition to earth and stone, organic matter (table 5), essentially consisting of wood, straw and reeds, were used in different aspects of the construction..$^{15}$

15. In the current state of knowledge, the wattle technique is not attested in the Southern Caucasus during the Neolithic period. Organic matter seems to be used preferentially for roof coverings and supporting posts.
In the SSC, the best evidence of the use of organic matter is represented by postholes for the roof supports. At Aruchlo, recent discoveries emphasise the use of load-bearing poles in several buildings (Hansen and Ullrich 2017: 203, 207, fig. 15), with occasional imprints of wood on pieces of daub (Ioseliani 2017a: 282, 285, fig. 10). At Kiçik Tepe, wood and straw imprints were identified on earthen materials from the collapsed roof (fig. 7). The sizes of the beams are estimated to 


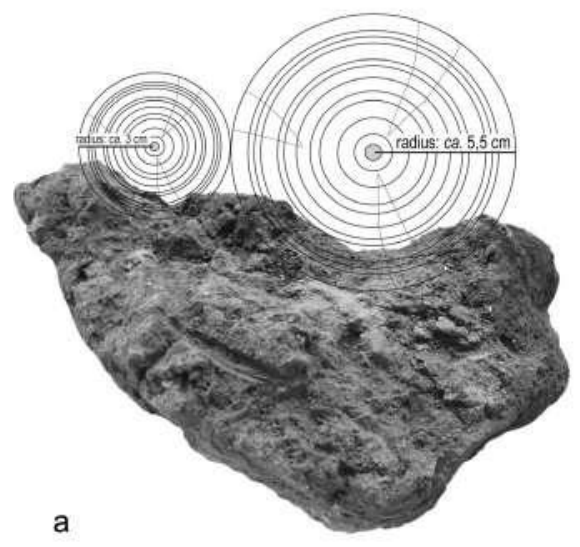

b

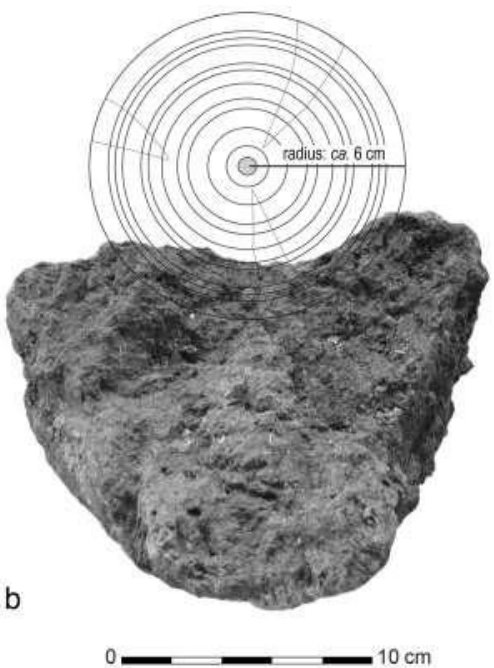

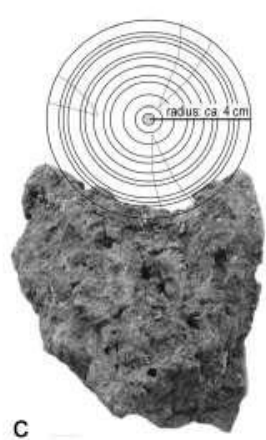

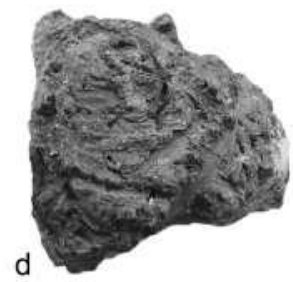

Fig. 7 - Kiçik Tepe, Building 21, square G8 (Mission Boyuk Kesik, MEAE). a-c. Earthen fragment with imprints of pole (E. Baudouin); d. Earthen fragment with imprints of straw and reed (E. Baudouin).

Table 4 -Material - stones (E. Baudouin).

\begin{tabular}{|c|c|c|c|}
\hline Site & Culture/level & Building & Bibliographical references \\
\hline Aratashen & $\mathrm{AC} / \mathrm{llc}, \mathrm{Ilb}$ & Str. 47; Str. X & Badalyan et al. 2007: 41 \\
\hline Aruchlo & SSC & Complex III & $\begin{array}{c}\text { Hansen and Ullrich 2017: } \\
203,206 \text {, fig. } 14,207 \text {, fig. } 15\end{array}$ \\
\hline $\begin{array}{c}\text { Haci } \\
\text { Elamxanlı } \\
\text { Tepe }\end{array}$ & $\mathrm{SSC} / 2$ & Wall 75 & Nishiaki et al. 2013: 7 \\
\hline Kültepe & Kültepe & General & $\begin{array}{l}\text { Chataigner 1995:60; } \\
\text { Abibullaev 1959: } 445\end{array}$ \\
\hline \multirow{4}{*}{$\begin{array}{l}\text { Mentesh } \\
\text { Tepe }\end{array}$} & \multirow{4}{*}{$\mathrm{SSC} / \mathrm{l}$} & 293 & Baudouin et al. 2017: 46, fig. 5 \\
\hline & & 782,783 & Baudouin et al. 2018: 56-57, fig. 4 \\
\hline & & 795 & Baudouin et al. 2018: 56-57, fig. 6 \\
\hline & & 718 & Baudouin et al. 2018: 56, fig. 5 \\
\hline
\end{tabular}

have been $c a .6-12 \mathrm{~cm}$; the excavation of the roof collapse layer also revealed a thick level of straw and charred wood remains. At Mentesh Tepe, the discovery of postholes on the periphery of a round building together with the imprint of one central pole enables us to restore a system of roof-supporting posts (see below). In a building at Gadachrili Gora, the presence of a small circular cavity near the entrance indicates the location of a door pivot (fig. 8d).

\section{LAYOUT TECHNIQUES}

Several layout techniques can be defined, according to the building materials used and their position below (infrastructures) or above (superstructures) the ground level.
Table 5 - Material - organic matters (E. Baudouin). I: imprints; $\boldsymbol{P}$ : pole; $\boldsymbol{P h}$ : posthole.

\begin{tabular}{|c|c|c|c|c|}
\hline Site & Culture/level & Building & Type & Bibliographical references \\
\hline \multirow[b]{2}{*}{ Aruchlo } & \multirow[b]{2}{*}{ SSC } & General & $\mathrm{Ph}$ & Hansen and Ullrich 2017: 203 \\
\hline & & $\begin{array}{l}\text { Carbonised } \\
\text { layer }\end{array}$ & I & Ioseliani 2017a: 282 \\
\hline $\begin{array}{l}\text { Gadachrili } \\
\text { Gora }\end{array}$ & SSC/I & 2003 & $\mathrm{Ph}$ & Personal data \\
\hline Göy Tepe & SSC & General & $\mathrm{Ph}$ & Guliyev and Nishiaki 2014: 5 \\
\hline Imiris Gora & SSC/I & $9-10$ & $\mathrm{Ph}$ & $\begin{array}{c}\text { Dzhavakhishvili and } \\
\text { Dzhaparidze 1975: fig. 1, pl. XV }\end{array}$ \\
\hline $\begin{array}{l}\text { Khramis } \\
\text { Didi Gora }\end{array}$ & SSC & 23 and 28 & $\mathrm{Ph}$ & Sagona 1993: 460 \\
\hline Kiçik Tepe & SSC/III & 21 & $P ; I$ & Personal data \\
\hline $\begin{array}{l}\text { Mentesh } \\
\text { Tepe }\end{array}$ & SSC/I & 293 & $\mathrm{Ph}$ & $\begin{array}{c}\text { Baudouin et al. } 2018: \\
61,64 \text {, fig. } 14\end{array}$ \\
\hline $\begin{array}{l}\text { Shomu } \\
\text { Tepe }\end{array}$ & SSC & & $\mathrm{Ph}$ & Narimanov 1992: 12 \\
\hline
\end{tabular}

\section{Infrastructures}

Two types of infrastructures have been identified: stone or clay beds and constructed foundations (fig. 2, fig. $3 \mathrm{~b}$ and table 6). Three specific functions are assigned to the stone or clay beds depending on whether they are installed inside the building or only under the walls: 1) to protect it from humidity; 2) to level and/or raise the building surface; 3) to prevent moisture infiltration (Baudouin et al. 2018: 58, fig. 8). According to the typology established by Gasche and Birchmeier (Gasche and Birchmeier 1981: 8-9), two types of constructed foundations can be recognised in the Southern Caucasus: the reuse of previous walls or the construction of 


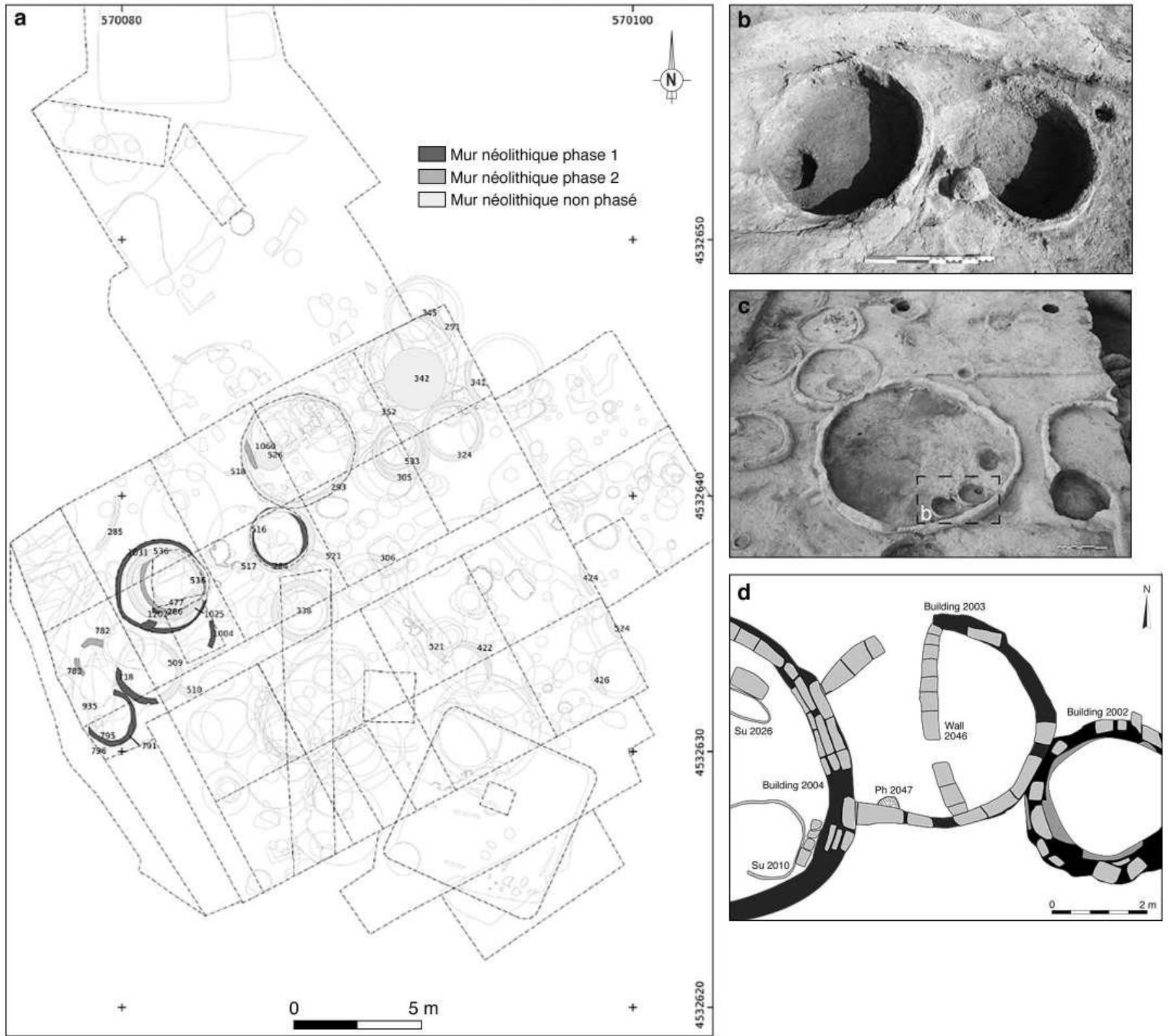

Fig. 8 -a. Mentesh Tepe, plan of the Neolithic levels (drawing E. Degorre); $\boldsymbol{b}$. Kiçik Tepe, square F9, Building 8, detail of two storage bins in the north-eastern partof the building, view from the south(Mission BoyukKesik, MEAE); . KiçikTepe, generalviewofBuilding 8 with locationofstorage bins, view from the north (Mission Boyuk Kesik, MEAE); d. Gadachrili Gora, general plan of trench 2, level I (drawing C. Hamon, E. Baudouin).

specific mud-brick foundations. In both cases, their function was to protect the walls from damp rising by capillarity and to reinforce the superstructure.

\section{Stone or clay beds under floors}

At Mentesh Tepe, the floor level of the semi-subterranean building rests on a compact silty clay levelling layer (fig. 9), probably chosen for its waterproof qualities (Houben and Guillaud 1989: 41) to avoid rising humidity, to fill the irregularity of the virgin soil and to level the ground for the layout of the floor, like in Building 795 (Baudouin et al. 2018: 57, fig. 6). At Aratashen, concentrations of pebbles have been found inside two buildings but we have no information on their layout. 


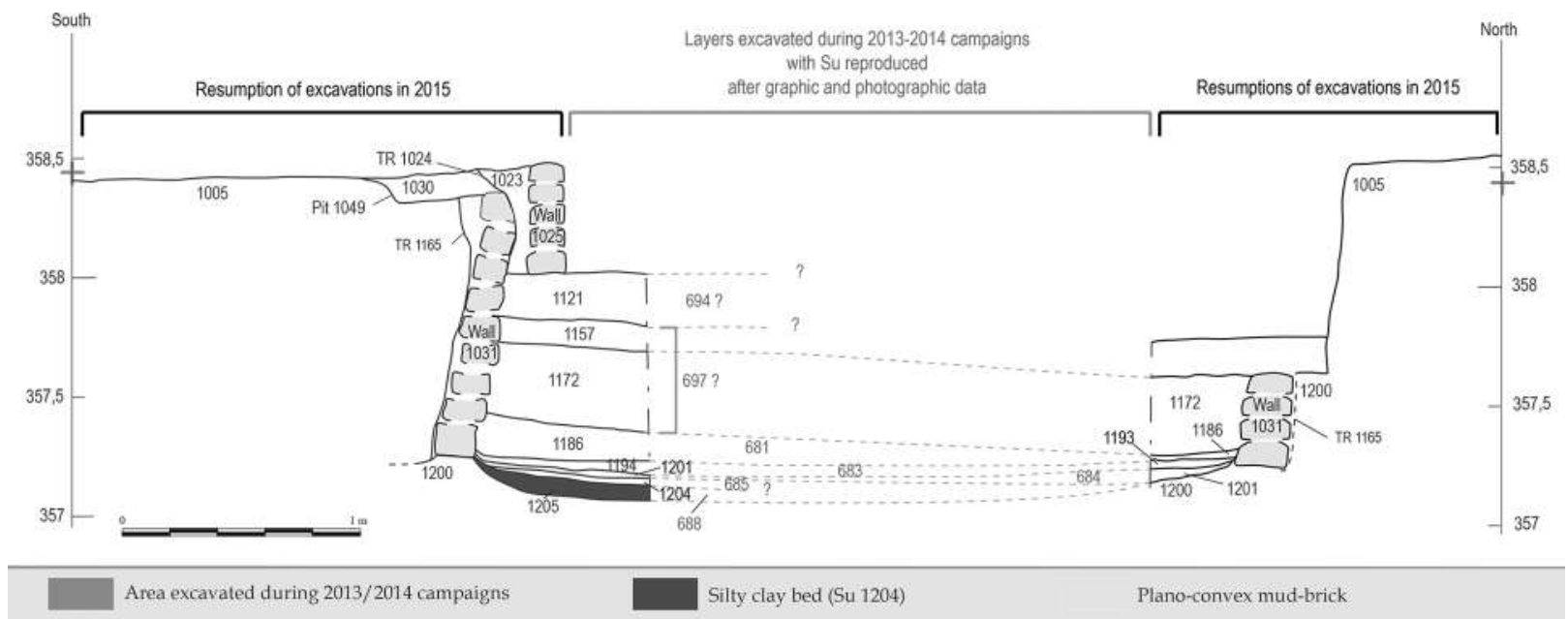

Fig. 9 - Mentesh Tepe, section south/north of Building 1031, sector 15 (Mission Mentesh Tepe; drawing E. Baudouin).

Table 6 - Layout techniques - beds, foundations, footings and terraces (E. Baudouin).

\begin{tabular}{|c|c|c|c|c|}
\hline Site & Culture/level & Building & Type & Bibliographical references \\
\hline Aratashen & $\mathrm{AC} / \mathrm{Ilc}, \mathrm{Ilb}$ & $\begin{array}{l}\text { Str. 47; } \\
\text { Str. X }\end{array}$ & $\begin{array}{l}\text { Bed under } \\
\text { floors }\end{array}$ & Badalyan et al. 2007: 41 \\
\hline Göy Tepe & SSC & & $\begin{array}{l}\text { Mud-bricks } \\
\text { foundations }\end{array}$ & Guliyev and Nishiaki 2014: 7 \\
\hline $\begin{array}{c}\text { Haci } \\
\text { Elamxanlı } \\
\text { Tepe }\end{array}$ & $\mathrm{SSC} / 3$ & Wall 75 & $\begin{array}{l}\text { Bed under } \\
\text { the wall }\end{array}$ & Nishiaki et al. 2015b: 7, fig. 2 \\
\hline Kamiltepe & $\begin{array}{l}\text { Kamiltepe/ } \\
\text { Kamiltepe I }\end{array}$ & Terrace & Terrace & $\begin{array}{c}\text { Helwing and Aliyev } \\
\text { 2017: } 14-17\end{array}$ \\
\hline $\begin{array}{l}\text { Khramis } \\
\text { Didi Gora }\end{array}$ & SSC & General & $\begin{array}{l}\text { Foundation: } \\
\text { reused of } \\
\text { walls }\end{array}$ & $\begin{array}{c}\text { Dzhavakhishvili and } \\
\text { Dzhaparidze 1975: 17, fig. } 2\end{array}$ \\
\hline Kültepe & Kültepe & General & Footing & Chataigner 1995: 60 \\
\hline \multirow{6}{*}{$\begin{array}{l}\text { Mentesh } \\
\text { Tepe }\end{array}$} & \multirow{6}{*}{ SSC/I } & 1031 & \multirow{2}{*}{$\begin{array}{l}\text { Bed under } \\
\text { floors }\end{array}$} & Personal data \\
\hline & & 795 & & \multirow[b]{2}{*}{ Baudouin et al. 2018: 56-57 } \\
\hline & & $782 / 783$ & $\begin{array}{l}\text { Bed under } \\
\text { the entire } \\
\text { building }\end{array}$ & \\
\hline & & \begin{tabular}{|l|}
$533 / 324$ \\
$526 / 305$
\end{tabular} & \multirow{2}{*}{$\begin{array}{l}\text { Foundation: } \\
\text { reused of } \\
\text { walls }\end{array}$} & Personal data \\
\hline & & $536 / 286$ & & Lyonnet et al. 2016: 172 \\
\hline & & 718 & Footing & $\begin{array}{l}\text { Baudouin 2017: 155, fig. 2; } \\
\text { Baudouin et al. 2018: } 56\end{array}$ \\
\hline
\end{tabular}

\section{Cobble beds under the wall and floors}

At Mentesh Tepe, two preliminary cobble beds were arranged before the installation of some buildings (Baudouin et al. 2018: 56-57, fig. 4). Both layers were used to level the building surface area and to protect the floors and walls from rising damp. At Haci Elamxanlı Tepe (fig. 10) a wall was built on a layer of cobbles, probably arranged to reinforce the wall installed over a large and soft ashy pit.
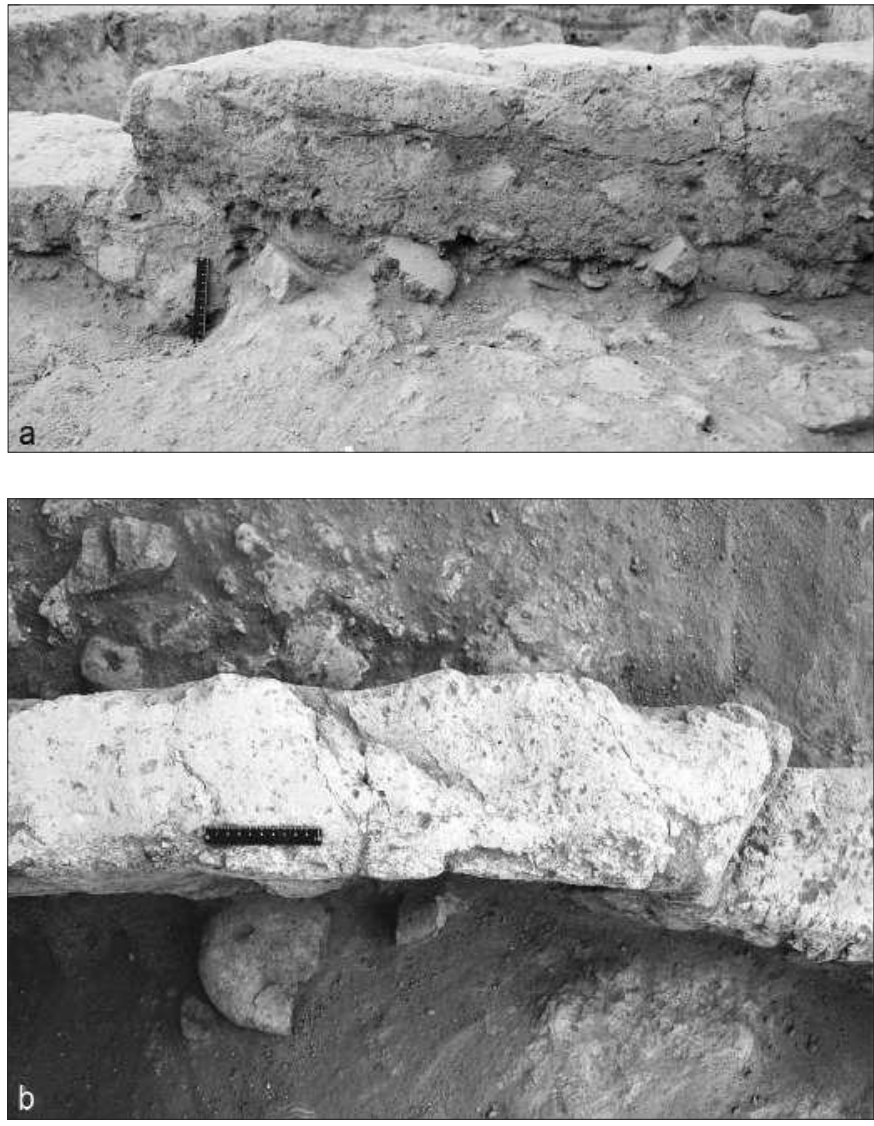

Fig. 10 - Haci Elamxanl Tepe, Wall 75, square M10 (courtesy Y. Nishiaki). a. Cobble bed under Wall 75, view from the north; b. The same cobble bed under Wall 75, view from the top. 


\section{Foundations: reused walls}

The levelling of previous construction layers is a common practice in the Near East (Aurenche 1981: 104; Sauvage 1998: 51): after the abandonment of a previous building its volume is filled up to the height of the levelling course. The identification of this layout is difficult and depends heavily on the quality of the documentation made during excavations and on a careful interpretation of the stratigraphic sequences. Indeed, it can be easily confused with a phase of reuse of the previous buildings. Three examples are clearly attested at Mentesh Tepe, and others at Khramis Didi Gora.

\section{Mud-brick foundations}

Evidence of mud-brick foundations is rare in the Southern Caucasus. Only one example is visible at Göy Tepe: a massive one-metre thick wall, located on the edge of the settlement, was built on a thick mud-brick foundation which protruded from the wall by $15-45 \mathrm{~cm}$. According to Y. Nishiaki, this installation could be assimilated to a platform (Guliyev and Nishiaki 2014: 7). ${ }^{16}$

\section{Superstructures}

Superstructures designate the architectural elements present above the ground level. The functions of these installations are similar to infrastructures (see above).

\section{Footings}

The footing (Aurenche 1977: 160-161) is often made of a different material to the rest of the elevation. Its function is to raise the base of the wall (Pérouse de Montclos 2004: 164, col. 80) and to protect it from rising moisture by capillarity (Margueron 1985). Such a layout is documented at Mentesh Tepe (Baudouin 2017: 155, fig. 2) and Kültepe.

\section{Terraces}

Terraces designate built platforms (Aurenche 1977: 166) generally intended to support a building. The only clear example known in the Southern Caucasus is that of Kamiltepe, where a circular platform has been recovered $(24 \mathrm{~m}$ in diameter, $2.6 \mathrm{~m}$ preserved height). Entirely constructed using mud-bricks, it was erected directly onto the virgin soil, requiring occasional levelling work (Helwing and Aliyev 2017: 17). No installation could be identified at the top of the terrace, but a set of rooms was arranged around it (Helwing and Aliyev 2017: 18, fig. 10).

\footnotetext{
16. The location in the foundations leads us to distinguish this layout from
} real terraces (see below).

\section{Bonds}

Bonds designate the way in which the masonry elements are assembled.

\section{Stretcher bond}

The stretcher bond consists of juxtaposing masonry elements with the longest face of the mud-bricks along the axis of the wall (Aurenche 1981: 132). This type of bond is the oldest and most widely represented in our corpus.

This layout is attested in all the buildings at eight sites (table 7). The only variation is found in the number of rows of mud-bricks in the thickness of the wall, most commonly one (fig. 3a and d) but reaching up to three rows in rare cases (fig. 3b).

\section{Stretcher and header bond}

The header bond consists of juxtaposing masonry elements with the longest face of the mud-brick set along the width of the wall (Aurenche 1977: 39). Generally, the stretcher and header bonds consist of alternating the stretcher bond on one course and the header bond on the other.

Only three examples of stretcher and header bond have been documented (Göy Tepe, Kamiltepe and Toïre Tepe). At Kamiltepe, the mud-bricks of the terrace core are arranged alternately in stretcher and header bonds from one course to the other (Aliyev and Helwing 2009: 38, fig. 21).

\section{Absence of quoin bonding}

Quoin bonding is the joining of two walls, the components of which are linked from one course to the next (Pérouse de Montclos 2004: 110).

Quoin bonding does not seem to have been mastered by the communities of Southern Caucasus (table 6) ${ }^{17}$. At Gadachrili Gora, the cross-wall of Building 2003 is not bonded to the peripheral wall, which itself leans against the exterior face of Building 2004. At Imiris Gora, the peripheral wall of Building 8 leans against the wall of Building 9-10. Inside Building 8, pilasters, which materialise the entrance of the building, are not bonded to the peripheral wall. At Mentesh Tepe, as at Haci Elamxanlı Tepe (Y. Nishiaki, personal communication) and

17. Until recently, some scholars argued that the occurrence of quoin bonding was contemporary with that of orthogonal architecture at the beginning of the PPNB period ( $7^{\text {th }}$ millennium BC) in the Near East (Sauvage 2009: 197). But at Jerf el-Ahmar (Syria), the quoin bonding from level II/E in the round buildings (Stordeur 2015: 175, table 4) testifies the prior use of the technique compared to the rectangular architecture. It can be considered as an autonomous technical stage related to the need to reinforce masonry. 
Table 7 - Layout techniques - bonds (E. Baudouin). N: no; NS: not specified; $\boldsymbol{S}$ : stretcher; $\boldsymbol{S H}$ : stretcher and header; $\boldsymbol{Y}$ : yes.

\begin{tabular}{|c|c|c|c|c|c|c|}
\hline Site & Culture/level & Building & Bond & Number of rows & Quoin bonding & Bibliographical references \\
\hline Aruchlo & SSC & & NS & & $\mathrm{Y}$ & Hansen and Ullrich 2017: 201 \\
\hline Chalagantepe & SSC & General & $\mathrm{S}$ & 1 & NS & Narimanov 1992: 45 \\
\hline \multirow{2}{*}{ Gadachrili Gora } & \multirow{2}{*}{ SSC/I } & 2002,2003 & $\mathrm{~S}$ & 1 & $\mathrm{~N}$ & Hamon et al. 2016: 160 \\
\hline & & 2004 & S & 3 & $\mathrm{~N}$ & Hamon et al. 2016: 159 \\
\hline \multirow{3}{*}{ Göy Tepe } & SSC & \multirow[b]{2}{*}{ General } & $\mathrm{S}$ & 1 & NS & Guliyev and Nishiaki 2014: 6 \\
\hline & $\mathrm{SSC} / 3-4$ & & $\mathrm{~S}$ & 3 & NS & Guliyev and Nishiaki 2014: 13, fig. 3 \\
\hline & $\mathrm{SSC} / 13$ & Massive wall in square 4B & $\mathrm{SH}$ & & NS & Courtesy Y. Nishiaki \\
\hline \multirow{5}{*}{$\begin{array}{l}\text { Haci Elamxanlı } \\
\text { Tepe }\end{array}$} & $\mathrm{SSC} / 1$ & $9,14,15$ & $\mathrm{~S}$ & \multirow{3}{*}{1} & $\mathrm{~N}$ & Nishiaki et al. 2015b: 5, fig. 4 \\
\hline & $\mathrm{SSC} / 2$ & 9,14 & $\mathrm{~S}$ & & $\mathrm{~N}$ & Nishiaki et al. 2015b: 7, fig. 6 \\
\hline & \multirow{3}{*}{$\mathrm{SSC} / 3$} & 2002,2003 & S & & $\mathrm{N}$ & \multirow{3}{*}{ Nishiaki et al. 2015b: 9 , fig. 9} \\
\hline & & 34,82 & S & 1 and 3 & $\mathrm{~N}$ & \\
\hline & & $63,65,72,75,78$ & $\mathrm{~s}$ & 2 & $\mathrm{~N}$ & \\
\hline \multirow{3}{*}{ Imiris Gora } & \multirow{3}{*}{ SSC } & General & $\mathrm{S}$ & 1 & NS & Narimanov 1992: 32 \\
\hline & & \multirow{2}{*}{$8,9-10$} & NS & & $\mathrm{N}$ & \multirow{2}{*}{$\begin{array}{l}\text { Dzhaparidze and Dzhavakhishvili 1969: } \\
\text { pl. III.2 and pl. IV.1 }\end{array}$} \\
\hline & & & NS & & $\mathrm{N}$ & \\
\hline Kamiltepe & $\begin{array}{l}\text { Kamiltepe/Phase } \\
\text { Kamiltepe I }\end{array}$ & Terrace & $\mathrm{SH}$ & & NS & Helwing and Aliyev 2017: 18 \\
\hline Kiçik Tepe & $\mathrm{SSC} / 3$ & General & S & 1 & $\mathrm{~N}$ & \multirow{2}{*}{ Personal data } \\
\hline Mentesh Tepe & SSC/I & General & $S$ & 1 & $\mathrm{~N}$ & \\
\hline \multirow{3}{*}{ Toïre Tepe } & SSC/III & 3 & S & \multirow{2}{*}{1} & NS & Narimanov 1992: 15 \\
\hline & SSC/V & 22 & $\mathrm{~S}$ & & NS & Narimanov 1992: 17 \\
\hline & SSC/II & 4 & $\mathrm{SH}$ & 1 & NS & Narimanov 1992: 15 \\
\hline
\end{tabular}

Kiçik Tepe, structures are always built adjacent to each other without the use of quoin bonding. Only at Aruchlo do the

excavators describe "walls joined and built in one action" (Hansen and Ullrich 2017: 201), and, since other non-bonded walls are also attested, they relate them to modifications in the architectural organisation during phases of the building's use.

We can also assume that in some cases the buildings were not all contemporary, which explains why later walls are not joined to the existing ones.

\section{BUILDINGS MORPHOLOGY}

This analysis takes into account all the morphological(i.e., shape, size, covering) and functional (e.g., facilities, organisation of settlements) characteristics of the buildings.

\section{Semi-subterranean architecture}

Semi-subterranean buildings are constructed by digging a pit and, often, by using the extracted earth to build low walls of stacked mud at the edge of the pit to support a wooden beam cover (Wulff 1966: 103).

In the Southern Caucasus, these buildings (called zemlianka) are geographically limited to the Kura Valley and the Mil Plain (fig. 3c and table 8). At Shomu Tepe, Aruchlo,
Mentesh Tepe and Haci Elamxanlı Tepe, they have been dug into the virgin soil. At Shomu Tepe, Narimanov (Narimanov 1987: 16) describes a semi-subterranean building filled with a variety of materials. At Baba Dervish, four "pits" were identified, all containing important material, as well as a fireplace, but no arrangement for the walls and floors is specified (Narimanov 1987: 29; Dzhavakhishvili 1973: 83). At Haci Elamxanl1 Tepe, a semi-subterranean building dug at a depth of 18 to $26 \mathrm{~cm}$ is mentioned. Even if the limit of the digging is unclear for the edge of the building (fig. 11b), the difference in height between the virgin soil inside and outside of the building leaves no doubt for its interpretation as a semi-subterranean building (fig. 11a and c; Y. Nishiaki, unpublished data). At Mentesh Tepe, the stratigraphy confirms the digging of a deep pit (fig. 9 and fig. 12g) with a terraced mud-brick wall bordering its edge (fig. 12a-b and f). The bottom was filled with a clay bed (see above), prior to the installation of floors painted in purple-red and the construction of two low internal walls of stacked mud, dividing the surface into two equal parts (fig. 12a and c-d). Many remnants of charred wood (fig. 12f), found in the level of abandonment, and the presence of two postholes may indicate the use of posts and beams for the roof of the building (fig. 12e). At Aruchlo, semi-subterranean buildings were located on the edge of the site (Ioseliani 2017b: 226-227) and possibly date to the oldest phase of occupation, before 5800 BC. In the Karabakh Plain, 
Table 8 - Buildings morphology - semi-subterranean plan E. Baudouin). N: no; NS: not specified; Y: yes.

\begin{tabular}{|c|c|c|c|c|c|c|c|}
\hline Site & Culture/level & Building & Diameter (in $\mathrm{m}$ ) & Area $\left(\right.$ in $\left.\mathrm{m}^{2}\right)$ & Depth (in m) & Supporting elements & Bibliographic references \\
\hline \multirow{3}{*}{ Aruchlo } & \multirow{3}{*}{ SSC/Pit House } & 18 & $4.1-4.6$ & 27 & & NS & \multirow{3}{*}{ Torosjan 1976: 23-27, fig. 2-3 } \\
\hline & & 16 & & 23.9 & & NS & \\
\hline & & 15 & & 13.5 & & NS & \\
\hline \multirow{4}{*}{ Baba Dervish } & \multirow{4}{*}{ SSC? } & & $3.5-5$ & 13.7 & 2.5 & NS & \multirow{4}{*}{ Dzhavakhishvili 1973: 83} \\
\hline & & & 4 & 12.6 & 0.8 & NS & \\
\hline & & & 4 & 12.6 & 0.8 & NS & \\
\hline & & & 4 & 12.6 & 0.8 & NS & \\
\hline Chalagantepe & SSC/level 405-390 m & Pit-House 71 & 3.1 & 7.6 & & NS & Azimov 2006: 50, fig. 6 \\
\hline Dangreuli Gora & & & & & & NS & Dzhavakhishvili 1973: 70-71 \\
\hline Haci Elamxanlı Tepe & $\mathrm{SSC} / 4 \mathrm{~b}$ & A & More than $5 \mathrm{~m}$ & & $0.2-0.3$ & $\mathrm{~N}$ & Courtesy Y. Nishiaki \\
\hline Kamiltepe - MPS 4 & & & 2.8 & & & NS & Helwing and Aliyev 2012: 9-10, fig. 8-9 \\
\hline Mentesh Tepe & $\mathrm{SSC} / \mathrm{I}$ & 1031 & 3.8 & & $1.5 \mathrm{~min}$ & $\mathrm{Y}$ & Baudouin et al. 2017: 43 \\
\hline Shomu Tepe & SSC & & 3 & 7.1 & 1 & NS & Dzhavakhishvili 1973: 85, 87-88 \\
\hline Toïre Tepe & SSC & & & & & NS & Dzhavakhishvili 1973: 83, 87-88 \\
\hline
\end{tabular}

at Chalagantepe, the six lower layers of the Neolithic occupation contained semi-subterranean buildings. One of them (PitHouse 71) was dug into the virgin soil. The border of the pit was covered by thick clay layers and the floor was "painted wine-red and ochre" (Azimov 2006: 20). In the Mil Plain, on the site MPS 4, a circular semi-subterranean building had a terraced wall made of mud-bricks bordering the edge of the pit on its eastern side. The material found inside indicates that the building served as a workshop for shell beads. Although the chronological attribution of Alikemek Tepesi in the Mughan Plain is still controversial, the existence in the "middle horizon" of a semi-subterranean building with walls painted with red drawings on a white background should be noted (Mahmudov 1984: 59).

\section{Above ground circular plan}

In the Near East, the circular plan tends to disappear at the end of the PPNB to the benefit of the rectangular plan. However, it still occurs in some regions during the $6^{\text {th }}$ and $5^{\text {th }}$ millennia BC, especially in the Levant (Aurenche 1981: 185, map 17), Cyprus (Le Brun 1989: 162-163) and Northern Mesopotamia, mainly within the Halaf culture (Breniquet 1996), which is contemporary with the Caucasian Neolithic. In the Southern Caucasus, apart from a few cases, the circular plan is the only architectural plan attested during the whole Neolithic period and two different types of above ground circular buildings are recorded: plain monocellular buildings and buildings with an internal partition. Far from being exhaustive, a total of 372 buildings have been taken into account in the current study (table 9).

At Shomu Tepe (fig. 13c), differences in size has led to the identification of two types of circular buildings (Narimanov
1987: 16): small with a diameter ca. $2 \mathrm{~m}$ (area of $3.1 \mathrm{~m}^{2}$ ) and large with a diameter $c a .3 .5 \mathrm{~m}$ (area of $9.2 \mathrm{~m}^{2}$ ). Narimanov also notes that the small and large buildings are linked to each other by low walls: the association of the different circular constructions around a central open area (courtyard) forming a compound. A similar organisation is attested at other sites of the SSC, as at Imiris Gora in level V (fig. 14b), Khramis Didi Gora (Menabde et al. 1978: 27, fig. 1, 33, fig. 2; Menabde et al. 1980: 21, fig. 1, 22, fig. 2), Toïre Tepe (Narimanov 1987: 207, fig. 11, 208, fig. 12, 210, fig. 14), Gargalar Tepesi (fig. 13b), Chalagantepe (Narimanov 1986: 423; Narimanov 1992: 44), Ilanlitepe ${ }^{18}$, Aruchlo (Hansen and Ullrich 2017: 209, fig. 22, 210, fig. 23) and Göy Tepe (fig. 14a), all dated from the middle or the second half of the $6^{\text {th }}$ millennium BC. In sites dated to the Early Neolithic (first third of the $6^{\text {th }}$ millennium $\mathrm{BC}$ ), the buildings are organised according to the socalled snowman-shape (Nishiaki et al. 2015b: 5), i.e., a large building adjacent to a smaller one, as at Haci Elamxanlı Tepe (fig. 13a), Gadachrili Gora (fig. 8d), Mentesh Tepe (fig. 8a), Kiçik Tepe (fig. 8c), Imiris Gora, level I in the Kura Valley and Aknashen-Khatunarkh in the Araxes Valley.

At Shulaveris Gora three functional categories for these buildings have been proposed, based upon their diameter (Dzhavakhishvili and Dzhaparidze 1975: 204): water storage facilities (less than $1 \mathrm{~min}$ diameter, area less than $0.8 \mathrm{~m}^{2}$ ), storage and domestic activities facilities (diameter $c a$. 1.3-2 m, area ca. $1.2-3.1 \mathrm{~m}^{2}$ ) and residential buildings (diameter $c a .2 .5-5 \mathrm{~m}$, area $c a .4 .9-19.6 \mathrm{~m}^{2}$ ).

18. Radiocarbon dates of these last two sites and their attribution to the SSC are nevertheless controversial. 

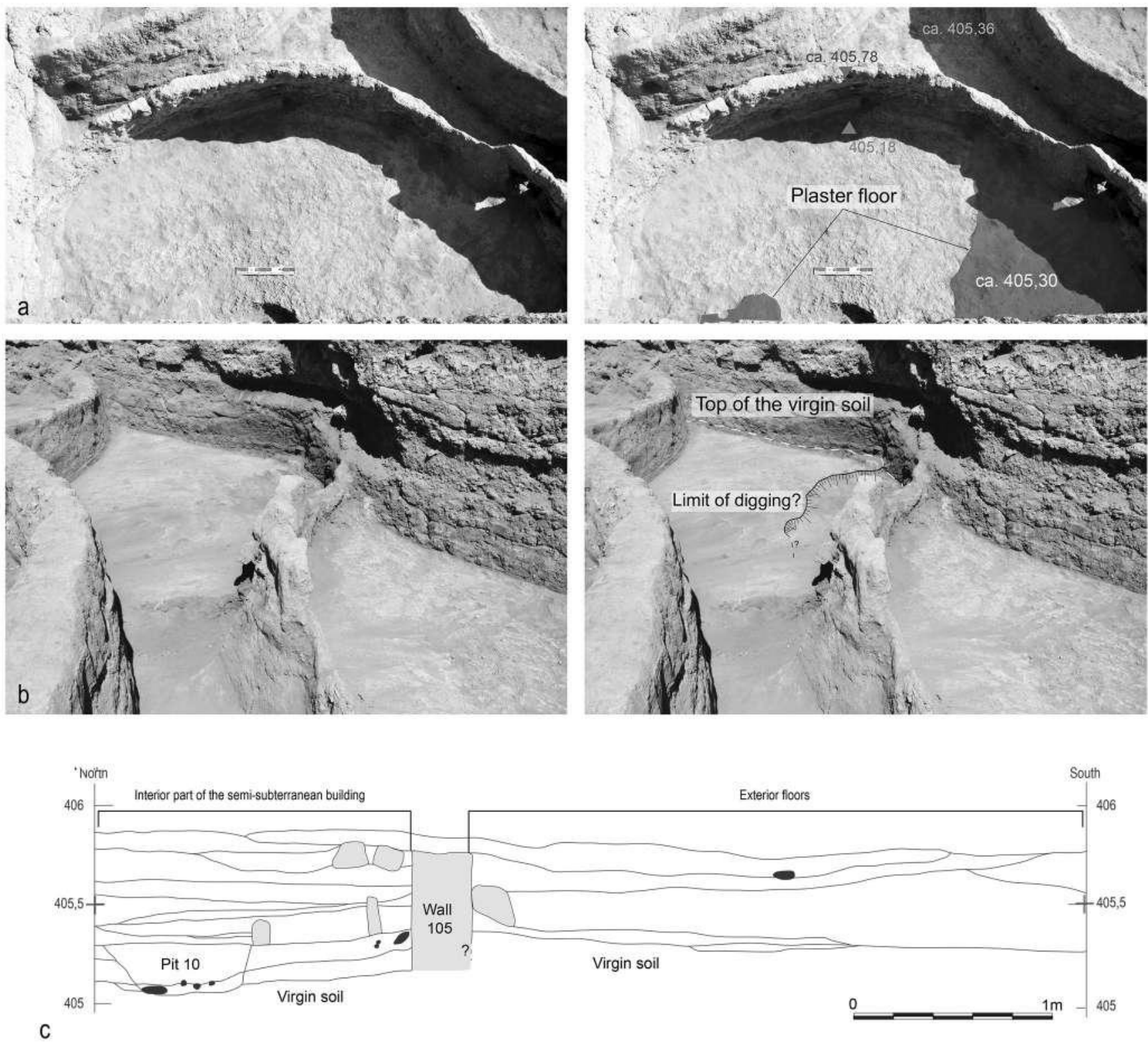

Plaster floor

Mud-bricks and wall

Stones

9,94 Low altitude

$\nabla_{9,12}$ High altitude

Fig. 11 - Haci Elamxanl Tepe, square M11, semi-subterranean building, Wall 105 (courtesy Y. Nishiaki). a. General view of the building with plaster floor on the west and central parts, view from the north; $\boldsymbol{b}$. Detail of the northern corner of the building, view from the south-east; $\boldsymbol{c}$. Section north-south of square M10 (drawing S. Kadowaki). 


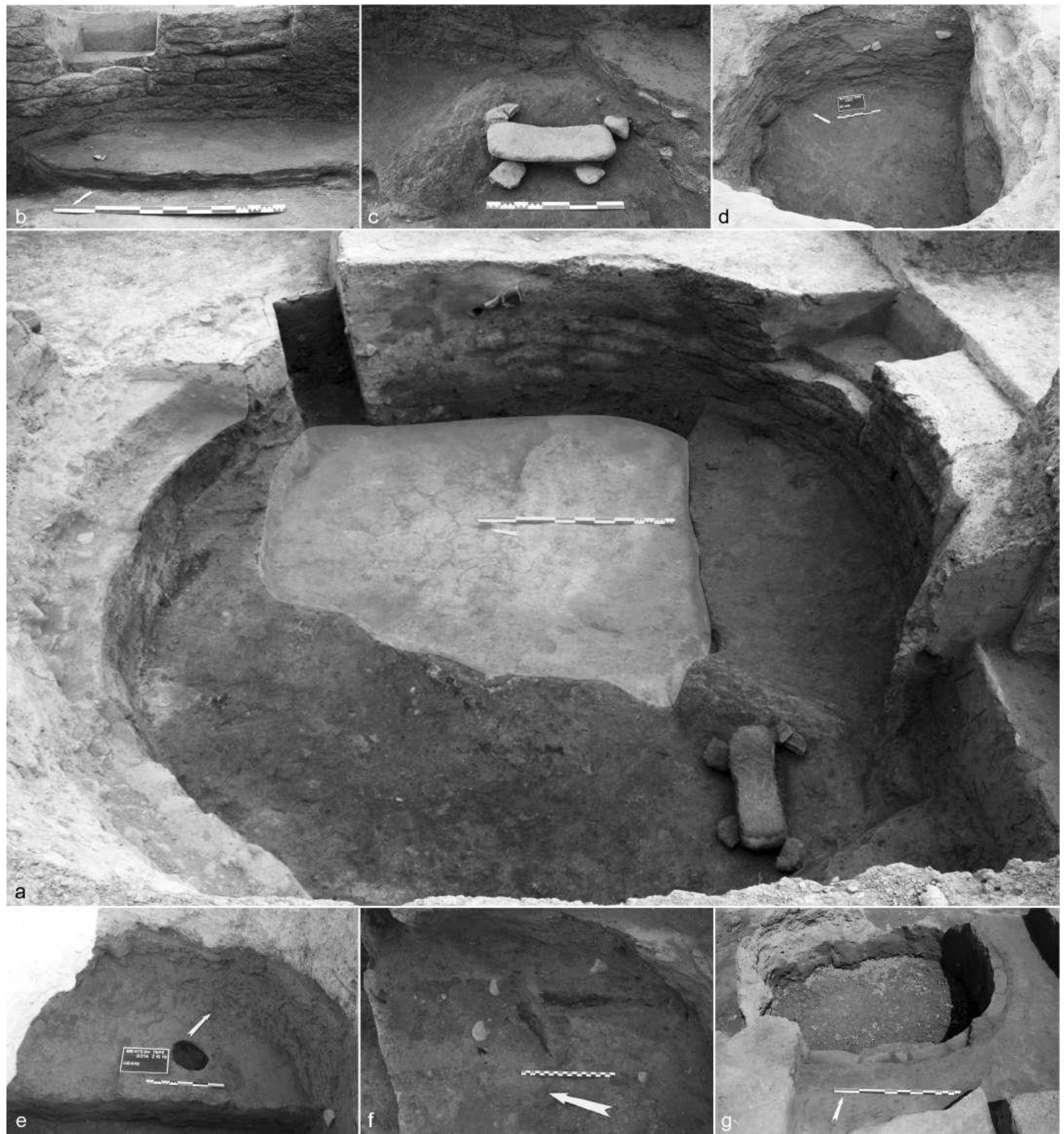

Fig. 12 - Mentesh Tepe, squares 15-16, semi-subterranean building 1031 (Mission Mentesh Tepe). a. General view of Building 1031 with, in grey, the excavated area before 2015, view from the west; $\boldsymbol{b}$. Detail of the terrace wall and the floor (SU 1204), view from the north; $\boldsymbol{c}$. Detail of a millestone in situ in the south-western part of the building, view from the north; $d$. Detail of the low walls of stacked mud, view from the south-west; $\boldsymbol{e}$. Detail of a posthole inside building 1031, view from the south; $f$. Detail of charred wood found in abandonment level (SU 1172), view from the west; $g$. General view of the limit of the digging on the top of the building, view from the south. 
Table 9 - Buildings morphology - circular buildings in superstructure (E. Baudouin). N: no; NS: not specified; Y: yes.

\begin{tabular}{|c|c|c|c|c|c|c|}
\hline \multirow[b]{2}{*}{ Site } & \multirow[b]{2}{*}{ Culture/level } & \multicolumn{4}{|c|}{ Number of buildings (and in \% by level) } & \multirow[b]{2}{*}{ Bibliographical references } \\
\hline & & $\begin{array}{c}\text { Cat. 1 } \\
\left(<5 \mathrm{~m}^{2}\right)\end{array}$ & $\begin{array}{c}\text { Cat. 2 } \\
\left(5-9 \mathrm{~m}^{2}\right)\end{array}$ & $\begin{array}{c}\text { Cat. 3 } \\
\left(9-15 \mathrm{~m}^{2}\right)\end{array}$ & $\begin{array}{c}\text { Cat. } 4 \\
\left(>15 \mathrm{~m}^{2}\right)\end{array}$ & \\
\hline Aknashen-Katunarkh & $\mathrm{AC} / \mathrm{IV}$ & 0 & 0 & 0 & $1(100)$ & Badalyan et al. 2010: 217, fig. 4.1 \\
\hline \multirow{10}{*}{ Aruchlo } & SSC/Younger Neolithic settlement & $1(16.7)$ & $3(50)$ & $1(16.7)$ & $1(16.7)$ & Hansen and Ullrich 2017: 209, fig. 22, 210, fig 23 \\
\hline & SSC/Older Neolithic settlement & $2(25)$ & 0 & $3(37.5)$ & $3(37.5)$ & Hansen and Ullrich 2017: 209, fig. 22 \\
\hline & $\mathrm{SSC} / 1$ & $2(40)$ & $1(20)$ & $2(40)$ & 0 & \multirow{8}{*}{ Ioseliani 2017b: 226, fig. 4} \\
\hline & SSC/1? & 0 & $1(100)$ & 0 & 0 & \\
\hline & $\mathrm{SSC} / 2$ & $5(50)$ & $1(10)$ & $3(30)$ & $1(10)$ & \\
\hline & $\mathrm{SSC} / 3$ & $7(58.3)$ & $2(16.7)$ & $2(16.7)$ & $1(8.3)$ & \\
\hline & $\mathrm{SSC} / 4$ & $7(58.3)$ & $2(16.7)$ & $2(16.7)$ & $1(8.3)$ & \\
\hline & SSC/5 & $3(100)$ & 0 & 0 & 0 & \\
\hline & $\mathrm{SSC} / 6$ & 0 & $1(100)$ & 0 & 0 & \\
\hline & $\mathrm{SSC} / 7$ & 0 & $1(100)$ & 0 & 0 & \\
\hline \multirow{11}{*}{ Chalagantepe } & $\mathrm{SSC} / 1(405-390 \mathrm{~m})$ & $2(40)$ & $3(60)$ & 0 & 0 & Azimov 2006: 50, fig. 6 \\
\hline & $\mathrm{SSC} / 2(390-370 \mathrm{~m})$ & $2(22.2)$ & $6(66.7)$ & 0 & $1(11.1)$ & Azimov 2006: 50, fig. 7 \\
\hline & SSC/3 (370-350 m) & $6(40)$ & $7(46.7)$ & $1(6.7)$ & $1(6.7)$ & Azimov 2006: 51, fig. 8 \\
\hline & SSC/4 (390-370 m) & $7(50)$ & $5(35.7)$ & $1(7.2)$ & $1(7.2)$ & Azimov 2006: 51, fig. 9 \\
\hline & $\mathrm{SSC} / 5(325-305 \mathrm{~m})$ & $5(55.6)$ & $3(33.3)$ & $1(11.1)$ & 0 & Azimov 2006: 52, fig. 10 \\
\hline & SSC/6 (305-290 m) & $6(50)$ & $6(50)$ & 0 & 0 & Azimov 2006: 52, fig. 11 \\
\hline & SSC/7 (290-275 m) & $7(46.7)$ & $8(53.3)$ & 0 & 0 & Azimov 2006: 53, fig. 12 \\
\hline & SSC/8 (275-255 m) & $7(58.3)$ & $5(41.7)$ & 0 & 0 & Azimov 2006: 53, fig. 13 \\
\hline & $\mathrm{SSC} / 9(255-230 \mathrm{~m})$ & $9(52.9)$ & $8(47.1)$ & 0 & 0 & Azimov 2006: 54, fig. 14 \\
\hline & $\mathrm{SSC} / 10(230-208 \mathrm{~m})$ & $7(46.7)$ & $8(53.3)$ & 0 & 0 & Azimov 2006: 54, fig. 15 \\
\hline & $\mathrm{SSC} / 11(208-190 \mathrm{~m})$ & $5(100)$ & 0 & 0 & 0 & Azimov 2006: 55, fig. 16 \\
\hline Gadachrili Gora & $\mathrm{SSC} / \mathrm{I}$ & $1(33.3)$ & 0 & 0 & $2(66.7)$ & Personal data; Hamon et al. 2016: 161-162, fig. 17, 163, fig. 18 \\
\hline \multirow{3}{*}{ Gargalartepesi } & $\mathrm{SSC} / 1$ & $4(44.4)$ & $3(33.3)$ & $2(22.3)$ & 0 & \multirow{3}{*}{ Narimanov 1992: 19-21 } \\
\hline & SSC/2 & $7(70)$ & $2(20)$ & $1(10)$ & 0 & \\
\hline & $\mathrm{SSC} / 3$ & $2(100)$ & 0 & 0 & 0 & \\
\hline \multirow{8}{*}{ Göy Tepe } & $\mathrm{SSC} / 1$ & $1(100)$ & 0 & 0 & 0 & \multirow{8}{*}{ Guliyev and Nishiaki 2014: 13, fig. 3} \\
\hline & $\mathrm{SSC} / 2$ & $3(75)$ & $1(25)$ & 0 & 0 & \\
\hline & $\mathrm{SSC} / 3$ & $3(60)$ & $1(20)$ & $1(20)$ & 0 & \\
\hline & $\mathrm{SSC} / 4$ & $5(62.5)$ & $3(37.5)$ & 0 & 0 & \\
\hline & $\mathrm{SSC} / 5$ & $4(100)$ & 0 & 0 & 0 & \\
\hline & $\mathrm{SSC} / 6$ & $1(100)$ & 0 & 0 & 0 & \\
\hline & $\mathrm{SSC} / 11$ & 0 & $1(100)$ & 0 & 0 & \\
\hline & $\mathrm{SSC} / 7$ to 13 & $1(33.3)$ & $2(66.6)$ & 0 & 0 & \\
\hline \multirow{3}{*}{ Haci Elamxanlı Tepe } & $\mathrm{SSC} / 1$ & $2(66.6)$ & 0 & 0 & $1(33.3)$ & Nishiaki et al. 2015b: 5, fig. 4 \\
\hline & $\mathrm{SSC} / 2$ & $2(66.6)$ & 0 & 0 & $1(33.3)$ & Nishiaki et al. 2015b: 7, fig. 6 \\
\hline & $\mathrm{SSC} / 3$ & $3(60)$ & 0 & $1(20)$ & $1(20)$ & Nishiaki et al. 2015b: 9 , fig. 9 \\
\hline & $\mathrm{SSC} / \mathrm{I}$ & 0 & 0 & $1(100)$ & 0 & \multirow{9}{*}{ Kiguradze 1986: 31, fig. 21} \\
\hline & SSC/II & 0 & $1(100)$ & 0 & 0 & \\
\hline & SSC/III & $1(50)$ & $1(50)$ & 0 & 0 & \\
\hline & SSC/IV & $5(35.7)$ & $4(28.6)$ & $5(35.7)$ & 0 & \\
\hline Imiris Gora & SSC/V & 0 & $1(33.3)$ & $1(33.3)$ & $1(33.3)$ & \\
\hline & SSC/VI & 0 & $1(100)$ & 0 & 0 & \\
\hline & SSC/VII & 0 & $1(33.3)$ & $2(66.6)$ & 0 & \\
\hline & SSC/VIII & $1(33.3)$ & $1(33.3)$ & 1 (33.3) & 0 & \\
\hline & $\mathrm{SSC} / \mathrm{IX}$ & $1(50)$ & $1(50)$ & 0 & 0 & \\
\hline & SSC/IX & $3(75)$ & $1(25)$ & 0 & 0 & Kiguradze 1986: 72, fig. 59 \\
\hline & SSC/VIII & $2(66.6)$ & 0 & $1(33.3)$ & 0 & Kiguradze 1986: 73, fig. 60 \\
\hline & SSC/VII & $2(100)$ & 0 & 0 & 0 & Kiguradze 1986: 74, fig. 61 \\
\hline & SSC/VI & $4(80)$ & 0 & $1(20)$ & 0 & Kiguradze 1986: 75, fig. 62 \\
\hline Khramis Didi Gora & SSC/V & $2(50)$ & $2(50)$ & 0 & 0 & Kiguradze 1986: 76, fig. 63 \\
\hline & SSC/IV & 0 & 0 & 0 & $1(100)$ & Kiguradze 1986: 76, fig. 64 \\
\hline & SSC/III & 0 & $1(100)$ & 0 & 0 & \\
\hline & SSC/II & $3(60)$ & $1(20)$ & $1(20)$ & 0 & Kıguradze 1986: /8, ilg. 65 \\
\hline & SSC/I & 0 & $2(50)$ & $1(25)$ & $1(25)$ & Kiguradze 1986: 78, fig. 66 \\
\hline & SSC/III & 0 & $1(50)$ & 0 & $1(50)$ & \\
\hline KII̧ІK Iере & SSC/II & $7(77.8)$ & $1(11.1)$ & 0 & $1(11.1)$ & Personal data \\
\hline Masis Blur & $\mathrm{AC} / \mathrm{l}$ & 0 & $1(100)$ & 0 & 0 & Hayrapetyan et al. 2014: 187, fig. 6 \\
\hline Mentesh Tepe & $\mathrm{SSC} / \mathrm{l}$ & $7(87.5)$ & 0 & 0 & $1(12.5)$ & Personal data \\
\hline Shomu Tepe & SSC & $10(58.8)$ & $4(23.5)$ & $3(17.6)$ & 0 & Narimanov 1987: fig. 3 \\
\hline Shulaveris Gora & SSC & $7(38.9)$ & $6(33.3)$ & $3(16.7)$ & $2(11.1)$ & Dzhavakhishvili and Dzhaparidze 1975: 17, pl. III \\
\hline & SSC/II & $1(100)$ & 0 & 0 & 0 & \\
\hline Toïre Tepe & SSC/III & $2(66.6)$ & $1(33.3)$ & 0 & 0 & $\begin{array}{c}\text { Narimanov 1987: 207, fig. } 11,208 \text {, fig. } 12,210 \text {, fig. 14; } \\
\text { Narimanov 1992: } 14-17\end{array}$ \\
\hline & SSC/V & $1(50)$ & 0 & $1(50)$ & 0 & Narimanov 1992: 14-1] \\
\hline
\end{tabular}



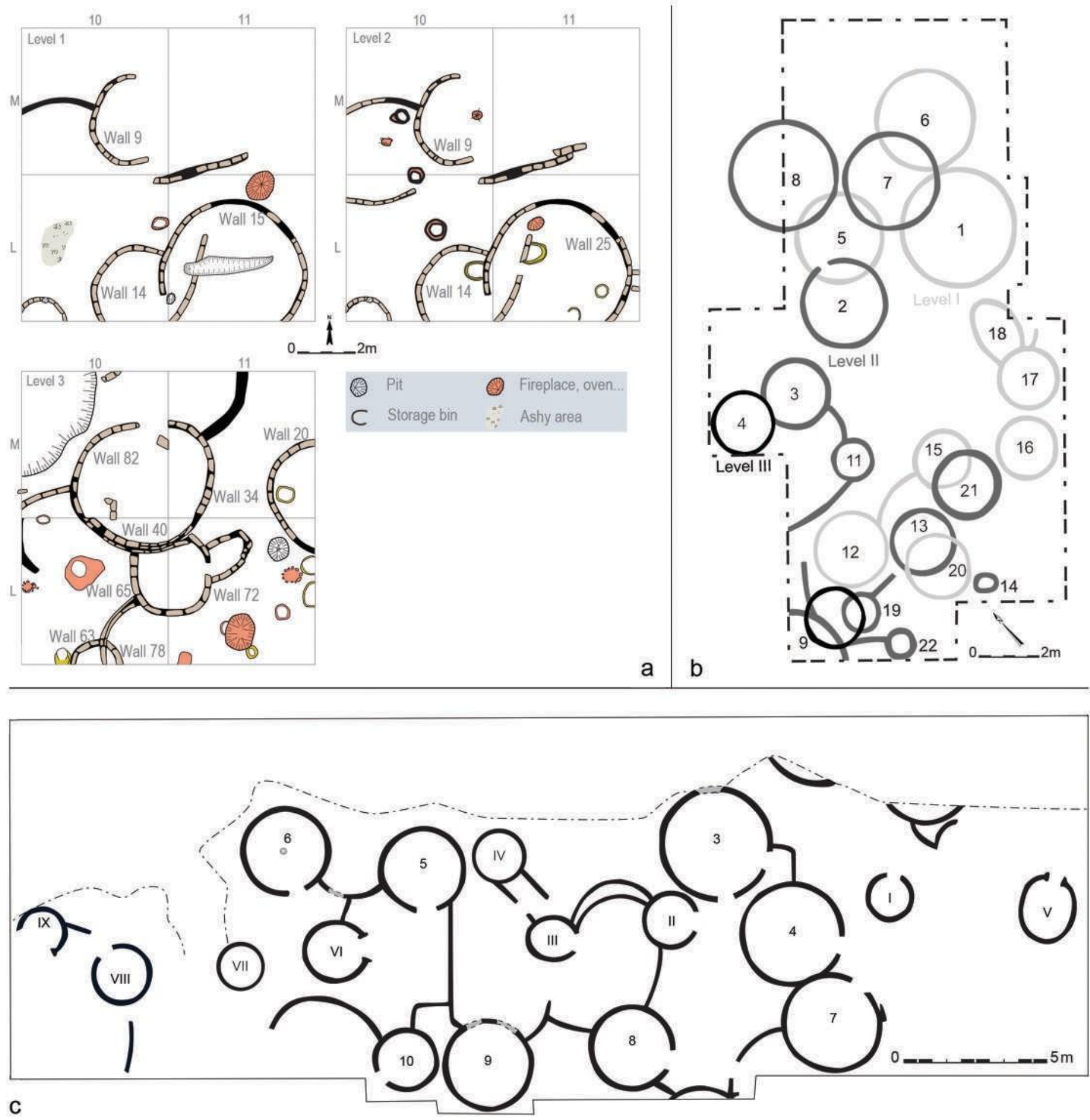

Fig. 13 - a. Haci Elamxanl Tepe, plan of levels 1 to 3 (after Nishiaki et al. 2015b: 5, fig. 4, 7, fig. 6, 9, fig. 9); b. Gargalar Tepesi, plan of levels 1 to 3 (after Narimanov 1987: 216, fig. 20); c. Shomu Tepe, plan without orientation (after Narimanov 1992: 199, fig. 3). 

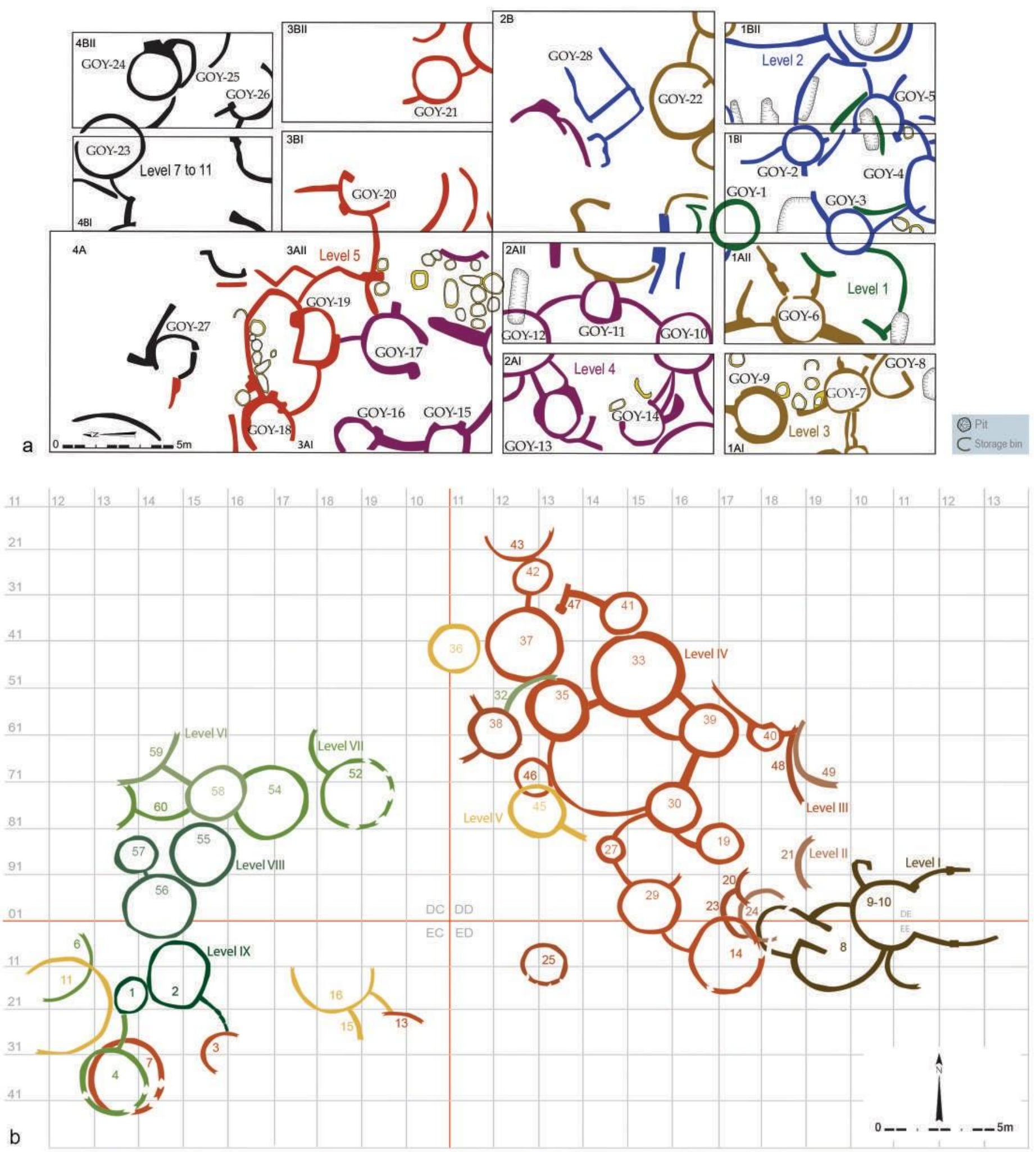

Fig. 14 -a. Göy Tepe, plan of levels 1 to 11 (after Kadowaki et al. 2015: 411, fig. 3);

b. Imiris Gora, plan of levels IX to I (based on Kiguradze 1986: 31, fig. 21). 


\section{Monocellular buildings}

I distinguished four categories based on their surface: less than $5 \mathrm{~m}^{2}$ (category 1), between 5 and $9 \mathrm{~m}^{2}$ (category 2), between 9 and $15 \mathrm{~m}^{2}$ (category 3), and larger than $15 \mathrm{~m}^{2}$ (category 4). There is a general tendency towards a reduction of the building surface area during the $6^{\text {th }}$ millennium BC (fig. 15a and table 9). ${ }^{19}$ This decrease in size is also visible at the scale of some sites such as Gargalar Tepesi, Aruchlo (between levels 1 to 7 and between the Older and Younger Neolithic Settlement), Chalagantepe, and Imiris Gora. Buildings bigger than $15 \mathrm{~m}^{2}$ (diameter of $4.5 \mathrm{~m}$ ) are mainly attested at the most ancient sites, before $5800-5700 / 5600 \mathrm{BC}$, but are not present afterwards when compounds appear (see above).

Storage facilities are predominant inside the buildings during the first third of the $6^{\text {th }}$ millennium BC, as at Haci Elamxanlı Tepe (Nishiaki et al. 2015b: 5, fig. 4.7, fig. 6), Kiçik Tepe (fig. 8b-c, fig. 16a and c-d) and Gadachrili Gora (Hamon et al. 2016: 162, fig. 14-15), but they are located in the courtyard of the compounds after this period, as it is attested at Göy Tepe (Guliyev and Nishiaki 2014: 6), Shulaveris Gora and Khramis Didi Gora, starting with level III. At Shulaveris Gora (Chataigner 1995: 61), Khramis Didi Gora (Kiguradze 1986: 47) and Imiris Gora (Dzhavakhishvili 1973: 24-25), hearths and fireplaces are always located inside the buildings, while combustion facilities such as at Göy Tepe (Guliyev and Nishiaki 2014: 6) are usually identified outside of the buildings.

\section{Circular building with interior division}

At Kiçik Tepe, a partition wall divides Building 2 in two parts (fig. 16a). Unfortunately, due to significant erosion in the western flank of the site, it was not possible to restore the organisation of the western part of the building. At Gadachrili Gora, the building was divided into two equal parts by a north/ south mud-brick wall, located to the east of the northern and southern entrances (fig. 17b). Its $20 \mathrm{~cm}$ conservation height corresponds to its initial stage because the floor level rests on top of this low wall. The section (fig. 17a and c) showed a sudden break in the floor level, west of the wall, a likely indicator of a kind of crawl space, possibly an elevated floor, perhaps installed on pilettes in perishable materials.

To sum up, the evolution of the architectural organisation, from the snowman-shape to compounds, is confirmed at most of the sites with sound stratigraphic evidence. This change can be dated to the end of the first third of the $6^{\text {th }}$ millennium $\mathrm{BC}$,i.e.,

19. Only the Khramis Didi Gora site testifies to the inverse phenomenon of an increase in surface area. A review of the stratigraphy would certainly allow us to understand the reason for this phenomenon. contemporary with the disappearance of the larger buildings. This change also seems linked to a shift in domestic activities (Kadowaki et al. 2015: 423), carried out inside of the domestic structures in the oldest settlements and outside (but still in the interior of the compounds) from the middle of the $6^{\text {th }}$ millennium BC. For the oldest buildings, it was not possible to distinguish the building functions according to their size because facilities are located both in small and large buildings (fig. 15b).

\section{Covering and roofing}

For a long time, archaeologists have proposed a dome-shaped (or beehive-shaped) roof, for the Neolithic buildings of the Southern Caucasus (Dzhavakhishvili andDzhaparidze 1975:26). The presence of a pronounced internal batter has often guided these interpretations, as at Shulaveris Gora, where it is understood as the departure of a corbelled vault (Dzhaparidze and Dzhavakhishvili 1971: 110).

Recently, F. Guliyev and Y. Nishiaki have emphasised the impossibility of a beehive coverage because of the thinness of the walls (Guliyev and Nishiaki 2014: 6). In other cases, a flat roof had been restituted thanks to the presence of postholes such as at Imiris Gora (Dzhavakhishvili and Dzhaparidze 1975: pl. XV, fig. 1) and Khramis Didi Gora. Wooden poles have also been identified at Göy Tepe (Guliyev and Nishiaki 2014: 5) and Aruchlo (Hansen and Ullrich 2017: 203). At Mentesh Tepe, the discovery of three postholes near the mud-brick wall, and of one pole imprint in the central part of the larger building enabled us to restore a system of supporting posts, and to reconsider the hypothesis of a curtain wall function for the mud-brick perimeter wall (Baudouin et al. 2017: 44, 46, fig. 5; Baudouin et al. 2018: 61). At Kiçik Tepe, the good preservation of Building 2 (fig. 16b) led to the restitution of part of its elevation (table 10). According to the archaeological (Margueron 1987) and ethnographic dataset (Houben et al. 2006: 279), it is possible to restore an overall height of $c a .3 .2 \mathrm{~m}$ for this building.

\section{DISCUSSION}

The difference between a circular and rectangular plan has been used in the past to distinguish between nomadic and sedentary populations (Whithing and Ayres 1968; Flannery 2002). Although circular architecture is deemed to be the preferred plan for temporary occupations and mobile populations, its use does not exclude more stable occupations. This latter hypothesis deserves to be examined in detail, especially considering that 


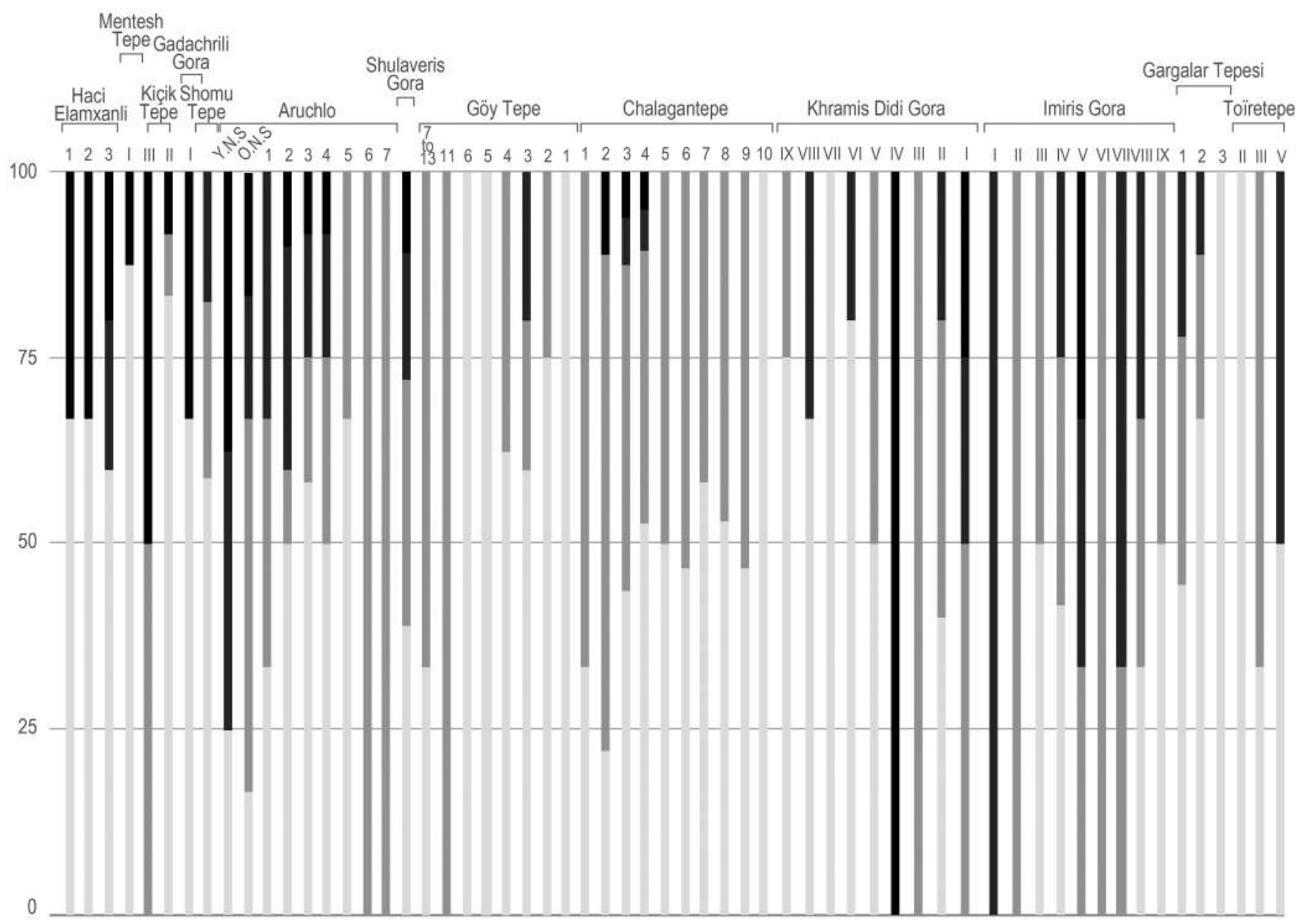

a

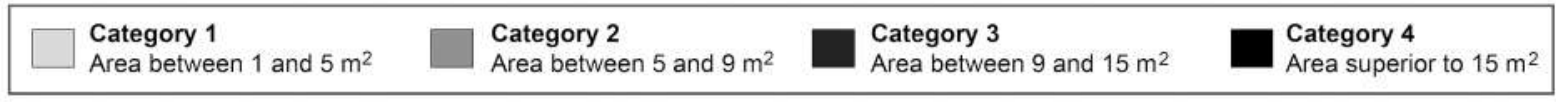

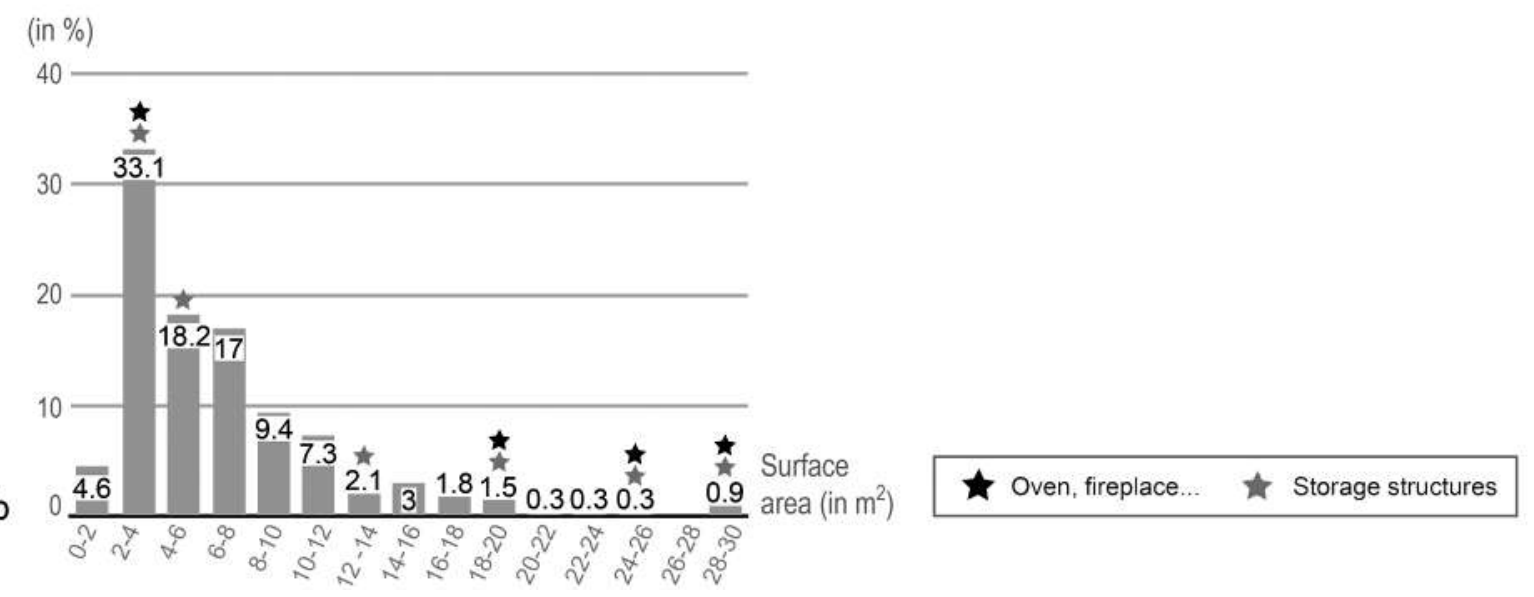

Fig. 15 -Building's surface areas (E. Baudouin). a. Summary diagram of the building's surface areas in the $6^{\text {th }}$ millennium BC, expressed as a percentage; $\boldsymbol{b}$. Distribution of circular buildings according to surface area, expressed as a percentage. 


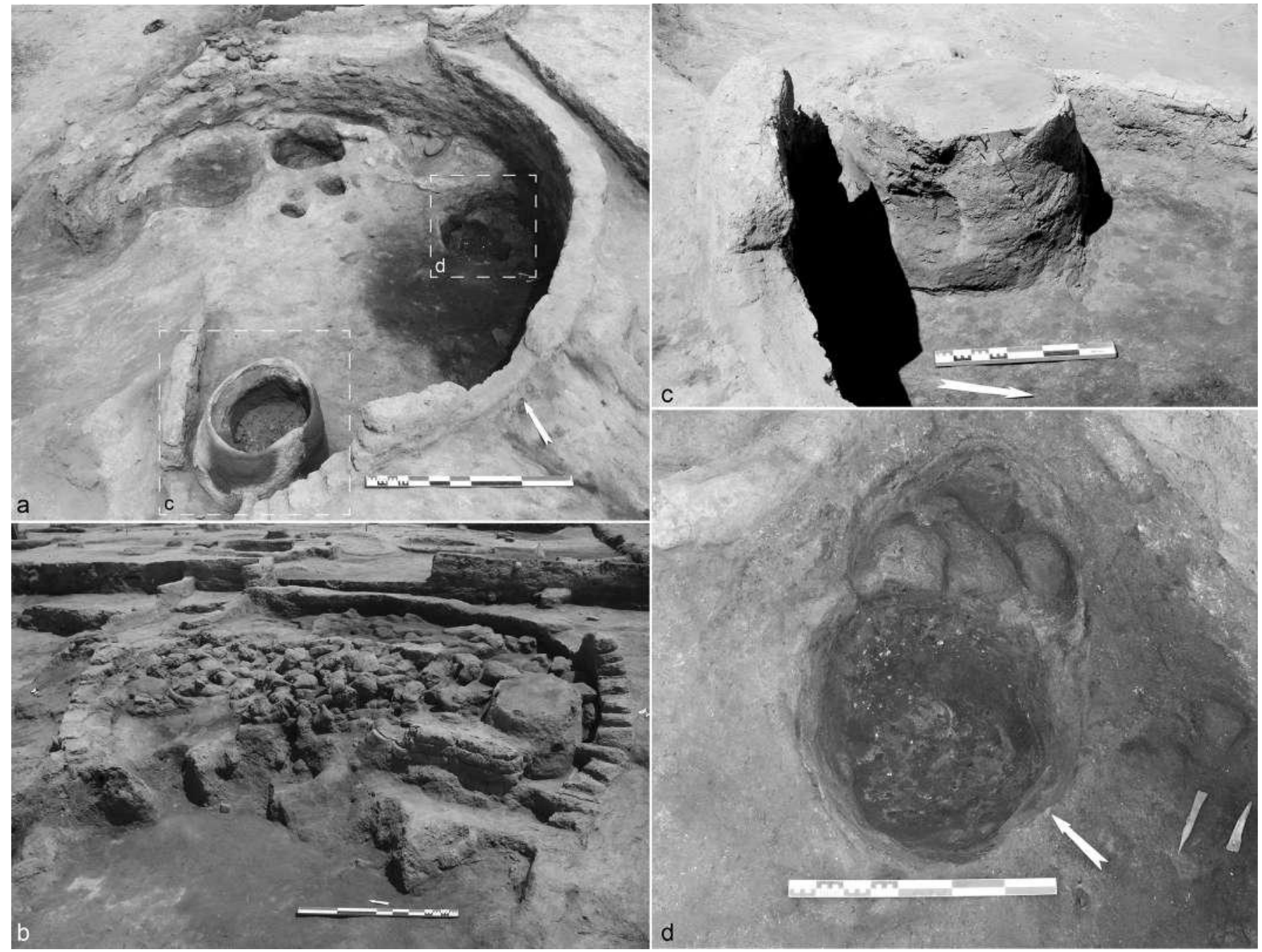

Fig. 16 - Kiçik Tepe, square H8, Building 2 (photo mission Boyuk Kesik, MEAE). a. General view of Building 2 with location of structures, view from the south; $\boldsymbol{b}$. The collapsed layer of mud-bricks and roof remains, view from the south-west; $\boldsymbol{c}$. Storage bin (USC 19) in the southern part of the building, view from the east; $d$. Fireplace $(F y-5)$ in the eastern part of the building, view from the southwest.

the circular plan is the only plan attested in a large area of the Southern Caucasus for more than seven hundred years. This apparent technical inertia in architecture could also be related to the absence of knowledge of quoin bonding and, more generally, of the technical evolution of bonds.

\section{ARE ROUND HOUSES A CLUE FOR MOBILITY IN THE SOUTH CAUCASIAN NEOLITHIC?}

At several sites (Mentesh Tepe, Imiris Gora, Khramis Didi Gora, Göy Tepe), the repeated reconstruction of buildings in the same place has been observed, which suggests a "temporary" but regular occupation of the same place. Nevertheless, the duration of occupation remains difficult to quantify (a few months? one year? several years?). Recent research at Göy Tepe has made it possible to estimate the occupation duration of the circular buildings to be between five and fifteen years (Nishiaki et al. 2018: 125-126).

The debate on the relations between mobility and circular architecture stems from an analogous discussion on the sedentary lifestyle of Halafian populations which often feature a circular house plan (Pollock 2013). In this latter case, the hypothesis of populations attached to several seasonal places 

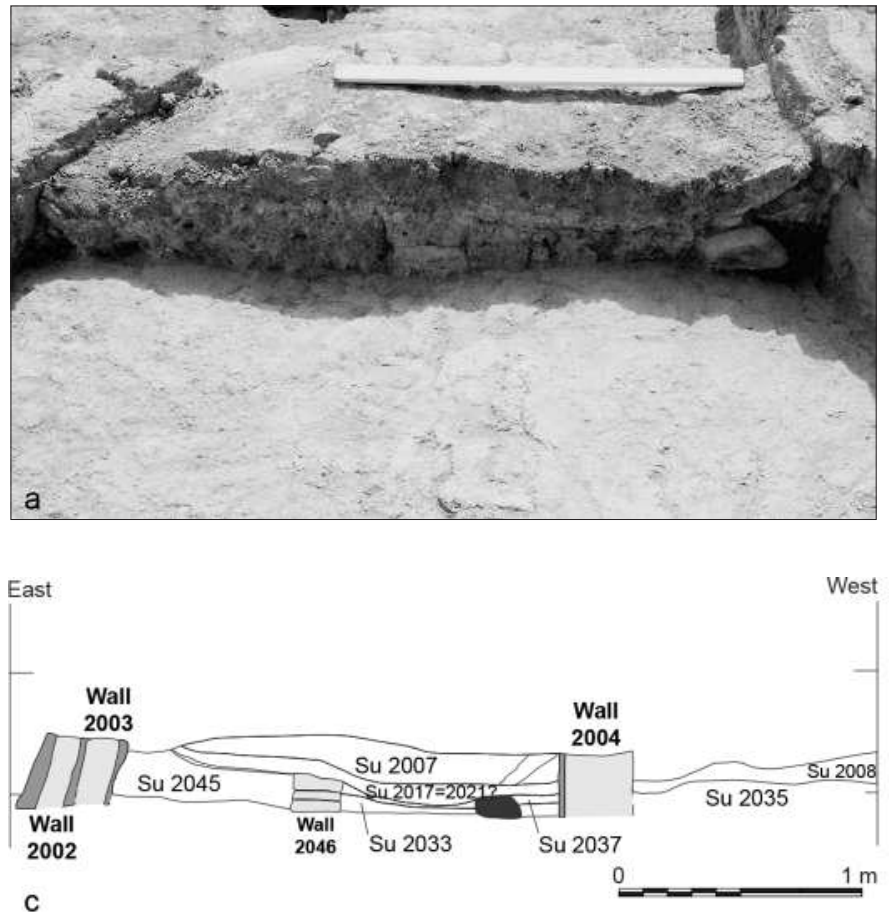

Mud-brick walls $\square$ Stones $\square$ Plaster

Table 10 - Summary table of measurements for the restitution of the elevations of Building 2 at Kiçik Tepe (E. Baudouin).

\begin{tabular}{|l|c|}
\hline External diameter (in m) & 5.3 \\
\hline Overall surface area (in $\mathrm{m}^{2}$ ) & 22.06 \\
\hline Internal diameter (in $\mathrm{m}$ ) & 4.8 \\
\hline Usable surface area (in $\mathrm{m}^{2}$ ) & 18.1 \\
\hline Height of the preserved mud-brick wall (in $\mathrm{m}$ ) & 1.3 \\
\hline Height of the preserved collapse layer (in $\mathrm{m}$ ) & 0.6 \\
\hline Overall volume of the building (in $\mathrm{m}^{3}$ ) & 28.68 \\
\hline Usable volume of the building (in $\mathrm{m}^{3}$ ) & 23.52 \\
\hline Volume of the preserved mud-brick wall (in $\mathrm{m}^{3}$ ) & 5.16 \\
\hline Volume of the collapse layer inside the building (in $\mathrm{m}^{3}$ ) & 10.86 \\
\hline Presumed overall volume of the collapse layer (in $\mathrm{m}^{3}$ ) & 14.48 \\
\hline Presumed thickness of the roof (in m) & 0.3 \\
\hline Presumed volume of the roof (in $\mathrm{m}^{3}$ ) & 8.2 \\
\hline Presumed volume of the collapse (mud-bricks and roof) (in $\mathrm{m}^{3}$ ) & 6.28 \\
\hline Presumed volume of the collapsed mud-brick wall (in $\mathrm{m}^{3}$ ) & 3.55 \\
\hline Presumed height of the missing elevation (in $\mathrm{m}$ ) & 1.58 \\
\hline Presumed height of the overall elevation (in $\mathrm{m}$ ) & 2.88 \\
\hline
\end{tabular}

has been advanced in place of sedentariness. Mobility could have been linked to an economy founded on cyclical agriculture, although that does not necessarily exclude that part of the community was sedentary (Bréniquet 1996: 62).

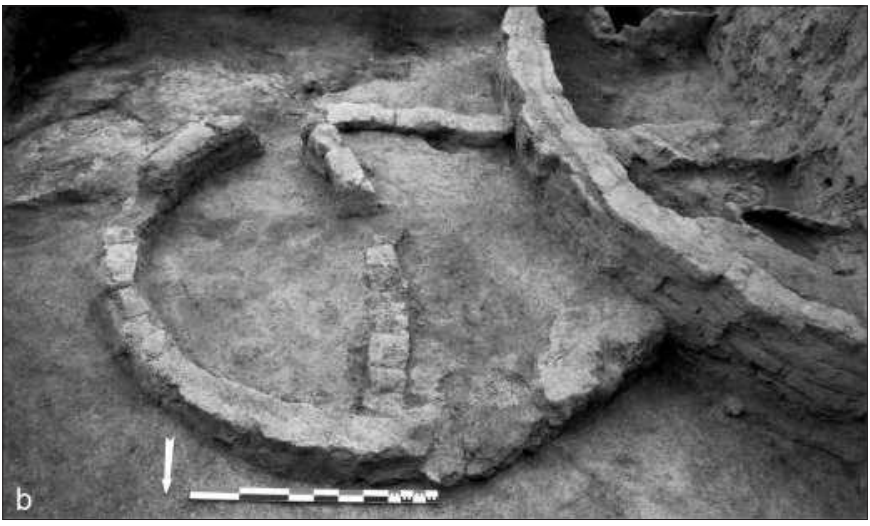

Fig. 17 - Gadachrili Gora, Building 2003, trench 2: a. View of the south baulk in Building 2003, before excavation, view from the north (C. Hamon); b. General view of Building 2003 with Wall 2046 in the centre, view from the north (after Hamon et al. 2016: 162, fig. 17);

c. East-west section of Building 2003 (drawing E. Baudouin).

In the Southern Caucasus, the seasonal occupation of settlements can be explained through two different perspectives: 1) the seasonal mobility of livestock leading to the practice of transhumance (Badalyan et al. 2010) ${ }^{20}$; indeed, indirect evidence of the transhumant lifestyle led by the South Caucasian communities could also be argued through the exploitation of obsidian in the highland mountains (Chataigner and Gratuze 2013); and 2) the abundant presence of in situ artefacts, like usable tools on the floors at Göy Tepe (Nishiaki et al. 2018: 128), or in caches "to store important items for future use" (Nishiaki et al. 2018: 129) at Göy Tepe, Aratashen (Badalyan et al. 2004: 402-404), Aknashen-Katunarkh (Badalyan et al. 2010: 189-190), Aruchlo (Hansen et al. 2007: 6), Haci Elamxanlı Tepe (Nishiaki et al. 2015b: 14) and Kiçik Tepe (see n. 6), which could point, according to ethnoarchaeological studies, to a shorter period of absence (Graham 1993).

\section{DEFINITION OF "HOUSE" AND THE CHANGE IN THE SETTLEMENT PATTERNS}

The concept of "house" is important in this study and relies on ethnographic parallels which shed light on the multipurpose use of built space. In the Kasena communities in Burkina Faso and Ghana, the "house" consists of a set of circular or

20. A programme of isotope analysis on animal teeth from Mentesh Tepe and Kamiltepe headed by M. Mashkour (Museum national d'Histoire naturelle, Paris) is in progress. 
rectangular rooms (compound) grouped around a courtyard or scattered across an open area (Liberski-Bagnoud 2002: 67-73). In the case of courtyards, these include the bulk of domestic activities with storage facilities. If the "inside" and "outside" notions are pregnant, they do not exclude a certain porosity, as is the case for ritual-related rooms or meeting rooms, located physically outside of the "house" but considered as an integral part of it. Finally, these compounds are scattered within a sparse village complex (Liberski-Bagnoud 2002: pl. I).

During the Neolithic in the Southern Caucasus it is important to note an evolution of the house cells, moving from a snowman-shaped plan to a more complex organisation of compounds. This change in the organisation of the household could be related to the abandonment of the older small settlements, such as Gadachrili Gora or Kiçik Tepe, whose surface area was less than 1 ha, to the benefit of larger settlements, such as Göy Tepe or Khramis Didi Gora whose area reached 4-5 ha.

This transformation of settlement patterns could be explained by population pressure (Dzhavakhishvili 1973: 11). The absorption of the population into larger settlements corresponds to a different evolutionary pattern from the Halaf one, where population pressure could have been absorbed by the dynamics of segmentation, visible in an increase of small settlements. According to the typology proposed by C. Meillassoux (1975) and adapted by J.D. Forest (1996: 35) for the Near East, the organisation of the Halafian communities is "segmentary", while that of Caucasian communities would have been "integrated", as reflected by an increase in the size of the households living in the compounds. The disappearance of large and snowman-shaped buildings could have been a result of a change in the social organisation. This change may explain the withdrawal of the family unit from compounds because domestic activities are now taking place in and around the courtyards.

\section{MEANING OF SEMI-SUBTERRANEAN ARCHITECTURE}

Semi-subterranean architecture is a well-known phenomenon in archaeology and ethnography. It is usually associated with communities (Aurenche 1981: 101) who have recently adopted a sedentary way of life. For instance, the practice of digging soil to build a house is documented in the Near East during the Kebaran and Natufian (Aurenche 1981: 101). Some scholars have suggested that this solution was adapted to cultures with a limited building knowledge and not yet fully developed construction techniques (Cauvin 1978: 23; Aurenche 1981: 98).
Several ethnographic studies corroborate these interpretations. In Ghab (Syria), the correlation between historical (successive stages of settlement), natural (adjustment to the way of life and the environment) and social (different livelihoods) factors are essential to understand the establishment of semi-subterranean buildings of formerly nomadic populations fromthemountainstothe Jélémé Gulf(Thoumin 1936: 488-489). Similar accounts describe the winter huts (debbadé) of Bedouin tribes in the Syrian Middle Euphrates (Daker 1984).

In the Southern Caucasus, at Aruchlo, Mentesh Tepe and Haci Elamxanlı Tepe, it is clear that these installations date to the earliest occupation phases. Nevertheless, at both Mentesh Tepe (Lyonnet et al. 2017) and Haci Elamxanlı Tepe (Y. Nishiaki, unpublished data) semi-subterranean buildings are contemporary with the above ground buildings. The diffused presence of the semi-subterranean architecture in the Kura Valley at the beginning of the Neolithic and the absence, up until now, of an earlier phase of the "settled" history in the region could point to an autonomous genesis of this architectural technique in the region. This, however, does not exclude relationships with neighbouring regions. What is more, if we consider the use of plano-convex mud-bricks from KvemoKartli and the Kura Valley (SSC) up to the Mil Plain (Kamiltepe culture), a common origin for the communities of the region may also be suggested: that they participated in the same regional network (Kadowaki et al. 2015: 423).

\section{CONCLUSIONS}

Architecture is an original approach to the questions on the Neolithisation process in the Southern Caucasus and for understanding the cultural dynamics in the region. Architectural data allows for new considerations on the South Caucasian Neolithic communities to be proposed. From this multiscale typo-technological approach, it is possible to determine the content of the technical exchanges between the Caucasian communities and to emphasise the convergences and differences that characterise the evolution of architecture in the region.

First of all, common architectural techniques link all the Southern Caucasus communities; this is the case of the stretcher bond, the circular plan and the recurrent lack of quoin bonding. These elementary techniques point to the similar and basic technical level of these communities. Although we have observed changes in the building layouts (from the snowmanshape to the compounds at the end of the first third of the $6^{\text {th }}$ millennium BC, or the gradual reduction of the building's 
size and gradual standardisation of mud-bricks during the $6^{\text {th }}$ millennium BC), no real technical evolution is documented. At the scale of the Southern Caucasus, these convergences define similar requirements and technical skills; thus, marking the existence of a rather homogeneous "techno-cultural" entity.

Moreover, we noticed regional features characterising the Araxes (cob), the Kura Valley (plano-convex mud-bricks, semi-subterranean buildings) and the Mil Plain (terrace).

These particularisms could testify to a cultural splitting, while privileged relationships were maintained between the

Ararat Plain and the Kvemo-Kartli Plain. These regional differences question the presumed integrity or unity of the

Neolithic phenomenon in the Araxes, Kvemo-Kartli and Middle Kura valleys (Badalyan and Harutyunyan 2014: 161). This evidence allows us to consider the Southern Caucasus as a segmented geographical area within which distinct "techno-cultural" entities developed and technical similarities were the possible result of networks of exchange between neighbouring communities.

The use of semi-subterranean architecture in the Middle Kura Valley represents a key element to propose autonomous sedentarisation in the Southern Caucasus, apart from the Near East developments. ${ }^{20}$ In addition, the cultural isolation of the Caucasian communities could also be due to their geographical position, although it is clear that sporadic relationships existed at least since the beginning of the $6^{\text {th }}$ millennium $\mathrm{BC}$, as evidenced by the presence of ceramics with a "Mesopotamian" style at several South Caucasian sites.

To conclude, the study of architecture is a driving force to understand evolutive dynamics within sedentary communities. The results presented here are a first stage in the study of the Neolithic architecture in the Southern Caucasus and several questions will need to be reconsidered along with further excavations, especially as far as the origins and development of earthen materials are concerned.

\section{ACKNOWLEDGMENTS}

I would first like to thank B. Lyonnet (CNRS, UMR 7192), C. Hamon (CNRS, UMR 8215) and G. Palumbi (CNRS, UMR 7264) for their academic support and for allowing me to study the unpublished dataset. I am also particularly grateful to Y. Nishiaki (The University Museum of The University of Tokyo,) who gave me access to the collections of The University Museum as a part of a postdoctoral fellowship funded by the Japan Society for the Promotion of Science (JSPS). My thanks go also to colleagues from The University Museum of The University of Tokyo, C. Akashi, T. Odaka and especially S. Kadowaki (Nagoya University) for his remarks and our lively exchanges about this subject. I am grateful to M. Jalabadze (Georgian National Museum, Georgia) and to F. Guliyev (Institute of Archaeology and Ethnography, the National Academy of Science, Azerbaijan), for their support during fieldwork. My deep gratitude is also extended to the members of the Azerbaijani-French research group at Mentesh Tepe and Kiçik Tepe, and the Georgian-French research team at Gadachrili Gora for their supports during fieldwork and the subsequent research. I would also like to thank B. Lyonnet, C. Hamon, G. Palumbi, Y. Nishiaki, S. Kadowaki for their help in correcting this article, as well as the anonymous reviewers who helped me to clarify the paper. Lastly, I am grateful to J.-J. Herr (research fellow in the Peshdar Plain Project, UMR 7041) whose "outsider" perspective led to fruitful debates on the more theoretical notions developed in this article.

E. Baudouin Chercheur associé, UMR 7041 Archéologie et Sciences de l'Antiquité Équipe VEPMO, Maison Archéologie et Ethnologie René-Ginouvès, 21 allée de l'Université, 92023 Nanterre cedex $-F_{\text {rance }}$ emmanuel.baudouin1@gmail.com

\section{BIBLIOGRAPHY}

\section{Abibullaev O.}

1959 Arkheologicheskiye raskopki v Kyul-Tepe [Archaeological excavations at Kyul Tepe]. Baku: s.n.

1963 Nekotorye itogi izuchenija kholma Kjul Tepe v Azerbajdzhane [Elements for the study of Kül Tepe. Archaeological researches in Azerbaijan]. Sovetskaja Arkheologija 3: 157-168.

Aliyev T. and Helwing B.

2009 Kamiltepe in der Milebene. Archaölogische Untersuchungen 2009. AMIT 41: 23-45.

20. BAUDOUIN E. (forthcoming), L'architecture en Syro-Mésopotamie et dans le Caucase de la fin $d u 7^{e}$ à la fin du $5^{e}$ millénaire. Turnhout: Brepols.
AMIRKhANOV K.A.

1987 Choskoe poselenie. Chelovek i ego kul'tura v mezolite i neolite gornogo Dagestana [The Chokh settlement. Men and culture in the Mesolithic and Neolithic of mountainous Dagestan]. Moscow: Nauka.

ARIMURA M., BADALYAN R., GASPARYAN B. and ChATAigner C. 2010 Current Neolithic research in Armenia. Neo-Lithics 1/10:77-85. AURENChE O.

(ed.) 1977 Dictionnaire illustré multilingue de l'architecture du ProcheOrient ancien. Lyon: Maison de l'Orient (Collection de la Maison de l'Orient méditerranéen ancien 3, Série archéologique 2). 
La maison orientale. L'architecture du Proche-Orient ancien des origines au milieu du quatrième millénaire. Paris: Librairie

P. Geuthner (Bibliothèque archéologique et historique 109).

Aurenche O., Klein A., Guillaud H. and Chazelles C.-A. de

2011 Essai de classification des modalités de mise en œuvre de la terre crue en parois verticales et de leur nomenclature. In: ChAzelles C.-A. de, Klein A. and Pousthomis N. (eds.), Les cultures constructives de la brique crue. Échanges transdisciplinaires sur les constructions en terre, placés sous la présidence du professeur Olivier Aurenche. Actes du colloque de Toulouse, 16-17 mai 2008: 13-34. Montpellier: Éditions de l’Espérou.

AzIMOv M.S.

2006 Architectural development in the earliest settled agricultural phases of Azerbaijan. Oxford: Archaeopress (BAR Int. Ser. 1467).

BADALYAN R. and HARUTYUNYAN A.

2014 Aknashen - The Late Neolithic settlement of the Ararat Valley: Main results and prospects for the research. In: GASPARIAN B. and ARImura M. (eds.), Stone Age of Armenia. A guide-book to the Stone Age Archeaology in the Republic of Armenia: 161-176. Kanazawa: Center for Cultural resource studies, Kanazawa University.

\section{Badalyan R., Lombard P., Avetisyan P. and Chataigner C.}

2004 The Neolithic and Chalcolithic phases in the Ararat Plain (Armenia): The view from Aratashen. In: SAGona A. (ed.), A view from the highlands. Archaeological studies in honour of Charles Burney: 399-420. Leuven, Dudley, MA: Peeters (Ancient Near Eastern Studies Suppl. 12).

Badalyan R., Lombard P., Avetisian P., Chataigner C., Chabot J., Vila E., Hovespyan R., Willcox G. and PEssin H.

2007 New data on the Late Prehistory of the Southern Caucasus. The excavations at Aratashen (Armenia): Preliminary report. In: LYoNNET B. (ed.), Les cultures du Caucase (VIe $-I I I^{e}$ millénaires avant notre ère). Leurs relations avec le Proche-Orient: 37-62. Paris: CNRS Éditions (Éditions Recherche sur les civilisations).

Badalyan R.S., Harutyunyan A.A., Chataigner C., Le Mort F., Chabot J., BRochIER J.-E., BALAsEscu A., RADU V. and HovsePYAN R.

2010 The settlement of Aknashen-Khatunarkh, a Neolithic site in the Ararat Plain (Armenia): Excavation results 2004-2009. $T \ddot{U B A}-A R$ 13: 187-220.

Batiuk S.D., Jalabadze M., Graham A., Koridze I., Abu Jayyad K., collab. SAVULOv C.

2017 The Gadachrili Gora regional archaeological project: 2016 preliminary report. Anatolica 43: 173-202.

BAUDOUIN E.

2017 Remarques préliminaires sur les techniques architecturales du Néolithique et du Chalcolithique à Mentesh Tepe (Azerbaïdjan). In: Helwing B., Aliyev T., Lyonnet B., Guliyev F., Hansen S. and MirTshulava G. (eds.). The Kura projects. New research on the Late Prehistory of the Southern Caucasus: 153-162. Berlin: Dietrich Reimer Verlag (Archäologie in Iran und Turan 16).

BAUdouin E., LYoNNET B. and HAMON C.

2018 Architectural techniques and cultural relationships between the Caucasus and Mesopotamia at the beginning of the sixth millennium BC. In: DouchÉ C. and PIchON F. (eds.), From the Caucasus to the Arabian Peninsula: Domestic spaces in the Neolithic: 49-84. Paris: Association Routes de l'Orient.
Baudouin E., Mura M. and Manel C.

2017 Mentesh Tepe (Azerbaïdjan) : résultats préliminaires de la campagne de fouille 2015. Routes de l'Orient 3: 41-52.

\section{BRÉNIQUET C.}

1996 La disparition de la culture de Halaf. Les origines de la culture d'Obeid dans le Nord de la Mésopotamie. Paris: Éditions Recherche sur les civilisations (Bibliothèque de la Délégation archéologique française en Iraq 9).

Burchuladze A.A., Gedevanishvili L.D. and ToGonidze G.I.

1976 Tbilisi Radiocarbon dates III. Radiocarbon 18,3: 355-361.

BuTomo S.V.

1965 Radiocarbon dating in the Soviet Union. Radiocarbon 7,1:223-228.

CAUVIN J.

1978 Les premiers villages de Syrie-Palestine du IXe au VII millénaire avant J.-C. Lyon: Maison de l'Orient (Collection de la Maison de l’Orient méditerranéen ancien 4, Série archéologique 3).

Chataigner C.

1995 La Transcaucasie au Néolithique et au Chalcolithique. Oxford: Tempus Reparatum (BAR Int. Ser. 624).

Chataigner C., Badalyan R. and Arimura M.

2014 The Neolithic of the Caucasus. Oxford Handbook Online: 1-25 [DOI: 10.1093/oxfordhb/9780199935413.013.13].

Chataigner C. and Gratuze B.

2013 New data on the exploitation of obsidian in the Southern Caucasus (Armenia, Georgia) and Eastern Turkey, part 2: Obsidian procurement from the Upper Paleolithic to the Late Bronze Age. Archeometry 56,1: 48-69.

Chazelles-Gazzal C.-A. de.

1997 Les maisons en terre de la Gaule méridionale. Montagnac: Monique Mergoil (Monographies Instrumentum 2).

ChAzelles C.-A. de and KLein A.

2003 Échanges transdisciplinaires sur les constructions en terre. Actes de la table-ronde de Montpellier 17-18 novembre 2001. Vol. I : Terre modelée, découpée ou coffrée : matériaux et modes de mise en cuvre. Montpellier: Éditions de l'Espérou.

\section{ChELIDZE L.M.}

1979 Orudiya truda eneoliticheskogo poseleniya Arukhlo I [Work tools from the Eneolithic settlement of Arukhlo I]. Materialy po Arkheologii Gruzzi i Kavkaza 7: 19-31.

ChUBinshvili T.N. and ChELIDZE L.M.

1978 K voprosu o nekotorykh opredeljajuschikh priznakakh rannezemledel' cheskoj kult'tury VI-IV tys. do n.e. [Issues and characterisation of the early settlement from $\mathrm{VI}^{\text {th }}$ to $\mathrm{IV}^{\text {th }}$ millennium BC]. Izvestija Akademii Nauk Gruzinskoj SSR 1: 1-66.

DAKER N.

1984 Contribution à l'étude de l'évolution de l'habitat bédouin en Syrie. In: AURENchE O., Nomades et sédentaires : perspectives ethnoarchéologiques: 51-79. Paris: Éditions Recherche sur les civilisations.

Delougaz P.

1933 Plano-convex bricks and the method of their employment. Chicago: University of Chicago Press (Studies in Ancient Oriental Civilization 7). 
DoLUKhanov P.M. and TimofEEv V.I.

1972 Absolyutnaya khronologiya neolita Evrazii [The absolute chronology of the Eurasian Neolithic], In: Problemy absolyutnogo datirovaniya $v$ arkheologii: 28-75. Moscow: Nauka.

DzhAPARIDZE O.M. and DzhAVAKhIshviLI A.I.

1969 Rezul'taty rabot KvemoKartlijskoj arkheologicheskoj ekspedisii (1967 g.) [Excavation results of the archaeological expedition in the Kvemo-Kartli Plain (campaign 1967)]. Arkheologischeskie Ekspeditisii Gosudarstvennogo Muzeja Gruzzi I: 19-26.

1971 Rezul'taty rabot KvemoKartlijskoj arkheologicheskoj ekspedisii (1968-1969 gg) [Excavation results of the archaeological expedition in the Kvemo-Kartli Plain (campaigns 1968-1969)]. Otchety Arkheologischeskikh Ekspeditisii Gosudarstvennogo Muzeia Gruzzi AN GSSR 2: 22-33.

DzhAVAKhIshvili A.I.

1973 Stroitel'noe delo i arkhitektura poselenij juzhnogo Kavkaza V-III tys. do n.e [Architecture on the settlements in South Caucasus $V^{\text {th }}$-III ${ }^{\text {rd }}$ mill. BC]. Tbilisi: Metsniereba.

DzhAVAKhIshviLi A.I. and DzhAPARIDZE O.

1975 Otchet Kvemo-Kartlijskoj arkheologicheskoj ekspeditsii (1965$1971 \mathrm{gg}$ ) [Report on Kvemo-Kartili archeaological expedition (1965/1971)]. Tbilisi: Metsniereba.

FLANNERY K.V.

2002 The origins of the village revisited: From nuclear to extend households. American Antiquity 67,3: 417-433.

FoREsT J.-D.

1996 Mésopotamie : l'apparition de l'État. VII - -III millénaires. Paris: Paris-Méditerranée.

GAsche H. and BIRchMEIER W.

1981 Contribution à l'étude de la voûte en brique crue. Akkadica 24:1-16.

GORIDZE A.D.

1979 Zhivoj relikt kul'turnoj pshenitsy. Izvestija Akademii Nauk Gruzinskoj SSR 99.

GRAhAM M.

1993 Settlement organisation and residential variability among the Rarámuri. In: CAMERoN C.M. and ToMKA S.A. (eds), Abandonment of settlements and regions. Ethnoarchaeological and archaeological approaches: 25-42. Cambridge: Cambridge University Press.

GULIYEV F. and Nishiaki Y.

2014 Excavations at the Neolithic Settlement of Göytepe, West Azerbajan 2010-2011. In: BieLIńSKI P., GAWLIKOwsKi M., KolIńSK R., ŁaWEcka D., SołtYSiaK A. and WYGNAńSKa Z. (eds.), Proceedings of the $8^{\text {th }}$ international congress on the Archaeology of the Ancient Near East, $30^{\text {th }}$ April-4 ${ }^{\text {th }}$ May 2012, University of Warsaw. Vol. II: Excavation and progress reports posters: 3-16. Wiesbaden: Harrassowitz Verlag.

Hamon C., Jalabadze M., Agapishvili T., Baudouin E., Koridze I. and MEsSAger E.

2016 Gadachrili Gora: A new Neolithic excavation within the Shulaveri group (Chramis Valley, Georgia). Quaternary International 395: 154-169.

Hansen S. and MirTsKhulava G.

2012 Part II: The Neolithic settlement of Aruchlo. Report on the excavations in 2009-2011. In: LYonNET B., GuLIYEv F., HELwING B.,
Aliyev T., Hansen S. and Mirtskhulava G. (eds.), Ancient Kura 2010-2011: The first two seasons of joint field work in the southern Caucasus. AMIT 44: 58-71.

Hansen S., MirTskhulava G., Bastert-LAmbrichs K., GöRsDorf J., Neumann D., UlLrich M., GaTsov I. and Nedelcheva P.

2007 Bericht über die Ausgrabungen in dem neolithischen Siedlungsügel Aruchlo I im Sommer 2007. AMIT 39: 1-30.

HANSEN S. and ULLRICh M.

2017 Report on the 2012-2014 excavation campaign in Aruchlo. In: Helwing B., Aliyev T., Lyonnet B., Guliyev F., Hansen S. and MirTshulava G. (eds.), The Kura projects. New research on the Late Prehistory of the Southern Caucasus: 201-222. Berlin: Dietrich Reimer Verlag (Archäologie in Iran und Turan 16).

Hayrapetyan A., Martirosyan-Olshansky K., Areshian G.E. and AvETISYAN P.

2014 Preliminary results of the 2012 excavations at the Late Neolithic settlement of Masis Blur. In: GASPARYAN B. and ARIMURA M. (eds.), Stone Age of Armenia. A guide-book to the Stone Age Archeaology in the Republic of Armenia: 177-190. Kanazawa: Center for Cultural Resource Studies, Kanazawa University.

Helwing B. and Aliyev T.

2012 Part I: Field work in the Mil Plain: The 2010-2011 expedition. In: Lyonnet B., Guliyev F., Helwing B., Aliyev T., Hansen S. and MirTskhulava G. (eds.), Ancient Kura 2010-2011: The first two seasons of joint field work in the southern Caucasus. AMIT 44: 4-17.

2017 Excavations in the Mil Plain sites, 2012-2014. In: HelwiNG B., Aliyev T., Lyonnet B., Guliyev F., Hansen S. and MirTshulaVa G. (eds.), The Kura projects. New research on the Late Prehistory of the Southern Caucasus: 11-42. Berlin: Dietrich Reimer Verlag (Archäologie in Iran und Turan 16).

Helwing B., Aliyev T., Lyonnet B., Guliyev F., Hansen S. and MirTshulaVa G. (eds.)

2017 The Kura projects. New research on the Late Prehistory of the Southern Caucasus. Berlin: Dietrich Reimer Verlag (Archäologie in Iran und Turan 16).

Houben H. and GuILlaud H.

1989 Traité de construction en terre. Marseille: Éditions Parenthèses.

Houben H., Guillaud H. and Dayre M.

2006 Traité de construction en terre. Marseille: Éditions Parenthèses (1 $1^{\text {st }}$ d. 1989).

IESSEN A.

1965 Iz istoricheskogo proshlogo Milsko-Karabakhskoj stepy [From the historical past of the Mil-Karabakh steppe]. Materialy $i$ Issledovanija po Arkheologii SSSR 125: 10-36.

IOSELIANI $\mathrm{V}$.

2017a Architecture debris from the burnt layers. In: HELwiNg B., Aliyev T., Lyonnet B., Guliyev F., HANSEN S. and MirTshulava G. (eds.), The Kura projects. New research on the Late Prehistory of the Southern Caucasus: 281-286. Berlin: Dietrich Reimer Verlag (Archäologie in Iran und Turan 16).

2017b Ditches at Aruchlo and other Shomu-Shulaveri sites. In: Helwing B., Aliyev T., Lyonnet B., Guliyev F., Hansen S. and MirTshulaVA G. (eds.), The Kura projects. New research on the Late Prehistory of the Southern Caucasus: 223-232. Berlin: Dietrich Reimer Verlag (Archäologie in Iran und Turan 16). 
Kadowaki S., Maher L., Portillo M., Albert R.M., Akashi C., GULIYEV F. and NIshIAKI Y.

2015 Geoarchaeological and paleobotanical evidence for prehistoric cereal storage in the southern Caucasus: The Neolithic settlement of Göytepe (mid $8^{\text {th }}$ millennium BP). Journal of Archaeological Science 53: 408-425.

Kiguradze T.

1976 Aghmosavlet amierkavkasiis adresamitsatmokmedo kulturis periodiatsia [The periodization of the Early Farming culture of the Western Transcaucasia]. Tbilisi: Mestniereba.

1986 Neolithische Siedlungen von Kvemo-Kartili, Georgien. München: Beck.

KushNAREVA K.K.

1997 The southern Caucasus in Prehistory: Stages of cultural and socioeconomic development from the eighth to the second millennium BC. Philadelphia: University of Philadelphia (University Museum Monograph 99).

LE BRUN A.

1989 Le Néolithique de Chypre et sa relation avec le PPNB du Levant. Paléorient 15,1: 161-167.

LERoI-Gourhan A.

1945 Évolution et techniques. Vol. 2 : Milieu et techniques. Paris: Albin Michel (Sciences d'aujourd'hui).

LIBERSKI-BAGNOUD D.

2002 Les dieux du territoire : penser autrement la généalogie. Paris: Éditions de la MSH-CNRS Éditions.

LINICK T.W.

1977 La Jolla radiocarbon measurments VII. Radiocarbon 19: 19-48.

LOMBARD P. and ChATAIGNER C.

2004 Le Néolithique et le Chalcolithique en Transcaucasie : l'exemple des bassins de la Kura et de l'Araxe. In: Guilaine J. (ed.), Aux marges des grands foyers du Néolithique. Périphéries débitrices ou créatrices: 61-84. Paris: Errance (Séminaires du Collège de France).

LyonNet B., Guliyev F., collab. BAUdouin E., Bouquet L., BRULEYChabot G., Samzun A., Fontugne M., Degorre E., Husson X. and RAYMOND P.

2017 Mentesh Tepe (Azerbaijan), a preliminary report on the 2012-2014 excavations. In: Helwing B., Aliyev T., Lyonnet B., Guliyev F., HANSEN S. and MirTshulava G. (eds.), The Kura projects. New research on the Late Prehistory of the Southern Caucasus: 125-140. Berlin: Dietrich Reimer Verlag (Archäologie in Iran und Turan 16).

Lyonnet B., Guliyev F., collab. Bouguet L., Bruley-Chabot G., FonTUGNE M., RAYMOND P. and SAMZUN A.

2012 Mentesh Tepe. In: Lyonnet B., Guliyev F., Helwing B., Aliyev T., Hansen S. and Mirtskhulava G. (eds.), Ancient Kura 2010-2011: The first two seasons of joint field work in the southern Caucasus. AMIT 44: 86-97.

Lyonnet B., Guliyev F., Bouguet L., Bruley-Chabot G., SAmzun A., Pecqueur L., Jovenet E., Baudouin E., Fontugne M., Raymond P., Degorre E., Astruc L., Guilbeau D., Le Dosseur G., Benecke N., Hamon C., Poulmarc'h M. and Courcier A.

2016 Mentesh Tepe, an early settlement of the Shomu-Shulaveri culture in Azerbaijan. Quaternary International 395: 170-183.
MAHMUDov F.R.

1984 Oliköməktəpəsində arxeoloji qazıntılann ilkin yekunlan: Azarbaycanda daş dövrü va eneolit [Preliminary results of the Archaeological reseach at Alikemektepesi]. Baki: s.n.

MARGUERON J.-C.

1985 Notes d'archéologie et d'architecture orientales 4. - Propos sur le sillon destructeur (étude de cas). Syria 62,1-2: 1-20.

1987 Notes complémentaires sur la question de l'étage. In: HUot J.-L. (ed.), Préhistoire de la Mésopotamie : la Mésopotamie préhistorique et l'exploration récente du djebel Hamrin: 447-460. Paris: CNRS Éditions.

Martirosyan-Olshansky K., Areshian G.E., Avetisyan P. and HAYRAPETYAN A.

2013 Masis Blur: A Late Neolithic settlement in the Plain of Ararat, Armenia. Backdirt 12: 142-146.

MeILlassoux C.

1975 Femmes, greniers et capitaux. Paris: Éditions Maspero.

Menabde M., Kiguradze T. and Gogadze K.M.

1978 Rezultaty rabot Kvemo-Kartlijskoj ekspeditsii (1976-1977 gg.) [Results of the Kvemo-Kartli archaeological expedition (19761977)]. Arkheologischeskie Ekspeditisii Gosudarstvennogo Muzeja Gruzzi 6: 27-45.

1980 Rezultaty rabot Kvemo-Kartlijskoj ekspeditsii (1978-1979 gg.) [Results of the Kvemo-Kartli archaeological expedition (19781979)]. Arkheologischeskie Ekspeditisii Gosudarstvennogo Muzeja Gruzzi 7: 19-33.

Monge P. and MARQUis P.

2008 Dictionnaire de l'Archéologie. Paris: Larousse (In Extenso).

NARIMANOV I.G.

1977 K istorii drevnejshego skotovodstva Zakavkaz'ja. Doklady Akademii Nauk Azerbaidzhanskoj SSR 10: 56-58.

1986 Raskopki eneoliticheskikh poselenij v Azerbajdzhane [Excavations of the Eneolithic settlement In Azerbaijan]. Arkheologischeskie Otkrytija 1984g.: 423.

1987 Kul'tura drevneyshego zemledel'chesko-skotovocheskogo naseleniya Azerbadzhana, epokho eneolita VI-IV tys. do n.e. [The culture of the earliest farmers and herders in Azerbaijan, Chalcolithic period $6^{\text {th }}-4^{\text {th }}$ millenia BC]. Baku: Elm.

1992 The earliest agricultural settlements in the territory of Azerbaidzhan. Soviet Anthropology and Archeology 4,30: 9-66.

NIEBIERIDZE L.

1978 Darkvetis Mravalpeniani Ekhi [The rock-shelter of Darkveti]. Tbilisi: Metsniereba.

NishIAKI Y., GULIYEV F. and KADowAKI S.

2015a Chronological contexts of the Earliest Pottery Neolithic in the South Caucasus: Radiocarbon dates for Göytepe and Hacı Elamxanl1 Tepe, Azerbaijan. American Journal of Archaeology 119,3: 279-294.

Nishiaki Y., Guliyev F., Kadowaki S., Alakbarov V., Miki T., SAlimbaYov S., AKashi C. and ARAI S.

2015b Investigating cultural and socioeconomic change at the beginning of the Pottery Neolithic in the Southern Caucasus: The 2013 excavations at Hac1 Elamxanlı Tepe, Azerbaijan. BASOR 374:1-28. 
Nishiaki Y., GUliYeV F., KadowaKi S., ARimatsu Y., HaYaKaWa Y., Shimogama K., Miki T., Akashi C., Arai S. and Salimbeyov S.

2013 Hacı Elamxanlı Tepe: Excavations of the earliest Pottery Neolithic occupations on the Middle Kura, Azerbaijan, 2012 AMIT 45: 1-25.

NishiaKi Y., GULIYEV F., KADowAKI S. and OMORI T.

2018 Neolithic residential patterns in the southern Caucasus: Radiocarbon analysis of rebuilding cycles of mudbricks architecture at Göytepe, west Azerbaijan. Quaternary International 474B: 119-130.

Ollivier V., Fontugne M., LyonNET B. and Chataigner C.

2016 Base level changes, river avulsions and Holocene human settlement dynamics in the Caspian Sea area (middle Kura valley, South Caucasus). Quaternary International 395: 79-94.

PÉRouse DE MonTcLos J.-M.

2004 Architecture : méthode et vocabulaire. Paris: Éditions du Patrimoine. PoLlock S

2013 Defining a Halaf tradition: The construction and use of space. In: Nieuwenhuyse O., Bernbeck R., AKkeRmans P.M.M.G. and RoGAsch J. (eds.), Interpreting the Late Neolithic of Upper Mesopotamia: 171-181. Turnhout: Brepols (Papers on Archaeology from The Leiden Museum of Antiquities 9).

Ricci A., D’Anna M.B., Lawrence D., Helwing B. and Aliyev T.

2018 Human mobility and early sedentism: The Late Neolithic landscape of southern Azerbaijan. Antiquity 92,366: 1445-1461.

Roux J.-C. and CAmmas C.

2010 Les techniques constructives en bauge dans l'architecture protohistorique de Latarra (milieu du v $v^{e}-$ milieu du $\mathrm{IV}^{\mathrm{e}} \mathrm{s}$. av. n.è.). Lattara 21,1: 219-288.

SAGONA A.

1993 Settlement and society in Late Prehistoric Trans-Caucasus. In: FrangiPANE M., HAUPTMANN H., LiVERANi M., MATThiaE P. and MELLINK M. (eds.), Between the rivers and over the Mountains. Archaeologica Anatolica et Mesopotamica Alba Palmieri dedicate: 453-474. Rome: Universtà di Roma "La Sapienza".

2018 The Archaeology of the Caucasus: From earliest settlements to the Iron Age. New York: Cambridge University Press (Cambridge World Archaeology).
SAUVAGE M.

1998 La brique et sa mise en œuvre en Mésopotamie : des origines à l'époque achéménide. Paris: Ministère des Affaires étrangères (Éditions Recherche sur les civilisations).

2001 Les briques de grande taille à empreintes de doigts : le Choga Mami Transitional et la culture de Oueili. In: BRÉNIQUET C. and KePINsKi C. (eds.), Études mésopotamiennes : recueil de textes à Jean-Louis Huot. Paris : Éditions Recherches sur les civilisations.

2009 Les débuts de l'architecture de terre au Proche-Orient. In: Achenza M., CoRella M. and Guillaud H. (eds.), Mediterra 2009. $1^{a}$ conferenza mediterranea sull'architettura in terra cruda: 189-198. Monfalcone: EdicomEdizioni.

STORDEUR D.

2015 Le village de Jerf el Ahmar (Syrie, 9500-8700 av. J.-C). L'architecture, miroir d'une société néolithique complète. Paris: CNRS Éditions.

Thoumin R.

1936 Le Ghab. Revue de géographie alpine 24,3: 467-538.

TOROSJAN R.

1976 Rannezemledel'cheskoe poselenie Tekhuta [The early agricultural settlement of Tekhut]. Erevan: Akademija Nauk Armjanskoj SSR (Arkheologicheskie Raskopki v Armenii 14).

TuNcA Ö.

1984 L'architecture religieuse protodynastique en Mésopotamie. Louvain: Peeters (Akkadica Suppl. 2).

VOIGT M.

1983 Hajji Firuz Tepe, Iran: The Neolithic settlement. Philadelphia: University of Philadelphia (Hasanlu Excavation Reports 1; University Museum Monograph 50).

WhIThING J.W. and AYREs B

1968 Inferences from the shape of dwellings. In: CHANG K. (ed.), Settlement Arachaeology: 117-133. Palo Alto: National Press Books.

\section{WuLff H.E.}

1966 The traditional crafts of Persia: Their development, technology, and influence on Eastern and Western civilizations. Cambridge (Mass.): The M.I.T. Press. 